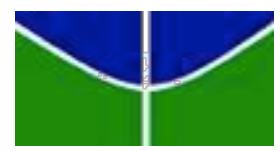

Universidade de Brasília

Instituto de Relações Internacionais

Programa de Pós-Graduação em Relações Internacionais

Mírian Campos Moraes e Silva

O COMÉRCIO INTERNACIONAL E O PAPEL DAS INSTITUIÇÕES:

UMA ANÁLISE PARA O BRASIL 
Mírian Campos Moraes e Silva

\section{O COMÉRCIO INTERNACIONAL E O PAPEL DAS INSTITUIÇÕES: UMA ANÁLISE PARA O BRASIL}

Dissertação apresentada ao Programa de PósGraduação em Relações Internacionais, Instituto de Relações Internacionais da Universidade de Brasília como parte dos requisitos para obtenção do grau de Mestre em Relações Internacionais. Área de Concentração: Política Internacional e Comparada.

Orientador: Prof. Dr. Eiiti Sato. 
Aos meus pais, irmãos e esposo, pelo apoio constante e incondicional. 


\section{AGRADECIMENTOS}

Agradeço, em primeiro lugar, a todos os familiares e amigos, que foram compreensivos com as rotinas de estudo e com o tempo de dedicação impostos por este trabalho.

Agradeço também a todos os colegas do MDIC, que ofereceram importantes colaborações técnicas para a elaboração do trabalho, e que continuam a contribuir, dia a dia, para o meu crescimento pessoal e profissional.

Agradeço a todos os professores do IREL e aos colegas de pós graduação, sem os quais a jornada até aqui não teria sido possível.

Agradeço, em especial, ao Professor Eiiti Sato, que, com as nossas longas conversas, propiciou mais do que orientação para a dissertação, instigando reflexões que serão levadas para a vida. 
"It is polities that shape economic performance because they define and enforce the economic rules of the game."

(Douglas North) 


\section{RESUMO}

O presente trabalho aborda a relação entre instituições e comércio internacional, fazendo uma análise de três aspectos institucionais considerados de extrema relevância para o desenvolvimento do comércio exterior brasileiro na atualidade: as tarifas, os tributos e o crédito público à exportação. Mas, para permitir a compreensão das instituições atuais, é necessário voltar atrás e observar a evolução do quadro institucional e da política comercial brasileira no passado recente, além de verificar em que medida a autonomia do governo brasileiro na construção das instituições é limitada ou orientada pelas instituições internacionais. A dissertação será composta por quatro capítulos: o primeiro, apresentando o referencial teórico e delimitando os conceitos que serão adotados; o segundo, fazendo uma breve retrospectiva histórica sobre o desenvolvimento das instituições domésticas relativas ao comércio exterior; o terceiro, tratando da evolução do regime internacional de comércio, em nível multilateral de regional; e o quarto, analisando a configuração atual das tarifas, dos tributos e dos créditos, a relação que mantêm com instituições do regime internacional e seus efeitos sobre a atividade comercial. Como se verificará, apesar dos avanços institucionais referentes ao comércio exterior que o Brasil alcançou no século $X X$, ainda são muitas as dificuldades normativas e operacionais a serem superadas, tanto no plano doméstico quanto no plano internacional, sobretudo no Mercosul. Para isso, é importante o governo estar consciente de seu papel como orientador da atividade econômica, por meio da construção das instituições.

Palavras-chave: instituições, comércio internacional, governo, OMC, MERCOSUL, tarifas, tributos, crédito às exportações. 


\begin{abstract}
This dissertation discusses the relationship between institutions and international trade, based on the analysis of three core institutional aspects for the development of Brazil's foreign trade nowadays: tariffs, taxes and public export credit. So to understand the current institutions, it is important to look back to the evolution of the Brazilian institutional framework and trade policy in the recent past, observing the limitations imposed by international institutions on the government autonomy on this issues. The thesis is composed by four chapters: the first one exposes the theoretical framework and the main concepts adopted; the second one presents a brief retrospective on the development of domestic institutions regarding foreign trade; the third one explores the evolution of the international trade regime in its multilateral and regional aspects; and the last one analyses the current arrangement of tariffs, taxes and export credits in Brazil, considering its interrelationship with international institutions and its impacts on trade. At the end, despite Brazil's institutional progress during the last century, we found that important regulatory and operational obstacles still persist, both in domestic and international arenas. To overcome this issues, it is crucial that the government is aware of its role in guiding economic activity through institutions.
\end{abstract}

Keywords: institutions, international trade, government, WTO, MERCOSUR, tariffs, taxes, export credit. 


\section{LISTA DE QUADROS}

Quadro 1 - Programas e ações de fomento à exportação durante o governo Cardoso 42 Quadro 2 - Programas e ações de fomento à exportação durante o governo Lula ...... 48

Quadro 3 - Programas e ações de fomento à exportação durante o primeiro mandato do governo Dilma Rousseff 54

Quadro 4 - Acordos estruturantes do sistema multilateral de comércio resultantes da

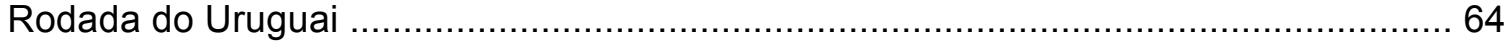

Quadro 5 - Rodadas de negociação no âmbito do GATT/1947 …............................ 70 


\section{LISTA DE GRÁFICOS}

Gráfico 1 - Desembolsos anuais do BNDES com financiamentos totais 104

Gráfico 2 - Desembolsos anuais do BNDES com financiamentos de grandes empresas 105

Gráfico 3 - Desembolsos anuais do BNDES com financiamentos de empresas médiagrandes (conforme classificação iniciada em 2010) 105

Gráfico 4 - Desembolsos anuais do BNDES com financiamentos de médias empresas 105

Gráfico 5 - Desembolsos anuais do BNDES com financiamentos de pequenas

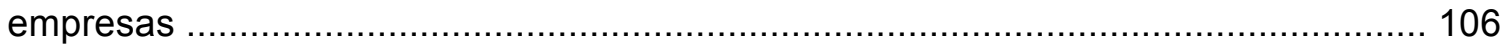

Gráfico 6 - Desembolsos anuais do BNDES com financiamentos de microempresas 106 


\section{LISTA DE ABREVIATURAS E SIGLAS}

ACC

APEX

ANATEL

ANTT

BB

BCB

BEFIEX

CACEX

Brasil

CAMEX

CCE

CEPAL

$\mathrm{CNI}$

COFINS

CONCEX

CPA

DECEX

$\mathrm{FHC}$

FINEX

GATT

II

ICM

ICMS

INMETRO

IPI

$|S|$
Adiantamento de Contrato de Câmbio

Agência de Promoção das Exportações

Agência Nacional de Telecomunicações

Agência Nacional de Transportes Terrestres

Banco do Brasil

Banco Central do Brasil

Comissão de Benefícios Fiscais e

Programas Especiais de Exportação

Carteira de Comércio Exterior do Banco do

Câmara de Comércio Exterior

Comissão de Comércio Exterior

Comissão Econômica para América Latina

e Caribe

Confederação Nacional da Indústria

Contribuição para o Financiamento da Seguridade Social

Conselho Nacional de Comércio Exterior

Conselho de Política Aduaneira

Departamento de Comércio Exterior

Fernando Henrique Cardoso

Fundo de Financiamento à Exportação

General Agreement on Tariffs and Trade

Imposto de Importação

Imposto sobre Circulação de Mercadorias

Imposto sobre Circulação de Mercadorias e Serviços

Instituto Nacional de Metrologia, Normalização e Qualidade Industrial Imposto sobre Produtos Industrializados Industrialização por Substituição de Importação 
MAPA

Abastecimento

MEFP

MERCOSUL

MDIC

MIC

MICT

MMA

MME

MPOG

MRE

OMC

PBM

PICE

PIS

PROEX

PSI

Reintegra

SISCOMEX
Ministério da Agricultura, Pecuária e

Ministério da Economia, Fazenda e Planejamento

Mercado Comum do Sul

Ministério do Desenvolvimento, Indústria e Comércio Exterior

Ministério da Indústria e Comércio

Ministério da Indústria, do Comércio e do Turismo

Ministério do Meio Ambiente

Ministério de Minas e Energia

Ministério do Planejamento, Orçamento e Gestão

Ministério das Relações Exteriores

Organização Mundial do Comércio

Plano Brasil Maior

Política Industrial e de Comércio Exterior

Contribuição para o Programa de Integração Social

Programa de Financiamento à Exportação

Processo de industrialização por substituição de importações

Regime Especial de Reintegração de Valores Tributários para Empresas Exportadoras

Sistema Integrado de Comércio Exterior 


\section{SUMÁRIO}

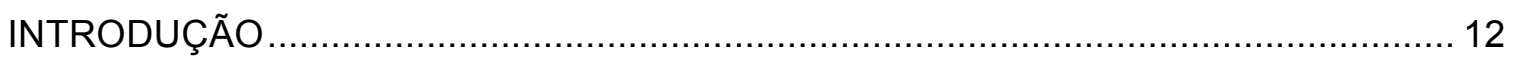

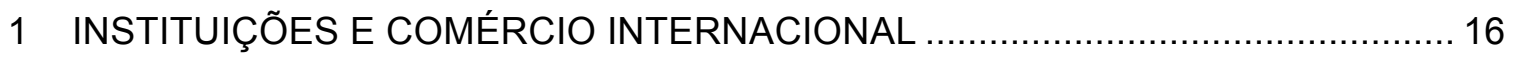

1.1 Breve histórico da economia institucional................................................... 16

1.2 O conceito de instituição e o papel do Estado ............................................... 18

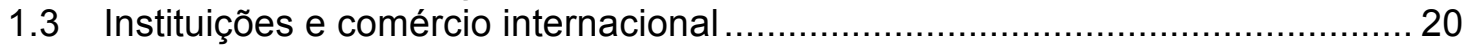

1.4 Qualidade das instituições e mudança institucional .................................... 22

2 A EVOLUÇÃO INSTITUCIONAL EM NÍVEL NACIONAL: A POLÍTICA COMERCIAL

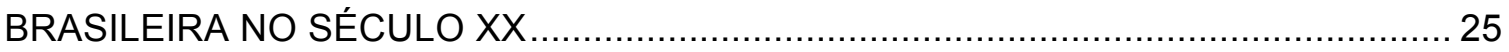

2.1 O viés protecionista da industrialização por substituição de importações na

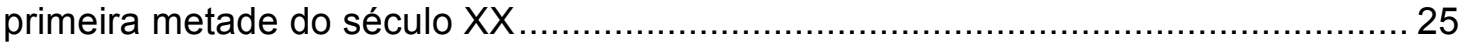

2.2 O período militar e as políticas de estímulo à exportação ............................... 27

2.3 Redemocratização, abertura e desmantelamento das políticas de estímulo à

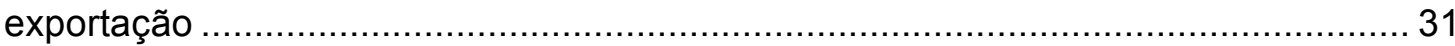

2.4 Estabilização econômica, tentativa de centralização da política comercial e retomada do apoio à exportação ..................................................................... 35

2.5 O governo PT e a conformação das características institucionais atuais ......... 44

2.6 O governo interino e as mudanças na governança do comércio exterior ..........55

3 A EVOLUÇÃO INSTITUCIONAL EM NÍVEL MUNDIAL: O REGIME

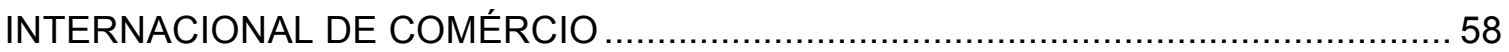

3.1 O sistema multilateral de comércio........................................................... 58

3.1.1 Histórico da formação do sistema multilateral de comércio......................... 58

3.1.2 Características gerais e principais marcos normativos do sistema

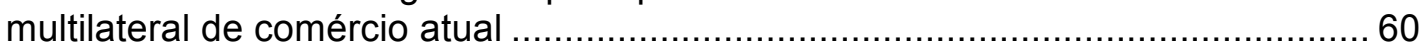

3.1.3 As rodadas de negociação e a evolução do escopo do sistema .................66

3.2 O comércio internacional e o regionalismo ............................................ 72

3.2.1 A relação entre regionalismo e sistema multilateral ............................... 72

3.2.2 A evolução dos acordos regionais de comércio na América do Sul: da

ALAC ao MERCOSUL ............................................................................... 75

3.2.3 As instâncias deliberativas do MERCOSUL e a criação das normativas

comerciais pelo bloco ............................................................................ 81

3.2.4 A condição de integração atual do MERCOSUL e a Tarifa Externa Comum

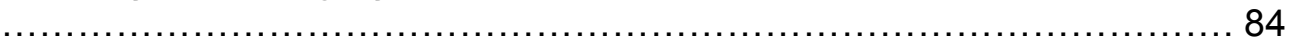

4 AS INSTITUIÇÕES E O COMÉRCIO EXTERIOR NO BRASIL ATUALMENTE ...... 89

4.1 Tarifas: a complexidade do regime internacional e seus impactos para a política

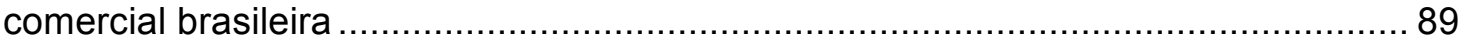

4.2 Tributação doméstica: os resíduos tributários e seus impactos sobre a indústria

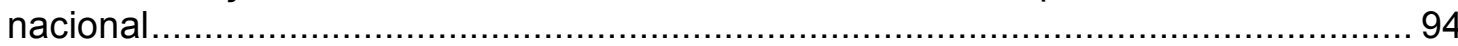

4.3 Financiamento e garantia: o funcionamento dos instrumentos de crédito público

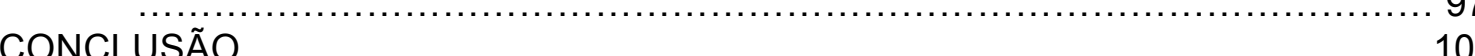

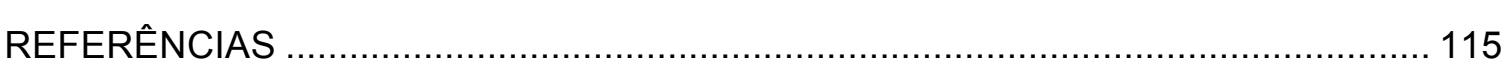




\section{INTRODUÇÃO}

É indiscutível que o comércio internacional tem um papel fundamental no crescimento e no desenvolvimento econômico dos países: do ponto de vista macroeconômico, os fluxos de comércio constituem um dos principais componentes de um balanço de pagamentos; sob a ótica microeconômica, afetam diretamente a oferta interna de bens e ampliam os mercados para as indústrias exportadoras, impactando os níveis de bem-estar das sociedades.

Em princípio, o objetivo de comércio exterior dos países é manter-se equilibrado, mas, na realidade, todo país procura exportar mais do que importar e apresentar saldos positivos em sua balança comercial, o que representa um resultado favorável para os produtores nacionais e o ingresso líquido de divisas para o país. No entanto, o sucesso de um país no comércio internacional está relacionado não apenas a seus resultados quantitativos, mas também, e sobretudo, a seus aspectos qualitativos. Países predominantemente exportadores de produtos primários, além de enfrentarem uma relação desfavorável em termos de valor agregado entre produtos exportados e importados, estão sempre sujeitos às volatilidades do preço internacional das commodities. Logo, a diversificação da pauta exportadora, com a inclusão de mercadorias industriais de maior valor agregado, é um objetivo geralmente perseguido pelos países.

Mas quais são os fatores que levam os países a comercializar mais ou menos com parceiros externos? O que determina as características da pauta exportadora de um país? Qual o papel do Estado nesse processo? Essas perguntas estão longe de ser triviais e há séculos economistas e cientistas sociais vêm trabalhando nessas investigações.

Inicialmente, os teóricos clássicos, notadamente Adam Smith e David Ricardo, tentaram explicar os fluxos comerciais com base nas vantagens absolutas $e$ comparativas de se produzir determinada mercadoria, mas o modelo baseava-se nas diferenças de produtividade de um único fator de produção, a mão de obra. A teoria neoclássica de Heckscher-Ohlin, também denominada teoria da dotação de fatores, representou um avanço da teoria clássica ao incorporar um segundo fator de produção - a terra -, procurando explicar o comércio com base na diferença de proporção entre os fatores terra e mão de obra dos países. A teoria neoclássica, no entanto, ainda não era capaz de explicar o comércio entre países com dotações de recursos semelhantes. 
Assim, novas teorias de comércio internacional passaram a buscar explicação para esse fenômeno. Paul Krugman e Staffan Linder, dois dos economistas de maior destaque dessa linha, tratam da ocorrência de comércio intra-indústria entre países de dotações de fatores semelhantes; mas, enquanto Krugman foca nos ganhos de escala, Linder embasa sua teoria nas diferenças de gostos dos consumidores.

O que essas teorias têm em comum? Todas elas buscam identificar a causa primordial que dá origem ao comércio entre os países. No entanto, muitos outros fatores influenciam nos tipos de mercadorias e nos volumes comercializados por um país, fatores que vão muito além da capacidade explicativa desses modelos teóricos. Conforme afirmou Coase (1999): "Economics, over the years, has become more and more abstract and divorced from events in the real world. Economists, by and large, do not study the workings of the actual economic system. They theorize about it".

Ao observar a realidade, não é difícil constatar os inúmeros aspectos burocráticos, logísticos, financeiros, de infraestrutura e, até mesmo, culturais que impactam quantitativa e qualitativamente as transações comerciais internacionais. Nesse sentido, Faucher e Niosi (1990, p. 92) atestam a incapacidade das teorias tradicionais do comércio internacional de explicar as relações comerciais e apontam a ausência da variável estatal como uma falha desses modelos:

(...) o atual quadro de referência em que é formulada a teoria do comércio limita fundamentalmente a capacidade de essa teoria contribuir para a compreensão e formação de nosso meio econômico internacional. O papel do Estado e da política estatal na modificação da disponibilidade de fatores e na formação do contexto institucional, em que ocorrem tanto o comércio internacional quanto a produção nacional de fatores, deve ser não somente reconhecido, mas incorporado como uma parte central da teoria.

A nosso ver, a Economia Institucional apresenta-se como a opção teórica capaz de superar essa deficiência dos outros referenciais teóricos. Trata-se ela da vertente da teoria econômica que reconhece o papel das instituições - compreendidas como normas formais e informais que orientam o comportamento do agentes - na determinação das relações econômicas. Sob seu amparo, é possível estabelecer a relação do Estado com o desenvolvimento do comércio internacional, por meio do estabelecimento das normas que afetam as atividades de produção e comercialização como a fixação de tarifas e tributos, o fornecimento de crédito, a normatização técnica dos produtos, a fixação dos procedimentos aduaneiros etc. 
Partindo do embasamento teórico da Economia Institucional, este trabalho buscará analisar alguns aspectos institucionais decorrentes da atuação do Estado brasileiro que se constituem em variáveis relevantes para o desenvolvimento das relações comerciais do Brasil na atualidade. $O$ trabalho caracteriza-se fundamentalmente como um estudo de caso, no qual serão apresentadas as origens e as características do quadro institucional do comércio exterior brasileiro, a fim de possibilitar a realização de inferências e formulação de hipóteses sobre o impacto dessas instituições para o desempenho das relações comerciais do país.

No primeiro capítulo, apresentaremos um breve histórico do desenvolvimento desta corrente teórica e faremos a delimitação do conceito de instituição que será adotado no trabalho, buscando demonstrar que, dentro dessa perspectiva, o Estado é um ator fundamental na constituição das instituições. A partir disso, buscaremos explicar a relação que instituições e comércio internacional, que definidos sob as óticas doméstica e internacional, para então apresentar breves considerações sobre o caráter histórico da formação institucional.

Levando em consideração a importância dessa perspectiva histórica, trataremos nos capítulos dois e três, respectivamente, do processo de constituição das instituições no âmbito interno e no plano internacional. No capítulo dois, discorreremos sobre a evolução normativa e das burocracias estatais relevantes para o comércio brasileiro ao longo do século $\mathrm{XX}$, destacando as principais características do arcabouço institucional em cada período de governo. No capítulo seguinte, trataremos da constituição do regime internacional de comércio sob as óticas do sistemas multilateral, representado principalmente pela $\mathrm{OMC}$, e do sistema regional latino-americano, no qual o Brasil se insere por meio da ALADI e do MERCOSUL. Nessa parte, procuraremos destacar os aspectos normativos da OMC e do MERCOSUL que condicionam a normatização do comércio exterior no Brasil e restringem a autonomia do Estado brasileiro para a formulação de políticas de comércio exterior.

Por fim, no capítulo quatro, faremos uma análise um pouco mais detalhada das características e das dificuldades envolvidas nas instituições relevantes para o comércio exterior brasileiro atualmente. Não sendo possível examinar todos os aspectos institucionais que de alguma forma influenciam nas relações comerciais do Brasil, em vista da limitação de tempo para realização desta pesquisa, optamos por um recorte que compreenda os aspectos mais tradicionais de ação do governo para fins de fomento do comércio exterior: as tarifas, os tributos e o crédito público para as 
exportações. Serão apresentadas suas principais características normativas e operacionais, os aspectos de inter-relação mantidos com as instituições de comércio internacional - tanto da OMC quanto do MERCOSUL - e as principais dificuldades enfrentadas no seu funcionamento atualmente.

Pretendemos, com este trabalho, chamar atenção para o papel das instituições no desenvolvimento do comércio internacional e elaborar um diagnóstico de algumas instituições relevantes para o comércio exterior brasileiro, atentando para a importância do Estado na sua construção, mas lembrando das limitações impostas pelo regime internacional de comércio. 


\section{INSTITUIÇÕES E COMÉRCIO INTERNACIONAL}

O objetivo deste capítulo é apresentar os fundamentos teóricos que baseiam a análise do objeto principal do trabalho, ou seja, a relação entre instituições e comércio exterior no Brasil na atualidade. Considerando que o referencial teórico tem caráter apenas instrumental, não cabe esgotar os conceitos e as discussões por trás da economia institucional, cuja literatura é bastante extensa e, muitas vezes, controversa. Por isso, serão apresentados apenas os conceitos considerados mais relevantes a respeito de instituição, sua relação com o objeto de estudo (o comércio) e as características do processo de construção e mudança institucional.

\subsection{Breve histórico da economia institucional}

A economia institucional está inserida no campo da economia do desenvolvimento ${ }^{1}$, a qual busca compreender os fatores determinantes do processo de crescimento e desenvolvimento econômico das nações. Nesse contexto, o institucionalismo surgiu como uma crítica às teorias neoclássicas do crescimento ${ }^{2}$ (JAMESON, 2008, p. 164), reconhecendo a endogeneidade de elementos cruciais ao desenvolvimento e resgatando os métodos histórico e indutivo de análise dos casos concretos.

A origem do institucionalismo encontra-se no trabalho de Thorstein Veblen, com o livro The theory of the leisure class, de 1899. No entanto, apenas no pós Segunda Guerra Mundial a economia institucional ganharia corpo teórico, juntamente com a emergência da própria teoria do desenvolvimento econômico (ver Apêndice A). A tese central de Veblen era de que o desenvolvimento de longo-prazo encontra restrições na rigidez cultural e nos hábitos resistentes de determinados grupos sociais (JAMESON, 2008 , p. 164), em um modelo de sociedade industrial que mantêm a estratificação

\footnotetext{
1 Ver Apêndice A, contendo resumo sobre a evolução teórica da economia do crescimento e do desenvolvimento.

${ }^{2}$ A teria neoclássica do crescimento é a denominação atribuída a um conjunto de modelos construídos a partir dos fundamentos da economia neoclássica, sendo o mais conhecido deles o modelo de Solow (ver SOLOW, 1956). A ênfase desses modelos recai sobre a possibilidade de substituição entre os fatores de produção trabalho e capital, de modo a permitir um crescimento contínuo e estável, enquanto progresso técnico é considerado um fator exógeno (ver SANDRONI, 2002, p.600).
} 
oriunda do feudalismo e na qual as ocupações dos indivíduos não tem necessariamente relação com o critério de utilidade econômica (ver VEBLEN, 1889).

Futuramente, o trabalho de Veblen teve grande influência sobre a formulação das premissas conceituais e metodológicas da teoria institucional propriamente. Jameson (2008) afirma que três escolas norte-americanas se destacam nesse processo. Em primeiro lugar, a Escola de Wisconsin, cujo expoente foi John R. Commons, colocou em evidência o papel do governo como guia do processo de mudança e como responsável por encontrar mecanismos institucionais para superar os focos de resistência social. Em seguida, a Escola do Texas, com destaque para Clarence Ayres, contribuiu com o detalhamento dos fatores sociais que poderiam impor resistência às mudanças tecnológicas. Por fim, a Escola de Columbia, com Wesley Clair Mitchell, formulou a proposta metodológica fundamental da escola, substituindo o método dedutivo pelo indutivo e fazendo uso de investigações empíricas, em vez da construção de modelos.

O institucionalismo, portanto, foi originalmente concebido como uma teoria de desenvolvimento econômico que parte da análise histórica e do método indutivo para investigar as causas do desenvolvimento das nações, considerando as instituições como fator limitante ou meio de incentivo da atividade econômica, e destacando o papel do Estado no processo de mudança institucional. A essência dessa visão pode ser sintetizada nas palavras de North (1995, pp. 1-2):

In fact, to put it bluntly, the growth theory stemming from neo-classical economics, old or new, suggests not only ignorance of the empirical evidence, historical or contemporary, but a failure to recognize that incentives matter; surely a remarkable position for economists whose theory is built around incentives. It is the incentive structure imbedded in the institutional/organizational structure of economies that has to be a key to unraveling the puzzle of uneven and erratic growth.

A economia do desenvolvimento e a teoria institucional, nesses termos, passaram por um período de ascensão até a década de 1980. A partir de então, em decorrência do ressurgimento da ortodoxia econômica, o institucionalismo sofreria uma reformulação.

A doutrina neoliberal, que passou a prevalecer no pensamento econômico, preconizou a expansão das relações de mercado em detrimento da atuação do Estado, a eliminação dos controles de preços e das limitações às taxas de juros, o fim da interferência no mercado de trabalho, entre outras medidas de governo minimalista. Seu 
argumento era de que eficiência proporcionada pela livre alocação dos recursos impulsionaria o crescimento e o desenvolvimento econômico.

Nesse contexto, surgiu a Nova Economia Institucional (NEI), que representou uma adaptação dos preceitos da economia institucional tradicional a fundamentos teóricos e metodológicos neoclássicos. A NEl assumiu os pressupostos do individualismo e da escolha racional, em oposição à visão original de interação entre indivíduos e instituições, e concentrou-se nas instituições relacionadas ao mercado e à propriedade privada. Além disso, a NEI valorizou o instrumental metodológico ortodoxo, como a formulação de modelos e a utilização de métodos quantitativos, na tentativa de avaliar o impacto econômico das instituições ${ }^{3}$. Contudo, mais recentemente, novos trabalhos voltaram a privilegiar o enfoque original da economia institucional, utilizando o método histórico e a tratando instituições de maneira mais abrangente e holística 4 .

\subsection{O conceito de instituição e o papel do Estado}

North definiu instituições como os meios de coação, formais ou informais, que orientam as relações políticas, econômicas e sociais de uma determinada sociedade (NORTH, 1991, p. 97). Conforme afirmou, em palestra proferida por ocasião do prêmio Nobel de Economia em 1993, "institutions form the incentive structure of a society and the political and economic institutions, in consequence, are the underlying determinant of economic performance. (...) Institutions are the humanly devised constraints that structure human interaction" (NORT, 1993).

Dentro dessa concepção, os meios formais de coação correspondem às normais legais impostas pelo Estado, enquanto os informais são formados pelo conjunto de crenças, costumes e tradições que indivíduos e grupos observam dentro de uma

3 Pode-se apontar o trabalho de Ronald Coase, ("The problem of social cost", 1960) como uma importante influência para os economistas dessa escola, dentre os quais se destacam Oliver Williamson ("The economic isntitutions of capitalism", 1985) e Douglas North ("Institutions, institutional change and economic performance", 1990; "Understanding the process of economic change", 2005).

4 Um exemplo de trabalho sob essa nova ótica é o do economista sul-coreano Ha-Joon Chang, que retomou a crítica institucional às teorias do mainstream do desenvolvimento econômico. Seu trabalho é baseado na análise empírica e privilegia a utilização do método indutivo, afirmando a importância do Estado e das decisões políticas na definição e na qualidade das instituições (CHANG, 2002/2004; CHANG e EVANS, 2005). 
sociedade (NORTH, 1991, 1993). As instituições, portanto, são as "regras do jogo" das relações políticas, econômicas e sociais. Cabe destacar que as instituições não se confundem com as entidades organizadas que compõem a sociedade (como governos, partidos, empresas, sindicatos, igrejas etc.) (HARBER, 2000).

$\operatorname{North}^{5}$ (2003, p. 1) explica que as instituições existem para reduzir as incertezas no mundo - elas constituem o sistema de incentivos que orienta a interação entre os indivíduos, permitindo que as relações sociais se tornem mais previsíveis. "When we say institutions structure human interactions what we mean is that they provide incentives and disincentives for people to behave in certain ways; and if they are effectiv they structure and provide incentives and also structure economic, political and social activity" (NORTH, 2003, p. 1). Assim, o funcionamento adequado das instituições facilita as relações sociais e reduz os custos de transação; ao contrário, seu mal funcionamento implica custos adicionais. As operações de comércio internacional, sem dúvida, fazem parte das transações que têm seu custo alterado em função da qualidade das instituições que as moldam.

North $(2003$, p. 3) ressalta que as instituições econômicas derivam diretamente das instituições políticas, e que todas as regras do jogo econômico são estabelecidas pela autoridade política - o Estado. Não obstante, a teoria de economia internacional, tradicionalmente, compreende as relações econômicas internacionais como decorrências das forças de mercado, expressas pelas relações entre oferta e demanda. O Estado é considerado variável exógena ao modelo, desempenhando um papel limitado sobre a determinação das relações de comércio internacional (apenas por meio da imposição de tarifas ou concessão de subsídios) (FAUCHER e NIOSI, 1990). Em oposição a essa visão, entendemos que o Estado constitui-se como agente central na orientação da atividade de comércio internacional de um país, por meio do estabelecimento de instituições que atuarão como incentivos positivos ou negativos para que as operações se realizem. Conforme se verá ao longo do desenvolvimento deste trabalho, o Estado brasileiro - na figura do governo - é o grande responsável pela conformação do quadro institucional sob o qual se desenvolvem as relações de comércio internacional do Brasil.

\footnotetext{
${ }^{5}$ Douglas North, juntamente com Robert William Fogel, recebeu o Prêmio Nobel em Economia em 1993, pelo seu trabalho na área da história econômica. North é reconhecido pela academia por ter renovado a pesquisa em história econômica, aplicando métodos quantitativos à análise das mudanças institucionais.
} 


\subsection{Instituições e comércio internacional}

Entendemos que a análise do impacto institucional sobre o comércio internacional de um país tem de ser feita a partir de dois enfoques: o das instituições domésticas e o das instituições internacionais. As instituições domésticas (considerando-se apenas as instituições formais) são aquelas provenientes do Estado, materializadas no arcabouço jurídico que rege as relações sociais, incluindo as relações econômicas. Do ponto de vista do comércio, são as normas que regulamentam as operações de importação e exportação em todos os seus aspectos: burocrático, financeiro, tributário, contratual etc.

Existem, contudo, normas que são impostas internamente em decorrência de compromissos assumidos por um país no plano internacional, os quais regem as relações entre os Estados no plano internacional, mas tem implicações internas para os países. Esse conjunto de princípios e regras sobre em matéria comercial, estabelecido pelos Estados no âmbito internacional, constitui o chamado regime internacional de comércio $^{6}$. No plano multilateral, a governança do regime cabe em especial à Organização Mundial do Comércio (OMC). Paralelamente a ela, existem diversos acordos regionais de comércio, os quais impõem um arcabouço normativo específico para as partes. Disso resulta a existência de subsistemas de governança e regulamentação do comércio internacional, como o que ocorre no âmbito do MERCOSUL.

A abertura de um país ao comércio internacional e sua exposição à concorrência global aumentam a volatilidade dos termos de troca dos produtos comercializados pelo país, incitando respostas dos governos nacionais diante dessa instabilidade. Consequentemente, em um contexto de abertura comercial, as políticas comerciais também apresentam variações maiores e mais frequentes do que ocorre em mercados fechados. Por isso, para Mansfield (2007), as instituições internacionais de comércio, mais do que promover redução dos níveis tarifários e o aumento dos fluxos comerciais mundiais, têm a função de conferir estabilidade às políticas comerciais nacionais e

\footnotetext{
${ }^{6}$ Na definição de Krasner (1993, p. 1), um regime consiste em "principles, rules, and decisionmaking procedures around which actor expectations converge in a given issue-area". Para Lipson (1983, p. 418), os regimes podem ser compreendidos como "institutions meditating economic and political intercourse". Entendemos que ambas as definições são válidas e complementares e estão relacionadas ao conceito de instituição que adotamos neste trabalho.
} 
reduzir a volatilidade dos fluxos de comércio, ao conferir maior previsibilidade às relações comerciais internacionais.

A importância do regime multilateral de comércio sobre o comportamento dos agente econômicos foi destacada por Lipson (1982), que analisou o impacto do regime em relação às políticas comerciais nacionais e em relação aos fluxos de comércio internacional. Lipson observou que a relação entre Estados e regime internacional é bidirecional e mutuamente condicionante: ao mesmo tempo em que os Estados interferem na constituição do regime, têm suas instituições e políticas domésticas por ele condicionadas - "an ongoing regime forms a significant context for the framing of national polities" (LIPSON, 1982, p. 446). Com relação aos fluxos comerciais, afirmou que a liberalização tarifária promovida no âmbito do regime estimulou o aumento do volume de comércio internacional, o qual vem sendo minimizada pelo crescimento das barreiras não tarifarias.

Sobre como as instituições internacionais contribuem para a previsibilidade do sistema, Anderson (2011) explica que elas são fundamentais para evitar que os atores caiam no dilema dos prisioneiros ${ }^{7}$. Do ponto de vista do comércio internacional, o dilema seria a situação em que um país, tendo em vista apenas seu próprio interesse e por não possuir informações suficientes sobre as políticas comerciais que serão adotadas por outros países, institui aumentos tarifários e outras medidas restritivas de comércio, impondo externalidades negativas sobre seus parceiros comerciais e provocando uma redução do benefício econômico global promovido pelo comércio internacional.

As instituições internacionais atuam no sentido de criar e tornar claras as regras do jogo, restringindo a adoção de políticas prejudiciais ao sistema e estabelecendo punições aos infratores. Dessa forma, elas reduzem as assimetrias de informação entre os atores e promovem o balizamento das expectativas. Além disso, fornecem incentivos para que todos cooperem com o sistema, pois, na ótica do dilema dos prisioneiros, o resultado individual de decisões tomadas em desacordo com os demais atores é pior quando estes estão concertados do que quando todos agem individualmente.

\footnotetext{
7 O dilema dos prisioneiros constitui uma hipótese relacionada à teoria dos jogos, que prevê que decisões racionais do ponto de vista individual (ou microeconômico) podem gerar resultados irracionais do ponto de vista coletivo (ou macroeconômico), o que seria provocado pela assimetria de informação e falta de confiança existentes entre os atores (vide SANDRONI, 2002, p. 174 , verbete "dilema do prisioneiro").
} 
$\mathrm{Na}$ prática, pode-se resumir os mecanismos de influência das instituições internacionais sobre a estabilidade das relações comerciais no seguinte: elas impõem meios para a execução dos compromissos de liberalização e de acesso a mercados, elas previnem a imposição de novas barreiras comerciais e elas aumentam a transparência e a convergência das políticas comerciais entre os países (MANSFIELD, 2007).

O que se verifica, atualmente, é que as regras do jogo estão ficando cada vez mais complexas. Tanto em nível multilateral quanto regional, os acordos comerciais, que surgiram com o objetivo de promover liberalização tarifária, vem ganhando escopo cada vez mais amplo. Há tempos a preocupação liberalizante voltou-se também para as barreiras não tarifarias - como as técnicas, sanitárias e fitossanitárias -, que já estão incorporadas nos acordos multilaterais de comércio. Mas acordos regionais mais recentes alcançam diversos outros aspectos das relações comerciais. A implicação disso é o aumento da complexidade e dos condicionantes para a normatização e para a elaboração de políticas domésticas sobre o comércio internacional.

\subsection{Qualidade das instituições e mudança institucional}

A qualidade das instituições domésticas é fundamental para que elas exerçam externalidades positivas sobre a atividade econômica e as relações comerciais de um país. Por isso promover mudanças e aperfeiçoamentos institucionais é condição indispensável para os países que buscam melhorar seu nível de desenvolvimento econômico.

A formação e a mudança institucional são fenômenos complexos, associados a múltiplas variáveis e em vários níveis de agência. Resolver esse problema vai além da vontade e da capacidade de escolha das sociedades. Além disso, muitas vezes, as dificuldades para promover boas mudanças institucionais já se iniciam na própria identificação das causas do mau desempenho econômico. Uma nação é, quase sempre, capaz de constatar seu atraso ou declínio em termos de crescimento e desenvolvimento econômico, mas identificar com precisão as causas dessa condição é muito mais difícil. Por isso, ocorre que as reformas institucionais adotadas podem não ser as mais adequadas frente às causas do problema.

A "importação" de instituições de países desenvolvidos não pode ser indicada 
como solução para o aperfeiçoamento institucional, pois fatores culturais e históricos impedem que as instituições apresentem o mesmo resultado em países diferentes (NORTH, 1995). A matriz institucional adotada por um Estado estabelece um leque de possibilidades de ação para seus indivíduos, mas a resposta dos indivíduos dependerá da sua percepção e interpretação da situação. Dessa forma, indivíduos com histórias e bagagens culturais diferentes poderão fazer escolhas diversas diante de uma mesma matriz institucional, alterando os impactos sociais e econômicos das instituições.

A mudança institucional, portanto, é considerada um processo gradual, incremental e path dependent (dependente da trajetória, em tradução livre), no sentido de que a condição atual e a trajetória futura das instituições decorrem de escolhas feitas no passado. Ou seja, a mudança institucional que se pretende adotar de um ponto para frente está necessariamente vinculada às escolhas institucionais feitas no passado, que constituem seu ponto de partida. Por esse motivo, nem sempre as mudanças institucionais refletem a melhor opção do ponto de vista do desempenho econômico, mas são opções possíveis dentro do contexto de path dependency.

Uma característica das instituições decorrente de sua condição de path dependent é seu caráter permanente. Esse caráter é positivo por um lado, pois confere maior estabilidade e previsibilidade ao sistema, permitindo às instituições influenciar o comportamento dos agentes. Por outro lado, a estabilidade torna mais difíceis os processos de mudança institucional.

Segundo North (1995), a mudança institucional em países menos desenvolvidos esbarra no problema do seu sistema de crenças, que está associado a uma característica histórica dessas sociedades: a incapacidade de criar instituições, políticas ou econômicas, impessoais. Outro fator limitante da mudança institucional é o grau de flexibilidade das organizações políticas nesses países. Uma vez que o sucesso do crescimento econômico depende da capacidade da matriz institucional de fornecer incentivos para o aumento da produtividade, as organizações políticas tem de ser suficientemente flexíveis para, diante de mudanças nas condições tecnológicas e competitividade da economia internacional, conseguir promover mudanças institucionais que promovam a competitividade da economia doméstica dentro do novo cenário. Quanto mais livres forem as estruturas políticas, mais fácil de se promover reformas institucionais.

Depreende-se disso que países menos desenvolvidos necessitam empreender mudanças institucionais para tornar o ambiente mais favorável ao desenvolvimento 
econômico, mas essas mudanças constituem um processo complexo e path dependent. O motivo é que as instituições são estáveis e refletem as tradições embutidas na sociedade. Apesar disso, as tradições não são imutáveis, pois existe um processo de constituição recíproca entre indivíduo e instituição, que faz com que as sociedades evoluam ao longo da história. Para que ocorra mudança institucional, portanto, é fundamental o papel de agente dos indivíduos.

Cabe destacar que a literatura ainda não chegou a uma definição unânime e universalmente aplicável do que são (ou devem ser) instituições de qualidade, capazes de estimular a economia e promover desenvolvimento. A grande maioria dos trabalhos a respeito do tema se concentra em conceitos abstratos, sem definir com precisão quais são e como se caracterizam as boas instituições. Outra constatação importante é de que a maioria dos estudos de caso sobre economia institucional diz respeito à trajetória dos países atualmente desenvolvidos. Por esse motivo, o problema institucional dos países em desenvolvimento ainda carece de mais estudos e teorização: faltam análises sobre as características e os impactos de mudanças institucionais.

Este trabalho não tem a pretensão de definir todo o rol de variáveis institucionais relevantes para o comércio internacional, nem de estabelecer as características institucionais ideais para a promoção do comércio e do desenvolvimento. Entendemos que a compreensão do objeto concreto deve preceder a generalização e a teorização. Por isso, o trabalho será dedicado à tentativa de compreender algumas das instituições relevantes para o comércio exterior do Brasil na atualidade, um primeiro passo para que trabalhos futuros possam avançar no tema.

Levando em consideração a característica de dependência histórica das instituições discutida nessa seção, dedicaremos os capítulos 2 e 3 deste trabalho a analisar a evolução histórica das instituições domésticas e internacionais que afetam o comércio internacional brasileiro na atualidade. 


\section{A EVOLUÇÃo INSTITUCIONAL EM NÍVEL NACIONAL: A POLÍTICA COMERCIAL BRASILEIRA NO SÉCULO XX}

O presente capítulo tem por objetivo apresentar a evolução interna das instituições relativas ao comércio exterior ao longo do século $X X$, indicando as principais características de política comercial e as mudanças burocráticas mais significativas ao longo do período de análise. Os governos Cardoso, Lula e Rousseff serão tratados com um pouco mais de detalhe pois a eles estão associadas grande parte da estrutura normativa e das características das burocracias que regem o comércio exterior brasileiro na atualidade.

\subsection{O viés protecionista da industrialização por substituição de importações na primeira metade do século $X X$}

No Brasil do século $\mathrm{XX}$, por muitas décadas, o comércio exterior vinculou-se à ideia de crescimento econômico segundo a ótica desenvolvimentista dos países periféricos. A partir de influências da CEPAL e do pensamento de importantes economistas desenvolvimentistas, a política protecionista de comércio exterior foi vista como instrumento de estímulo à construção de uma indústria nacional ${ }^{8}$. Por isso, o foco da política comercial recaía sobre o controle das importações mais do que sobre o fomento às exportações, no que ficou conhecido como processo de industrialização por substituição de importações (PSI).

A substituição de importações constituiu a segunda fase do processo de industrialização brasileira, avançando em relação à fase inicial, ocorrida no século XIX, quando apenas a indústria têxtil conseguiu se desenvolver ao amparo da economia exportadora de produtos primários (FURTADO, 2007, 2011). O PSI foi uma fase de industrialização mais complexa e, de acordo com Furtado (2007), foi engendrada pelo declínio do setor exportador brasileiro em meio à crise iniciada em 1929, a qual limitou consideravelmente a capacidade brasileira de importação. Nesse período, o papel do

\footnotetext{
8 Nesse sentido, valem ser destacados Raúl Prebisch, economista argentino que inaugurou o pensamento estruturalista no âmbito do CEPAL e formulou a teoria da deterioração dos termos de troca; Celso Furtado, economista brasileiro representante do estruturalismo, com um trabalho vasto a respeito de história econômica brasileira e de desenvolvimento econômico no Brasil e na América Latina; Maria da Conceição Tavares, Carlos Lessa e Antônio Barros de Castro, economistas heterodoxos e de orientação neoestruturalista brasileira.
} 
Estado foi visto como essencial ao fomento do desenvolvimento industrial, e o governo, de fato, adotou políticas cambiais, creditícias e tarifárias direcionadas a esse objetivo (GREMAUD; VASCONCELLOS; TONETO JR., 2007).

As tarifas, no entanto, não eram o principal instrumento de controle das importações. Segundo Bonelli et al (1997), historicamente, as barreiras não tarifárias foram a regra. Controles de câmbio e desvalorizações cambiais, em muitos períodos, foram amplamente utilizados e mostraram-se mais efetivos do que qualquer imposto de importação, embora alguns autores acreditem que a preocupação do governo fosse antes o problema do balanço de pagamentos do que propriamente a industrialização por substituição de importações (BONELLI ET AL. 1997). Segundo Fernandes (2010), o PSI foi mais uma consequência indireta dos choques externos da economia do que uma política deliberada.

Até a década de 1950, a atuação do governo na indução do PSI foi pouco significativa, e o principal ingerente sobre as operações de comércio exterior era a autoridade monetária, com suas políticas de controles cambiais e restrição às importações. Contudo, em 1953, a Instrução 70 da Superintendência de Moeda e Crédito (SUMOC) representou um avanço em termos de normatização das operações de comércio exterior. Por meio da instrução, o governo instituiu um sistema de taxas múltiplas de câmbio, que procuravam estimular a exportação de produtos nacionais e, ao mesmo tempo, permitir a importação de insumos considerados essenciais. Vianna e Villela (2005, p. 34) explicam o funcionamento desse sistema cambial:

As taxas múltiplas de câmbio, determinadas através do sistema de leilões, permitiram, simultaneamente: a realização de amplas desvalorizações cambiais, que vieram substituir o controle de importações como instrumento de equilíbrio da balança comercial; e a manutenção de uma política de importações seletiva, onerando mais certos produtos e favorecendo a aquisição de outros, de acordo com o critério da essencialidade, e por consequência, de proteção à indústria doméstica.

A partir de 1954, a Carteira de Comércio Exterior do Banco do Brasil (CACEX) tornou-se um elemento central do PSI. A CACEX foi criada pela Lei $n^{\circ}$. 2.145, de 29 de dezembro de 1953, durante o governo de Getúlio Vargas, para ser o principal órgão responsável pelo desenvolvimento e pela execução da política comercial brasileira. Com esse avanço, o governo deixava de ser apenas reativo em relação à situação 
cambial e do balanço de pagamentos e passava a formular políticas comerciais diretamente associadas aos objetivos de política industrial (FERNANDES, 2010).

Em termos operacionais, a CACEX era um órgão do Banco do Brasil (BB), formalmente subordinado ao Ministério da Fazenda, mas com atuação situada na área do Ministério da Indústria e Comércio (MIC), e cujo diretor era nomeado diretamente pelo Presidente da República. Veiga (2009) destaca a importância dessa multiplicidade de laços burocráticos: a vinculação ao BB dava à carteira mais autonomia em questões de financiamento, enquanto as relações com os demais órgãos aumentavam sua capacidade de ação e coordenação.

Portanto, a Cacex atuava como instituição pública simultaneamente reguladora e operadora, provendo recursos financeiros, gerenciando incentivos fiscais e creditícios, promovendo exportações e comercializando diretamente produtos brasileiros. Além disso, consolidou-se como arena de negociação e de formação de interesses com os setores privados (...) [A] Cacex detinha o poder de arbitragem entre interesses divergentes. (VEIGA, 2009, p. 7).

Em 1957, uma reforma na legislação aduaneira mudou o caráter do sistema tarifário brasileiro. A Lei $n^{\circ}$. 3.244, de 14 de agosto de 1957, alterou, via de regra, a sistemática da cobrança do imposto de importação, de alíquota específica para ad valorem. Além disso, a lei criou o Conselho de Política Aduaneira (CPA), órgão do Ministério da Fazenda responsável pelo estabelecimento das alíquotas do Imposto de Importação (II) e pela modificação do imposto (para mais ou para menos) em casos excepcionais - como para estimular a produção nacional ou em caso de desabastecimento interno. Dessa forma, o Poder Executivo passou a exercer o controle seletivo das importações. Segundo Fernandes (2010), essa reforma tornou o Imposto de Importação o instrumento mais racional de controle das importações; apesar disso, os controles administrativos permaneceram sendo os mais utilizados.

\subsection{O período militar e as políticas de estímulo à exportação}

A partir dos governos militares, em ressonância com a orientação desenvolvimentista herdada das décadas anteriores, teve início uma política mais ativa de incentivo às exportações, com a utilização de políticas fiscais e creditícias. O objetivo dessa estratégia era melhorar a competitividade externa das exportações brasileiras 
sem que o governo tivesse que negociar bilateralmente aberturas comerciais, o que interferiria no objetivo prevalecente de industrialização por substituição de importações (PINTO et al, 2008).

A CACEX teve suas competências ampliadas e passou por um processo de fortalecimento logo no início do governo militar, por meio de alterações na Lei 2.145/53 realizadas entre 1964 e 1966. Além disso, em abril de 1964, o Decreto 53.889 criou a Comissão de Comércio Exterior (CCE), com o objetivo de promover e orientar a expansão do intercâmbio comercial do país. A CCE foi estabelecida no âmbito do Ministério de Indústria e Comércio, a quem cabia sua presidência, mas sua composição reunia representantes de diversos ministérios e órgãos associados à elaboração e à execução da política de comércio exterior? ${ }^{9}$.

À CCE, couberam competências de caráter mais genérico e político, como a formulação de diretrizes para a política de comércio exterior (ressalvadas as competências específicas de outros órgãos) e a coordenação das providências relacionadas, além da possibilidade de opinar sobre medidas de política monetária e fiscal relacionadas à política de comércio exterior. Enquanto isso, a CACEX manteve as competências mais operacionais sobre o comércio exterior, como a emissão de licenças, o exercício da fiscalização, a realização de financiamentos e a elaboração de estatísticas de comércio exterior.

Diante da multiplicidade de órgãos com competências relacionadas à formulação e implementação de políticas de comércio exterior, em 1966, foi estabelecido o Conselho Nacional de Comércio Exterior (CONCEX, criado pela Lei $n^{\circ} .5 .025$, de 10 de junho de 1966). O Conselho funcionou como instância máxima deliberativa e teve por objetivo eliminar a dispersão decisória que havia em relação ao tema. Assim como a CCE, o CONCEX era presidido pelo Ministro do MIC e composto por um colegiado de autoridades, contudo, de mais alto níve $\left.\right|^{10}$. À CACEX, por seu turno, coube a função de secretaria geral do CONCEX.

\footnotetext{
${ }^{9}$ Além do Ministro do MIC, os seguintes membros compunham a CCE: o Secretário-Geral Adjunto para Assuntos Econômicos, do Ministério das Relações Exteriores; o Presidente do Banco Nacional de Desenvolvimento Econômico; o Presidente do Conselho de Política Aduaneira; o Superintendente da Superintendência Nacional do Abastecimento; o Diretor Executivo da Superintendência da Moeda e do Crédito; o Diretor da Carteira de Comércio Exterior do Banco do Brasil S.A e o Diretor da Carteira de Câmbio do Banco do Brasil S. A.

10 Compunham o CONCEX: o Ministro da Indústria e Comércio (presidente do CONCEX), o Ministro das Relações Exteriores, o Ministro da Fazenda, o Ministro da Agricultura, o Ministro dos Transportes, o Ministro de Minas e Energia, o Presidente do Banco Central do Brasil, o Presidente do Banco do Brasil S.A. e o Diretor da Carteira de Comércio Exterior (CACEX).
} 
Segundo Fernandes (2010), a designação da CACEX para secretariar o Conselho foi determinante para que a Câmara deixasse de ser um órgão meramente operacional e passasse a ter ingerência em todos os assuntos relativos a comércio exterior. Ademais, como a maior parte das políticas protecionistas era exercida por meio de controles administrativos, a CACEX acabou tendo um papel fundamental na execução da política desenvolvimentista do Estado.

Em linha com o objetivo de fomento das exportações do período militar, em 1964, o governo instituiu o regime de drawback, por meio do qual desonerou tributos de importação sobre insumos destinados à produção de mercadorias para exportação ${ }^{11}$. Pouco depois, em 1966, foi criado o Fundo de Financiamento às Exportações (FINEX), destinado à suprir lacunas de financiamento privado para operações pré-embarque de bens de capital e consumo duráveis. No mesmo ano, foi instituído um fundo de financiamento de capital de giro para empresas exportadoras de produtos manufaturados e foi concedida isenção de ICM para exportação desses produtos.

De acordo com Fonseca (2015), a criação do FINEX representou um importante avanço do Brasil no sentido de ampliar a exportação de manufaturados e diversificar os mercados de destino, contribuindo para a modernização da economia brasileira. Segundo o autor, a linha foi estabelecida para atender setores produtivos de manufaturados que encontravam-se em expansão no país, como o setor automotivo, a indústria de alimentos, os setores de calçados e vestuário, móveis, máquinas e equipamentos e metalurgia, entre outros, os quais, de maneira pioneira, passaram a atingir mercados de países em desenvolvimento na América-Latina e na África. Graças ao fundo, foram viabilizadas condições de financiamento mais equânimes em relação ao mercado internacional, e as exportações brasileiras de produtos manufaturados foram de tal forma favorecidas que chegaram a atingir cerca de $60 \%$ da pauta exportadora (FONSECA, 2015).

Entre 1969 e 1970, foram criados os créditos-prêmio de IPI (Imposto sobre Produtos Industrializados) e de ICM (Imposto sobre Circulação de Mercadorias), a fim de ressarcir o exportador dos tributos incidentes sobre as vendas ao exterior, por meio da compensações com tributos devidos em operações internas. Em 1971, foi autorizada a exclusão da base de cálculo do Imposto de Renda do lucro auferido nas exportações de diversos produtos manufaturados e semimanufaturados.

11 O regime de drawback foi estabelecido no Brasil pelo Decreto $n^{\circ} .53 .967$, de 16 de junho de 1964. 
Um ano depois, foi estabelecida a Comissão de Benefícios Fiscais e Programas Especiais de Exportação, denominada BEFIEX, que concedeu benefícios tributários para a importação de bens de capital e insumos de produção destinados à fabricação de mercadorias para o mercado interno, mas vinculados a obrigatoriedade de exportação de parte da produção (sendo o benefício calculado a partir do valor exportado ${ }^{12}$. Segundo Baumann (1990), os objetivos da BEFIEX eram estimular a geração de divisas para o país e, ao mesmo tempo, propiciar a atração de investimentos em razão dos menores custos de produção.

Em 1979, foi criado mecanismo de equalização da taxa de juros, a fim de equilibrar as taxas internas de financiamento das exportações com as praticadas no mercado internacional ${ }^{13}$. O diferencial entre a taxa de juros interna e a internacional era coberto por recursos do Fundo de Financiamento à Exportação (FINEX) e o benefício era disponibilizado tanto ao exportador brasileiro quanto ao importador estrangeiro, tanto para bens quanto para serviços.

Nota-se, assim, que entre meados da década de 1960 e o fim da década de 1970, o governo brasileiro instituiu diversos mecanismos de financiamento e desoneração tributária das exportações, ou de importações relacionadas a exportações, com o objetivo de melhorar a competitividade da indústria nacional e alavancar as vendas externas. O período também se caracterizou pela centralização da competência normativa e da gestão de políticas (pela CACEX) e pelo estabelecimento de um foro de articulação interministerial (o CONCEX).

Enquanto Secretaria Executiva do CONCEX, na prática, a CACEX constituiu o órgão efetivo de elaboração e condução da política de comércio exterior do Brasil. Por isso, tornou-se o principal locus de confronto de interesses, tanto das burocracias quanto do setor privado:

Os interesses privados buscaram obter espaços de influência no processo interno da Cacex, que se transformou numa arena de articulação e agregação de interesses e palco de um intricado jogo de interesses e alianças extra e intra-burocráticas devido ao aumento de

\footnotetext{
${ }^{12}$ A BEFIEX foi instituída pelo Decreto-lei $\mathrm{n}^{\circ}$. 1.219 , de 15 de maio de 1972 , e regulamentada pelo Decreto $n^{\circ}$. 71.278, de 31 de outubro de 1972. Baumann (1990) explica que a Comissão foi originalmente concebida como um órgão ligado à assessoria do ministro da Fazenda e, em 1974, foi transferida para o Ministério da Indústria e Comércio, junto à Secretaria Executiva do Conselho de Desenvolvimento Industrial (CDI).

${ }^{13}$ A equalização da taxa de juros foi estabelecida pela Resolução 509 do Conselho Monetário Nacional, de 24 de janeiro de 1979.
} 
seu papel da definição da política comercial. (FERNANDES, 2010, p. 59).

Com relação às importações, a industrialização baseada no PSI traduziu-se em uma política seletiva, aberta à entrada de bens sem similar nacional ou em situação de desabastecimento temporário, mas restritiva em relação às demais entradas. O controle das importações era baseado tanto em tarifas elevadas quanto em controles discricionários, como lista de produtos proibidos ou limite anual de importação de determinados produtos (KUME; PIANI; SOUZA, 2003).

O modelo de crescimento baseado na substituição de importações, no entanto, entraria em uma fase de esgotamento no final da década de 1970, após os anos do chamado "milagre brasileiro"14. O declínio desse paradigma econômico, que vigorava no Brasil desde a década de 1930, ocorreu em um contexto de forte endividamento externo, agravado pela conjuntura econômica internacional negativa frente aos choques do petróleo de 1973 e 1979. A política comercial, que vinha sendo subordinada aos objetivos da política industrial, teve seu foco redirecionado para o problema do balanço de pagamentos, pois os superávits comerciais eram imprescindíveis ao país para fazer frente aos encargos da dívida externa (HERMANN, 2005).

\subsection{Redemocratização, abertura e desmantelamento das políticas de estímulo à exportação}

A partir da segunda metade da década de 1980, o agravamento das restrições financeiras externas e a conjuntura de hiperinflação interna levaram à interrupção da maior parte das políticas de apoio à exportação no Brasil. Com os esforços concentrados no combate à inflação, o Estado não foi capaz de coordenar e implementar mecanismos de apoio ao setor exportador. Além disso, em razão dos compromissos assumidos no GATT, o Brasil já vinha sofrendo pressões externas em relação a suas políticas de apoio às exportações, o que contribuiu para a decisão de seu desmantelamento (BONELLI et al,1997; PINTO et al, 2008).

\footnotetext{
14 Milagre brasileiro é como ficou conhecido o período entre 1968 e 1973, quando a economia brasileira cresceu a uma taxa média de $11 \%$ ao ano, com destaque para o setor de bens de consumo durável, seguido pelo setor de bens de capital (HERMANN, 2005).
} 
Assim, o primeiro governo pós redemocratização, do Presidente José Sarney, foi marcado por um retrocesso dos mecanismos de incentivo e financiamento das exportações adotados ao longo dos governos militares. Tanto o FINEX quanto a equalização de juros foram desativados em 1988, restando apenas os incentivos do drawback e da isenção de IR sobre receitas de exportação e alguns compromissos remanescentes da BEFIEX (extinto em 1990). Com relação à política de importações, houve uma tentativa de modernização da legislação aduaneira em 1988, incluíndo reduções tarifarias, eliminação de tributos e supressão de regimes especiais. Contudo, segundo Kume, Piani e Souza (2003), as mudanças ficaram aquém do que havia sido proposto pelo CPA, em razão de pressões de grupos que seriam negativamente afetados pelas reformas.

Fernandes (2010) afirma que a década de 1980 representou o afastamento da política comercial dos objetivos industriais desenvolvimentistas, que foram substituídos pela preocupação maior com os superávits comerciais. Segundo o autor, houve generalização da adoção de barreiras não tarifárias às importações e flexibilização nos critérios das políticas de incentivo à exportação, a fim de promover maior ampliação do saldo comercial. Mesmo a reforma aduaneira de 1988 não reduziu o nível das barreiras não tarifárias (KUME; PIANI; SOUZA, 1988), que só seriam revistas no governo seguinte.

Com a presidência de Fernando Collor de Mello, teve início, em 1990, um processo de abertura econômica e comercial e de abandono claro da estratégia de industrialização por substituição de importações. Do ponto de vista comercial, a intenção era submeter a indústria nacional à concorrência estrangeira, a fim de torná-la mais eficiente e competitiva. A estratégia de política comercial do governo foi consubstanciada na PICE - Política Industrial e de Comércio Exterior, que previa uma nova estrutura tarifária para o comércio exterior e a adoção de políticas industriais mais horizontais e menos setoriais, como ocorria anteriormente.

Em relação às barreiras tarifárias, a nova política de importações adotou importantes medidas liberalizantes, como reduzir a zero a alíquota do imposto de importação de bens não produzidos no país (o que compreendeu mais de 1.600 produtos) e reduzir pela metade a alíquota de bens produzidos internamente em condições monopolísticas (aproximadamente 570 mercadorias). Além disso, foi elaborado um cronograma de desgravações, programado para ocorrer entre 1991 e 1994, que reduziria as alíquotas de importação de aproximadamente 13.500 produtos, 
levando a uma alíquota média de 14,2\% (contra uma alíquota média de 32,2\% em 1990). Em complementação, foi realizada uma grande redução da barreiras não tarifárias, de tudo o que não possuísse amparo legal. Com essa política de importações, - governo procurava combater o que considerava um tema de forte tradição intervencionista do Estado (MELLO, 1991, p. 23).

Na mesma linha de redução do intervencionismo, diversos órgãos centrais da administração pública associados ao comércio exterior foram desmantelados. Dois deles foram a CACEX e o CPA, extintos em 1990, cujas atribuições foram transferidas para o Departamento de Comércio Exterior (DECEX) do Ministério da Economia, Fazenda e Planejamento (MEFP). A CACEX constituía o símbolo e a síntese institucional da PSI, portanto, incompatível com os novos objetivos da política comercial. Em 1992, foi criado o Ministério da Indústria, do Comércio e do Turismo (MICT), e as competências dos extintos CACEX e CPA ficaram concentradas nesse novo ministério.

A crítica que Fernandes $(2010$, p. 70$)$ faz em relação a essa mudança burocrática é de que a migração das atribuições da CACEX para o DECEX rebaixaram a política de comércio exterior brasileira do patamar de um órgão de primeira grandeza, e diretamente ligado à Presidência da República, para um órgão de terceiro escalão de um ministério cuja preocupação central era o plano de estabilização. Além disso, Fernandes afirma que a mudança provocou a redução da interlocução entre o setor privado e as instâncias formuladoras da política comercial:

A reforma administrativa realizada por Collor, que extinguiu as principais instituições implementadoras da política comercial desenvolvimentista - a Cacex e o CPA, resultou na eliminação dos canais de participação do setor privado na definição da política comercial e na centralização das decisões em política comercial nas mãos de alguns poucos economistas que compunham a equipe econômica no topo da hierarquia do MEFP. (FERNANDES, 2010, p. 70).

O autor também destaca que a extinção da CACEX teve um papel importante na política de liberalização das importações, já que a Carteira era responsável pela análise e concessão dos regimes especiais de importação, o que implicava grande discricionariedade na concessão das licenças de importação:

Como conseguiam, por meio das decisões da Cacex importar mercadorias sem o pagamento de impostos de importação, muitas 
empresas pleiteavam seu enquadramento em algum regime especial. Isso levou a proliferação desses mecanismos e à expansão de relevante parcela das importações em regimes de benefícios fiscais, anulando o intento inicial das licenças, que era economizar moeda estrangeira, tendo como consequência o encastelamento destes interesses associados com a manutenção da capacidade decisória da Cacex. (FERNANDES, 2010, p. 69).

Com relação às exportações, Pinto et al (2008) afirmam que, no início da década de 1990, seu financiamento dependia preponderantemente de mecanismos privados, como os Adiantamentos de Contrato de Câmbio - ACC. Não obstante, o governo deu atenção especial aos bens de capital e criou, ainda em 1990, o programa de crédito do BNDES para financiar operações pré-embarque de exportações dessa natureza, o FINAMEX. Em 1991, o programa foi estendido para exportações de bens e serviços e o governo regulamentou o Programa de Financiamento às Exportações - PROEX. Este, diferentemente do FINAMEX, era administrado pelo Banco do Brasil e obtinha recursos do Tesouro Nacional. Além disso, prestava-se tanto a financiamento quanto a equalização de taxas de juros, para exportações de bens e serviços, exceto commodities. Da mesma forma que o antigo FINEX, O PROEX foi disponibilizado aos exportadores brasileiros e aos importadores de mercadorias brasileiras no exterior. Fonseca (2015) destaca que o PROEX foi inspirado no modelo de financiamento público adotado pelos Estados Unidos à época, por meio do Exim Bank, tanto que, posteriormente, o FINAMEX teria seu nome alterado para BNDES-Exim (como permanece até hoje).

Em 1992, o governo lançou a Política Ativa de Comércio Exterior - PACE -, a qual adotou diversas medidas relativas ao PROEX (como quanto à origem dos recursos, à lista de produtos e aos prazos de financiamento). Além disso, foi estabelecida a isenção de IPI para vendas internas a determinadas empresas com contratos de prestação de serviços no exterior e foi criado o drawback verde-amarelo, para suspensão de IPI nas aquisições internas de insumos destinados à fabricação de mercadorias para exportação. A nova política preocupou-se, também, com o fornecimento de auxílio e treinamento aos exportadores brasileiros, e o governo passou a distribuir informes técnicos sobre exportação e criou os serviços disque-decex e disque-aduana, para informar o público sobre procedimentos operacionais.

Outro importante avanço do período foi a criação do Sistema Integrado de Comércio Exterior - SISCOMEX, em setembro de 1992, o qual consiste em um sistema 
único e informatizado que integra as atividades de registro, acompanhamento e controle das operações de importação e exportação do Brasil ${ }^{15}$.

A década de 1990, portanto, registrou o restabelecimento das linhas públicas de crédito a exportação. Apesar disso, análises do período Collor consideram que a política de exportações não foi prioritária para o governo, o qual ocupou-se, antes, da política de desoneração das importações (VEIGA; RIOS, 2009; PINTO et al., 2008). A ideia era de que essa estratégia também beneficiaria as exportações, ao reduzir os custos dos bens de capital e insumos importados. Em linhas gerais, foi um período de política liberalizante e de desmantelamento das estruturas burocráticas anteriormente ligadas à política protecionista do PSI. Faltou ao governo, contudo, a estruturação e o empodeiramento de novas burocracias, capazes de reorientar os rumos da política de comércio exterior brasileira.

\subsection{Estabilização econômica, tentativa de centralização da política comercial e retomada do apoio à exportação}

Os primeiros anos da década de 1990 foram relativamente favoráveis às exportações brasileiras, tendo em vista os níveis da taxa de câmbio e o baixo dinamismo do mercado interno. No entanto, o início do governo Fernando Henrique Cardoso ( $F H C)$ e a reforma monetária promovida pelo Plano Real provocaram uma inversão dessa situação. A alta das importações decorrente da abertura econômica (iniciada no governo Fernando Collor) e a queda das exportações em virtude do câmbio valorizado provocaram déficits comerciais consecutivos a partir de 1995.

A deterioração dos resultados da balança comercial que se verificou a partir de então levou o governo a intensificar os esforços para implantação de uma política de exportações. Nesse sentido, em 1995, o governo criou a Câmara de Comércio Exterior (CAMEX), órgão colegiado cujo objetivo central era promover a coordenação das instâncias formuladoras e aplicadoras da política de comércio exterior, superando o problema de dispersão das instâncias decisórias do comércio exterior.

A CAMEX, instituída pelo Decreto 1.386, de 6 de fevereiro de 1995, era originalmente composta pelos ministros Chefe da Casa Civil, das Relações Exteriores,

\footnotetext{
${ }^{15}$ O SISCOMEX foi instituído pelo Decreto 660 , de 25 de setembro de 1992. Para mais informações, vide <http://www.mdic.gov.br/siscomex/siscomex.html>.
} 
da Fazenda, do Planejamento e Orçamento, da Indústria, Comércio e Turismo e da Agricultura, Abastecimento e Reforma Agrária ${ }^{16}$. A Câmara vinculava-se ao Conselho de Governo da Presidência da República e era presidida pelo Ministro Chefe da Casa Civil. Além da própria Câmara de Ministros, a CAMEX é composta por uma secretaria executiva, cujo secretário é nomeado pelo Presidente da República. Suas atribuições incluiam as seguintes atividades ${ }^{17}$ :

I - definir as diretrizes da política de comércio exterior;

II - manifestar-se previamente sobre as normas e legislação sobre o comércio exterior e temas correlatos;

III - dispor sobre as diretrizes para as alterações das alíquotas dos impostos e de exportação;

IV - estabelecer as diretrizes para as investigações relativas a práticas desleais de comércio exterior;

$V$ - fixar as diretrizes para a política de financiamento e de seguro de crédito às exportações;

$\mathrm{VI}$ - estabelecer as diretrizes para a política de desregulamentação do comércio exterior;

VII - avaliar o impacto das medidas cambiais, monetárias e fiscais sobre o comércio exterior;

VIII - formular a política sobre a concessão de áreas de livre comércio, zonas francas e zonas de processamento de exportações;

IX - fixar as diretrizes para a promoção de bens e serviços brasileiros no exterior;

$\mathrm{X}$ - indicar os parâmetros para as negociações bilaterais e multilaterais relativas ao comércio exterior.

${ }^{16} \mathrm{O}$ Decreto $\mathrm{n}^{\circ}$. 1.386/95 foi posteriormente revogado e substituído, sucessivamente, pelos seguintes decretos: Decreto $n^{\circ}$. 3.756, de 21 de fevereiro de 2001; Decreto $n^{\circ}$. 3.981, de 24 de outubro de 2001; e Decreto $n^{\circ} .4 .732$, de 10 de junho de 2003 (este último alterado pelo Decreto $n^{\circ}$. 4.993, de 2004, pelo Decreto $n^{\circ}$. 5.398, de 2005, pelo Decreto $n^{\circ} .6 .229$, de 2007, e pelo Decreto ${ }^{\circ}$. 6.547, de 2008). Até o afastamento da Presidente Dilma da Presidência, a CAMEX foi composta pelo Ministro do Desenvolvimento, Indústria e Comércio exterior, a quem cabe sua presidência, e pelos Ministros Chefe da Casa Civil, das Relações Exteriores, da Fazenda, da Agricultura, Pecuária e Abastecimento, do Planejamento, Orçamento e Gestão e do Desenvolvimento Agrário. Atualmente, com as alterações promovidas pelo governo provisório, a presidência da Câmara passou a ser exercida pelo Presidente da República. Para mais informações, vide www.camex.gov.br.

17 Conforme o artigo $1^{\circ}$ do Decreto 1.386/95. 
Nota-se que a CAMEX tem como característica principal seu caráter consultivo, constituindo um foro de debate e coordenação de políticas, não lhe cabendo atribuições operacionais. Sua estrutura de órgão colegiado tinha por objetivo permitir o diálogo e a solução de divergências interministeriais, envolvendo todas as burocracias relacionadas à formulação e execução de políticas de comércio exterior. Além disso, conforme destacaram Veiga e Rios (2009), a CAMEX tornou-se um importante mecanismo de diálogo entre o governo e o setor privado, assim como ocorria anteriormente com a CACEX.

Por estar ligada diretamente à Presidência, a CAMEX ficava fisicamente localizada no Palácio do Planalto, o que, segundo Fernandes (2010, p. 79), Ihe conferia "grande poder convocatório" e angariava a presença dos Ministros em suas reuniões. Apesar disso, Fernandes (2010) considera que o governo, com a criação da Câmara, não teve sucesso em dirimir os conflitos burocráticos relacionados à divisão de competências sobre a política de comércio exterior. Segundo ele, o comércio exterior não esteve entre as prioridades do primeiro mandato de $\mathrm{FHC}$, que foi muito menos ousado na criação da CAMEX do que havia sido o Presidente Collor na extinção da CACEX:

A Camex foi a solução encontrada no $1^{\circ}$ mandato de Cardoso para resolver o problema da dispersão e pulverização institucional no comércio exterior criados após a extinção da Cacex, sem agredir os interesses dos principais ministérios envolvidos com temas conexos à política comercial e que haviam ganhado maior espaço no comércio exterior pós-abertura. Foi uma solução institucional limitada pela situação de conflito burocrático que emergiu dentro da estrutura institucional da política comercial após a reforma em negativo feita no governo Collor. (...) Podemos concluir até o momento que a solução institucional encontrada com a criação da Camex visava reduzir o problema da falta de coordenação sem afetar as competências e interesses dos outros ministérios (grifo nosso). (FERNANDES, 2010, p. 81).

O segundo mandato do governo FHC viria a ter um viés um pouco diferente em relação à política comercial, efetivamente mais voltado para a promoção comercial e fomento das exportações. A necessidade se impunha diante das dificuldades enfrentadas pelo balanço de pagamentos, provocadas pelo grande aumento das importações que resultou da apreciação cambial promovida pelo Plano Real. Nesse contexto, o governo anunciou, ainda no final do primeiro mandato, a criação de um novo 
ministério em substituição ao MICT, o Ministério do Desenvolvimento, Indústria e Comércio Exterior (MDIC).

O MDIC foi criado para ser um ministério fortalecido, reunindo órgãos proeminentes como o MICT, O BNDES e a SUFRAMA, e seu objetivo consistia na formulação da política industrial e de exportação. Nesse sentido de fortalecimento, foram transferidos ao MDIC a secretaria executiva e a presidência da CAMEX (mudança que Veiga e Rios (2009) consideram uma "ambiguidade institucional", com relativa prevalência de um ministério sobre os demais do órgão colegiado).

Fernandes (2010) registra que o MDIC, com um corpo burocrático de características mais desenvolvimentista, foi planejado para ser um ministério que fizesse um contraponto às políticas mais ortodoxas do Ministério da Fazenda e que, apesar da tentativa de fortalecimento do MDIC, a política econômica do Ministério da Fazenda acabou sempre prevalecendo. Segundo o autor, este seria o ministério mais forte em relação a todos os temas relacionados a comércio exterior.

Cabe destacar que, a partir de fevereiro de 2001, as decisões da CAMEX passaram a ser emitidas na forma de Resolução, com caráter vinculante em relação aos 6 ministérios que compõem o colegiado, superando o caráter consultivo que tinham as deliberações do órgão até então ${ }^{18}$. Com isso, a CAMEX passou a ter competências para fixar as alíquotas dos impostos de importação e exportação e para decidir sobre medidas de defesa comercial. Antes disso, a fixação dos impostos de importação e exportação cabiam ao Ministério da Fazenda, enquanto as medidas de defesa comercial eram definidas em conjunto entre este e o Ministério do Desenvolvimento. Por essa nova sistemática, qualquer ministério, na prática, detém um poder de veto em relação as decisões da CAMEX, já que as resoluções têm de ser tomadas por consenso.

$\mathrm{Na}$ contramão das reformas que fortaleceram a CAMEX, no entanto, em outubro de 2001, foi realizada uma reforma que alterou as atribuições do órgão. Por meio do Decreto 3.981/01, a CAMEX deixava de ter o objetivo de formulação da política de comércio exterior, para limitar-se apenas a adoção, implementação e coordenação da política. Segundo Fernandes (2010), a redução do escopo deve ser atribuída aos conflitos entre as burocracias, sobretudo entre Fazenda e Desenvolvimento, e que a reforma restringiu o escopo e a importância da CAMEX como órgão central da política de comércio exterior:

18 Conforme estabelecido pelo Decreto 3.756, de 21 de fevereiro de 2001. 
A Câmara deixou de ser um órgão de formulação, tornando-se apenas um veículo de implementação e coordenação da política comercial, numa clara demonstração da disfuncionalidade que sua transferência para o MDIC trouxe para sua capacidade de se impor como locus de coordenação supraministerial. (FERNANDES, 2010, p. 109).

Os conflitos burocráticos entre MDIC e Fazenda, contudo, não impediram que algumas medidas de fomento às exportações fossem tomadas. Nesse sentido, buscouse aprimorar os mecanismos de financiamento e de desoneração tributária das exportações. Os recursos e a abrangência dos programas de financiamento foram ampliados e instrumentos públicos e privados de garantia ao crédito foram estabelecidos. Além disso, foram promovidas alterações na legislação tributária, a fim de permitir a tomada de crédito de tributos indiretos (PIS, COFINS, ICMS) incidentes sobre mercadorias destinadas à exportações e seus insumos, tornando os produtos mais competitivos no exterior.

O Quadro 1 abaixo apresenta o conjunto de medidas tomadas pelo governo entre os anos de 1995 e 2001, em diversas frentes estruturantes, com vistas a contribuir para o comércio exterior brasileiro. Nota-se que, além das desonerações tributárias e dos meios de financiamento, houve preocupação com a elaboração de ferramentas que facilitassem a operacionalização das operações e com a capacitação dos profissionais operadores do comércio exterior. Houve também uma medida de infraestrutura - a licitação de portos secos - e a criação de diversos programas voltados à exportação do produto brasileiro. Desses programas, um de grande destaque à época foi o Programa Especial de Exportação (PEE), lançado pela CAMEX em 1998 e que tinha por objetivo duplicar as exportações brasileiras até 2002. A falta de recursos e o estabelecimento de uma meta tão ambiciosa, contudo, levaram ao insucesso do programa.

Quadro 1 - Programas e ações de fomento à exportação durante o governo Cardoso

\begin{tabular}{|c|c|c|c|}
\hline & Programas e ações & Ano & Descrição \\
\hline 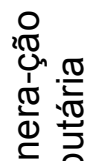 & $\begin{array}{l}\text { Redução da tributação } \\
\text { indireta sobre as } \\
\text { exportações }\end{array}$ & 1995 & $\begin{array}{l}\text { Ressarcimento de PIS e COFINS incidentes sobre } \\
\text { insumos dos produtos exportados. }\end{array}$ \\
\hline$\stackrel{\infty}{\infty}$ & $\begin{array}{l}\text { Aprovação da nova lei do } \\
\text { ICMS }\end{array}$ & 1996 & $\begin{array}{l}\text { Desonerou desse tributo cerca de um terço da pauta } \\
\text { de exportação brasileira. }\end{array}$ \\
\hline
\end{tabular}




\begin{tabular}{|c|c|c|c|}
\hline & $\begin{array}{l}\text { Ampliação do crédito } \\
\text { presumido de IPI }\end{array}$ & 1996 & $\begin{array}{l}\text { Ampliação das hipóteses de concessão do crédito } \\
\text { presumido de IPI, como forma de recuperação do PIS } \\
\text { e da COFINS incidentes sobre a compra de matérias- } \\
\text { primas, insumos e embalagens, reduzindo o custo } \\
\text { tributário das exportações. }\end{array}$ \\
\hline 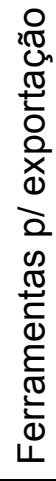 & $\begin{array}{l}\text { Modernização do } \\
\text { SISCOMEX-Exportação }\end{array}$ & 1999 & $\begin{array}{l}\text { Alterações com vistas à atualização de legislação, } \\
\text { atualização tecnológica e eliminação de controles } \\
\text { desnecessários para utilização do sistema. As } \\
\text { alterações tornariam o sistema mais ágil e amigável ao } \\
\text { público, reduziriam os custos de utilização e tornariam } \\
\text { mais célere o acompanhamento das operações de } \\
\text { comércio exterior. }\end{array}$ \\
\hline \multirow{6}{*}{ 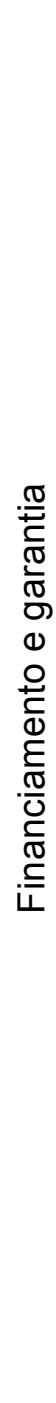 } & $\begin{array}{l}\text { Ampliação do programa } \\
\text { BNDES-Exim }\end{array}$ & 1997 & $\begin{array}{l}\text { - Aumento dos setores passíveis de financiamento } \\
\text { (bens de capital, manufaturados em geral, serviços } \\
\text { ligados à exportação) } \\
\text { - Melhora nos prazos e nos custos } \\
\text { - Criação de novas modalidades (1. modalidade Pré- } \\
\text { Embarque Especial; } 2 \text {. modalidade em que o risco do } \\
\text { exportador é assumido pelo BNDES; 3. modalidade de } \\
\text { financiamento diretamente do importador) } \\
\text { - Limite de crédito para instituições financeiras do } \\
\text { exterior, para atuarem como garantidoras do risco de } \\
\text { crédito } \\
\text { - Operações de financiamento em parceria com a } \\
\text { SBCE } \\
\text { - Criação de estruturas específicas para o } \\
\text { financiamento de exportação de aeronaves }\end{array}$ \\
\hline & $\begin{array}{l}\text { Ampliação do programa de } \\
\text { Financiamento às } \\
\text { Exportações - PROEX }\end{array}$ & 1998 & $\begin{array}{l}\text { - Passou a contemplar } 94 \% \text { dos produtos existentes na } \\
\text { Nomenclatura Comum do MERCOSUL }\end{array}$ \\
\hline & $\begin{array}{l}\text { Ampliação dos } \\
\text { financiamentos à } \\
\text { exportação do BNDES }\end{array}$ & 1996 & $\begin{array}{l}\text { Ampliação das operações alcançadas pelos } \\
\text { financiamentos. }\end{array}$ \\
\hline & $\begin{array}{l}\text { Criação da Seguradora } \\
\text { Brasileira de Crédito à } \\
\text { Exportação - SBCE }\end{array}$ & 1997 & $\begin{array}{l}\text { Medida do Programa de Financiamento às } \\
\text { Exportações }\end{array}$ \\
\hline & $\begin{array}{l}\text { Criação do Fundo de } \\
\text { Garantia à Exportação - } \\
\text { FGE }\end{array}$ & 1999 & $\begin{array}{l}\text { Medida do Programa de Financiamento às } \\
\text { Exportações }\end{array}$ \\
\hline & $\begin{array}{l}\text { Definição das bases do } \\
\text { Seguro de Crédito à } \\
\text { Exportação }\end{array}$ & 1996 & $\begin{array}{l}\text { Com o objetivo de retomar o mecanismo, que deixara } \\
\text { de operar na década de } 1980 .\end{array}$ \\
\hline
\end{tabular}




\begin{tabular}{|c|c|c|c|}
\hline & $\begin{array}{l}\text { Mudanças na legislação } \\
\text { das operações de ACC } \\
\text { (Adiantamento de } \\
\text { Contratos de Câmbio) }\end{array}$ & $\begin{array}{l}1995 \\
1997 \\
2000\end{array}$ & $\begin{array}{l}\text { - Uniformização dos prazos para todos os tipos de } \\
\text { produtos (1995) } \\
\text { - Ampliação do ACC para produtores de insumos } \\
\text { utilizados em mercadorias de exportação (1997) } \\
\text { - Ampliação do ACC para exportações de mercadorias } \\
\text { em consignação (2000) }\end{array}$ \\
\hline \multirow{4}{*}{ 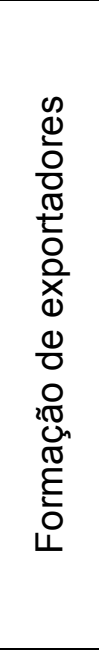 } & $\begin{array}{l}\text { Projeto Capacitação } \\
\text { Empresarial para o } \\
\text { Comércio Exterior }\end{array}$ & 1995 & $\begin{array}{l}\text { Destinado ao aperfeiçoamento do setor privado para } \\
\text { atuação no comércio exterior. }\end{array}$ \\
\hline & $\begin{array}{l}\text { Promoção de Encontros } \\
\text { de Comércio Exterior - } \\
\text { ENCOMEX }\end{array}$ & 1997 & $\begin{array}{l}\text { Encontros promovidos com a finalidade de estimular a } \\
\text { participação do empresariado nacional no comércio } \\
\text { internacional. }\end{array}$ \\
\hline & $\begin{array}{l}\text { Projeto Formação de } \\
\text { Agentes de Comércio } \\
\text { Exterior }\end{array}$ & 2000 & $\begin{array}{l}\text { Projeto para formação e capacitação de agentes de } \\
\text { comércio exterior em todos os estados da federação, a } \\
\text { fim de disseminar a cultura e o conhecimento técnico } \\
\text { sobre exportação pelo país. }\end{array}$ \\
\hline & $\begin{array}{l}\text { Programa Cultura } \\
\text { Exportadora }\end{array}$ & 2000 & $\begin{array}{l}\text { Buscou promover a conscientização da classe } \\
\text { empresarial para a importância do comércio exterior, } \\
\text { despertando o interesse pela exportação nas } \\
\text { empresas. }\end{array}$ \\
\hline 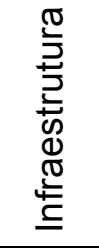 & Licitação de portos secos & 1996 & $\begin{array}{l}\text { Licitações destinadas a implantação de portos secos } \\
\text { no Brasil, o que descongestiona os portos e barateia os } \\
\text { trâmites aduaneiros para o exportador. }\end{array}$ \\
\hline \multirow{2}{*}{ 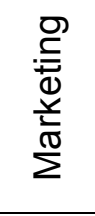 } & Marketing Brasil & 1995 & Projeto destinado à divulgação de produtos brasileiros. \\
\hline & Programa Design Brasil & 2000 & $\begin{array}{l}\text { Buscou ampliar a competitividade do produto nacional } \\
\text { no exterior por meio de inovações no design pelas } \\
\text { indústrias brasileiras. }\end{array}$ \\
\hline \multirow{2}{*}{ 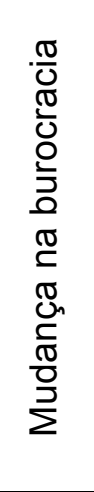 } & $\begin{array}{l}\text { Criação da Câmara de } \\
\text { Comércio Exterior - } \\
\text { CAMEX }\end{array}$ & 1995 & $\begin{array}{l}\text { Órgão colegiado, constituído por } 7 \text { ministérios, } \\
\text { responsável pela formulação e aplicação das políticas } \\
\text { de comércio exterior. }\end{array}$ \\
\hline & $\begin{array}{l}\text { Criação da Agência de } \\
\text { Promoção de Exportações }\end{array}$ & 1998 & $\begin{array}{l}\text { Agência criada no âmbito do SEBRAE (distinta da } \\
\text { APEX-Brasil atual, que integra o sistema MDIC). O } \\
\text { objetivo da agência era auxiliar na implementação da } \\
\text { política de promoção comercial e de exportações, } \\
\text { conforme determinações da CAMEX. A APEX também } \\
\text { atuava apoiando e financiando projetos (em até } 50 \% \\
\text { do seu custo total). }\end{array}$ \\
\hline$\frac{\pi}{\frac{\pi}{2}} \stackrel{\frac{\pi}{\varepsilon}}{\frac{\pi}{2}}$ & $\begin{array}{l}\text { Programa Novos Polos de } \\
\text { Exportação }\end{array}$ & 1995 & $\begin{array}{l}\text { Programa destinado a promover a exportação de } \\
\text { produtos selecionados a partir de polos regionais de } \\
\text { produção. }\end{array}$ \\
\hline
\end{tabular}




\begin{tabular}{|c|c|c|}
\hline $\begin{array}{l}\text { Programa Especial de } \\
\text { Exportações - PEE }\end{array}$ & 1998 & $\begin{array}{l}\text { Programa coordenado pela CAMEX. Objetivo: } \\
\text { identificar atividades de fomento necessárias e setores } \\
\text { produtivos com potencial exportador. Em 2001, havia } \\
61 \text { setores integrantes do PEE, cobrindo } \\
\text { aproximadamente } 88 \% \text { das exportações brasileiras. }\end{array}$ \\
\hline $\begin{array}{l}\text { Programa de Geração de } \\
\text { Negócios Internacionais - } \\
\text { PGNI }\end{array}$ & 1998 & $\begin{array}{l}\text { Objetivos: proporcionar acesso a crédito aos } \\
\text { exportadores, disponibilizar conhecimento técnico } \\
\text { dirigido à produção, fornecer acesso a informações } \\
\text { mercadológicas e procedimentos de comércio exterior, } \\
\text { promover a inserção competitiva da pequena e da } \\
\text { média empresa e sua permanência no mercado } \\
\text { internacional, melhorar a qualificação dos funcionários } \\
\text { do Banco do Brasil na área de comércio internacional, } \\
\text { assessorar clientes do banco na busca de parceiros no } \\
\text { exterior. }\end{array}$ \\
\hline Programa Brasil Trade Net & 1998 & $\begin{array}{l}\text { Compõe as ações de promoção comercial do Ministério } \\
\text { das Relações Exteriores. O sistema, baseado na } \\
\text { internet, coleta, identifica, processa e dissemina } \\
\text { informações de comércio exterior. Em 2001, o governo } \\
\text { divulgou que o Brasil Trade Net era o maior site do } \\
\text { gênero na América Latina. }\end{array}$ \\
\hline $\begin{array}{l}\text { Programa de Promoção de } \\
\text { Exportações e Acesso a } \\
\text { Mercados }\end{array}$ & 1999 & $\begin{array}{l}\text { Programa no âmbito do Ministério das Relações } \\
\text { Exteriores. Incluiu medidas como o aprimoramento do } \\
\text { sistema de informações e inteligência comercial do } \\
\text { Itamaraty - Brasil Trade Net -, o apoio à participação } \\
\text { brasileira em feiras internacionais, a promoção de } \\
\text { encontros do Comitê Empresarial Permanente. }\end{array}$ \\
\hline $\begin{array}{l}\text { Programa de Apoio à } \\
\text { Exportação - PAE }\end{array}$ & 1999 & $\begin{array}{l}\text { Desenvolvido pelo Banco do Brasil em parceria com a } \\
\text { APEX, com o objetivo de apoiar ações do governo para } \\
\text { o incremento das exportações, tais como: ampliação } \\
\text { da base de empresas exportadoras clientes do Banco } \\
\text { do Brasil, capacitação das empresas para atuar no } \\
\text { comércio exterior (treinamentos e prestação de } \\
\text { consultoria), apoio à formação de consórcios e } \\
\text { cooperativas de exportação. }\end{array}$ \\
\hline $\begin{array}{l}\text { Programa Brasil Classe } \\
\text { Mundial }\end{array}$ & 2000 & $\begin{array}{l}\text { Programa que teve por objetivo elevar a } \\
\text { competitividade da indústria nacional, e compreendeu } \\
\text { metas de geração de emprego e renda, } \\
\text { desconcentração produtiva regional, aumento das } \\
\text { exportações, substituição competitiva das importações, } \\
\text { inserção nas cadeias produtivas internacionais, } \\
\text { capacitação tecnológica das empresas e fortalecimento } \\
\text { das empresas de capital nacional. }\end{array}$ \\
\hline
\end{tabular}




\begin{tabular}{|l|l|l|}
$\begin{array}{l}\text { Programa de } \\
\text { Desenvolvimento do Setor } \\
\text { Exportador }\end{array}$ & 2000 & $\begin{array}{l}\text { - Desenvolvimento do sistema ALICE de estatísticas de } \\
\text { comércio exterior } \\
\text { - Desenvolvimento do Portal Brasileiro de Comércio } \\
\text { Exterior }\end{array}$ \\
\hline Programa de Exportações & 2001 & $\begin{array}{l}\text { Criado com base no conjunto de medidas } \\
\text { recomendadas pelo PEE. Promoveu a implementação } \\
\text { de diversos projetos: dinamização do crédito à } \\
\text { exportação, redução do imposto de renda de remessas } \\
\text { ao exterior para promoção comercial, implantação do } \\
\text { sistema de exportação em consignação, crédito } \\
\text { presumido de PIS e COFINS para produtos de } \\
\text { exportação, criação de aeroportos aduaneiros } \\
\text { industriais, criação do "Exporta Fácil" dos Correios, } \\
\text { criação do Programa de Apoio Tecnológico à } \\
\text { Exportação - PROGEX. }\end{array}$ \\
\hline
\end{tabular}

Fonte: Mensagens ao Congresso Nacional de 1995 a 2002.

Cabe também destacar as inovações burocráticas, com a criação da CAMEX, já mencionada, e de uma Agência de Promoção de Exportações (APEX), ligada ao SEBRAE. O diferencial da APEX foi que, diferentemente do que ocorria com outros órgãos do governo que atuavam na promoção comercial - como a Secretaria de Comércio Exterior do MDIC, o Departamento de Promoção Comercial do MRE e as próprias Seções de Promoção Comercial das Embaixadas -, ela disporia de orçamento próprio especificamente destinado à promoção comercial. Contudo, como o SEBRAE atendia apenas pequenas empresas, a atuação da APEX também ficou limitada a esse nicho empresarial. "Para flexibilizar essa regra, a Apex foi autorizada a incluir empresas de médio e grande portes em seus programas, desde que tal inclusão gere comprovadamente benefícios para empresas de menor porte" (VEIGA; RIOS, 2009, p. 63).

Por fim, ainda no final do governo FHC, em 2002, foi criado o Programa de Apoio a Investimentos de Empresas Brasileiras de Capital Nacional no Exterior, com o objetivo de apoiar a internacionalização de empresas brasileiras, o qual atendeu a demandas de empresas do setor exportador. Os custos do programa eram suportados pelo BNDES.

O governo FHC, portanto, foi um período de estruturação de novos mecanismos de coordenação da política comercial. Foi marcado pela recomposição e ampliação dos mecanismos de financiamento e de desoneração tributária das exportações, pela criação de órgãos preocupados com a política comercial e com a promoção de 
exportações - a CAMEX e a APEX. Apesar disso, pode-se dizer que foram anos de conflitos burocráticos - sobretudo entre MDIC e MF - a respeito da política comercial e de avanços e retrocessos em relação às características e competências da CAMEX. Não fossem esses aspectos, os resultados institucionais do período poderiam ter sido ainda mais positivos para o comércio exterior brasileiro.

\subsection{O governo PT e a conformação das características institucionais atuais}

O governo do Presidente Luiz Inácio Lula da Silva (Lula), do Partido dos Trabalhadores (PT), foi marcado pela elevação de patamar da política externa do país, o que refletiu na política de comércio exterior do Brasil. Segundo destacaram Veiga e Rios (2009, p. 30) "o governo Lula amplia o grau de ambição da política externa e impõe uma mudança relevante na relação de funcionalidade entre as políticas externa e comercial brasileiras em comparação com o período anterior". Por isso, a grande maioria das análises sobre o comércio exterior brasileiro durante o governo Lula concentram-se nas ações de política externa.

Apesar disso, foram desenvolvidas duas políticas públicas voltadas ao desenvolvimento industrial e do comércio exterior: a Política Industrial, Tecnológica e de Comércio Exterior (PITCE), que vigorou durante o primeiro mandato; e a Política de Desenvolvimento Produtivo (PDP), adotada no segundo mandato.

A PITCE constituiu uma política voltada para o setor produtivo, que teve por objetivo fomentar o desenvolvimento industrial e a inovação tecnológica a fim de aumentar a competitividade da indústria e do produto nacional no exterior. A PITCE foi articulada em torno de três eixos: linhas de ação horizontal, opções estratégicas e atividades portadoras de futuro, cada um deles dividido em algumas frentes de ação. A inserção internacional foi inserida no eixo das ações horizontais, juntamente com inovação e desenvolvimento tecnológico, modernização industrial e melhoria do ambiente institucional. Entre as opções estratégicas foram escolhidos os setores de semicondutores, softwares, bens de capital e fármacos e medicamentos. Já as atividades portadoras de futuro foram direcionadas para biotecnologia, nanotecnologia, biomassa e energias renováveis. O comércio exterior, que faz parte do objetivo de inserção externa do eixo de ações horizontais, foi desenvolvido sob o amparo do 
Programa Brasil Exportador, o qual orientou a política de comércio exterior ao longo do primeiro mandato do Presidente Lula.

Já a PDP teve por objetivo ampliar e aprofundar as políticas estruturantes introduzidas pela PITCE. Os quatro objetivos centrais estabelecidos para a PDP foram: ampliar a capacidade produtiva doméstica, preservar a robustez do balanço de pagamentos, elevar a capacidade de inovação do setor privado e fortalecer micro e pequenas empresas. Para cada um dos objetivos, foram fixadas macrometas para 0 ano de 2010, a fim de coordenar as expectativas dos agentes e permitir o monitoramento dos resultados. Uma das macrometas estabelecidas foi o aumento da participação brasileira nas exportações mundiais de 1,16\% (2007) para 1,25\% (2010) (LULA DA SILVA, 2009, pp. 25-26).

Como resultado dessas duas políticas amplas, foram lançados programas e adotadas diversas medidas de fomento à exportação, como a simplificação normativa, o aperfeiçoamento de procedimentos administrativos de exportação, a criação de ferramentas de monitoramento do comércio exterior e ampliação e simplificação do sistema de crédito e garantia para exportações Os programas trataram não apenas da atividade exportadora, mas também da competitividade das cadeias produtivas e da aproximação entre governo federal e governos estaduais na promoção da atividade exportadora.

Em relação a financiamento e garantia, ocorreram mudanças de legislação e criação de novos órgãos que ampliaram e simplificaram o acesso a esses instrumentos, além de terem sido ampliados os recursos empregados nos programas de financiamento público. Foram, também, adotadas medidas de desoneração tributária, com destaque para desoneração de insumos adquiridos no mercado interno para fabricação de mercadorias para exportação (drawback verde-amarelo). Nesse aspecto, contudo, as medidas não foram tão numerosas nem abrangentes quanto no governo FHC.

O Quadro 2 a seguir apresenta as ações e os programas adotados ao longo do governo Lula com vistas a fomentar o comércio exterior brasileiro e fomentar seus mecanismos operacionais: 
Quadro 2 - Programas e ações de fomento à exportação durante o governo Lula

\begin{tabular}{|c|c|c|c|}
\hline & Programas e ações & Ano & Descrição \\
\hline \multirow{3}{*}{ 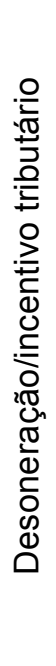 } & $\begin{array}{l}\text { Criação do Regime } \\
\text { REPORTO }\end{array}$ & 2004 & $\begin{array}{l}\text { Regime tributário de incentivo à modernização e } \\
\text { ampliação da estrutura portuária, o que facilitará o } \\
\text { escoamento das mercadorias nacionais para os } \\
\text { mercados externos. }\end{array}$ \\
\hline & $\begin{array}{l}\text { Edição da Lei n. } 11.774 \text { de } \\
2008\end{array}$ & 2008 & $\begin{array}{l}\text { Lei que disciplina o alcance de benefícios fiscais para } \\
\text { o setor exportador, incluindo a contratação de } \\
\text { serviços e de logística no exterior e a possibilidade de } \\
\text { utilização de recursos no exterior para o pagamento } \\
\text { de despesas. }\end{array}$ \\
\hline & $\begin{array}{l}\text { Regulamentação do } \\
\text { Drawback Verde-Amarelo }\end{array}$ & 2008 & $\begin{array}{l}\text { Regime tributário que permite a suspensão dos } \\
\text { tributos federais indiretos incidentes sobre a } \\
\text { aquisição de insumos nacionais utilizados na } \\
\text { fabricação de mercadorias para exportação. }\end{array}$ \\
\hline \multirow{6}{*}{ 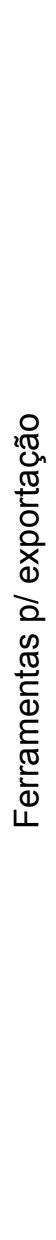 } & $\begin{array}{l}\text { Criação da ferramenta Alerta } \\
\text { Exportador }\end{array}$ & 2003 & $\begin{array}{l}\text { Ferramenta gratuita, via internet, por meio da qual o } \\
\text { exportador brasileiro é informado a respeito de } \\
\text { notificações que importadores de produtos brasileiros } \\
\text { tenham apresentado à OMC sobre regulamentos } \\
\text { técnicos e outras exigências. }\end{array}$ \\
\hline & $\begin{array}{l}\text { Mudanças no SISCOMEX- } \\
\text { Exportação }\end{array}$ & 2004 & $\begin{array}{l}\text { Simplificação no Registro de Exportação (RE) e } \\
\text { outras mudanças destinadas a simplificar e agilizar as } \\
\text { operações de exportação. Tornou a interface com o } \\
\text { usuário mais fácil e interativa. }\end{array}$ \\
\hline & $\begin{array}{l}\text { Criação do Portal do } \\
\text { Exportador }\end{array}$ & 2004 & $\begin{array}{l}\text { Portal criado para facilitar a inserção das micro, } \\
\text { pequenas e médias empresas no mercado } \\
\text { internacional. Disponibiliza informações sobre o } \\
\text { processo de exportação e pesquisas de mercado. }\end{array}$ \\
\hline & $\begin{array}{l}\text { Criação do serviço Fala } \\
\text { Exportador }\end{array}$ & 2004 & $\begin{array}{l}\text { Serviço de } 0800 \text { para atender ligações de quem não } \\
\text { tem acesso à internet, com a finalidade de tirar } \\
\text { dúvidas sobre comércio exterior. }\end{array}$ \\
\hline & $\begin{array}{l}\text { Desenvolvimento do } \\
\text { SISCOMEX-Exportação Web }\end{array}$ & 2006 & $\begin{array}{l}\text { Nova plataforma do SISCOMEX, com o objetivo de } \\
\text { conferir maior agilidade e simplicidade às etapas do } \\
\text { processo operacional de exportação. Passou a } \\
\text { permitir que as operações sejam registradas e } \\
\text { analisadas on line pelos órgãos gestores e anuentes } \\
\text { do comércio exterior. }\end{array}$ \\
\hline & $\begin{array}{l}\text { Lançamento de nova versão } \\
\text { do Portal do Exportador }\end{array}$ & 2007 & Aperfeiçoamento da ferramenta. \\
\hline
\end{tabular}




\begin{tabular}{|c|c|c|c|}
\hline \multirow{8}{*}{ 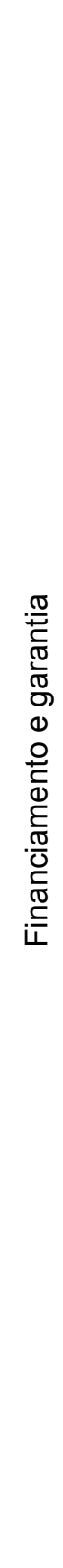 } & $\begin{array}{l}\text { Criação do Comitê de } \\
\text { Financiamento e Garantia das } \\
\text { Exportações (COFIG) }\end{array}$ & 2003 & $\begin{array}{l}\text { Resultante da unificação do Conselho Diretor do } \\
\text { Fundo de Garantia à Exportação (CFGE) e do Comitê } \\
\text { de Crédito à Exportação (CCEX). A mudança } \\
\text { aumentou a agilidade na resposta ao pleito dos } \\
\text { exportadores. O COFIG examina e delibera sobre } \\
\text { pleitos de operações de PROEX (financiamento ou } \\
\text { equalização) e de Seguro de Crédito à Exportação. }\end{array}$ \\
\hline & $\begin{array}{l}\text { Criação do Programa de } \\
\text { Incentivo à Produção } \\
\text { Exportável de Pequenas e } \\
\text { Médias Empresas - PROPEX }\end{array}$ & 2003 & $\begin{array}{l}\text { Programa viabilizado pelo Tesouro Nacional, para } \\
\text { solucionar a dificuldade na prestação de garantias } \\
\text { exigida pelos bancos. }\end{array}$ \\
\hline & $\begin{array}{l}\text { Inclusão dos organismos } \\
\text { financeiros internacionais no } \\
\text { PROEX-Equalização }\end{array}$ & 2003 & $\begin{array}{l}\text { Ampliação das oportunidades de crédito do } \\
\text { programa. }\end{array}$ \\
\hline & $\begin{array}{l}\text { Revisão do seguro de crédito } \\
\text { nas operações com o } \\
\text { Convênio de Pagamentos e } \\
\text { Créditos Recíprocos (CCR) }\end{array}$ & 2003 & $\begin{array}{l}\text { Mudança na classificação das operações financiadas } \\
\text { pelo Proex ou pelo BNDES, para efeitos de seguro de } \\
\text { crédito, aumentando a competitividade das } \\
\text { exportações brasileiras }\end{array}$ \\
\hline & $\begin{array}{l}\text { Revogação nos limites de } \\
\text { valores e prazos para uso do } \\
\text { CCR }\end{array}$ & 2003 & Ampliação e facilitação do crédito. \\
\hline & $\begin{array}{l}\text { Aumento dos recursos do } \\
\text { Fundo de Garantia à } \\
\text { Exportação (FGE) }\end{array}$ & 2003 & $\begin{array}{l}\text { Aumento de US } \$ 1,7 \text { bi para US } \$ 3,5 \text { bi de } 2002 \text { para } \\
2003 \text {. }\end{array}$ \\
\hline & $\begin{array}{l}\text { Alterações no } \\
\text { PROEX/Financiamento }\end{array}$ & 2008 & $\begin{array}{l}\text { Extensão do programa para fase de produção de } \\
\text { bens e serviços para exportação (pré-embarque) e } \\
\text { alteração dos critérios para enquadramento das } \\
\text { empresas, aumentando o limite de faturamento de } R \$ \\
150 \text { milhões para } R \$ 300 \text { milhões. }\end{array}$ \\
\hline & $\begin{array}{l}\text { Alteração na legislação do } \\
\text { Seguro de Crédito à } \\
\text { Exportação }\end{array}$ & 2008 & $\begin{array}{l}\text { Possibilitou à União conceder garantia a micro, } \\
\text { pequenas e médias empresas, nas fases de pré e } \\
\text { pós-embarque, suprindo lacuna de mercado para } \\
\text { esse segmento empresarial. }\end{array}$ \\
\hline 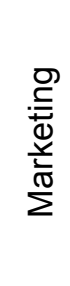 & Promoção da Marca Brasil & 2003 & $\begin{array}{l}\text { Ações promovidas pelo MDIC e pela APEX no } \\
\text { sentido de criar uma marca Brasil e divulgá-la no } \\
\text { exterior. Contemplou a campanha promocional We do } \\
\text { it different, divulgada feiras, missões e eventos } \\
\text { comerciais, destinada a divulgar a marca Brasil e } \\
\text { aumentar o potencial de negócios do país no exterior. }\end{array}$ \\
\hline
\end{tabular}




\begin{tabular}{|c|c|c|c|}
\hline \multirow{2}{*}{ 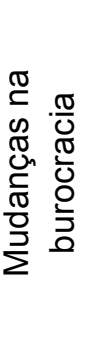 } & Criação da APEX-Brasil & 2003 & $\begin{array}{l}\text { Agência de Promoção de Exportações Brasileiras, } \\
\text { com fonte de recursos permanente e autonomia para } \\
\text { realizar ações de promoção comercial do Brasil em } \\
\text { mercados externos. }\end{array}$ \\
\hline & Reestruturação da CAMEX & 2003 & $\begin{array}{l}\text { Inclusão de cinco ministérios no Grupo Gestor da } \\
\text { Câmara e criação de Conselhos Empresariais } \\
\text { Consultivos. }\end{array}$ \\
\hline 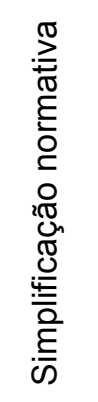 & $\begin{array}{l}\text { Consolidação e simplificação } \\
\text { de atos normativos }\end{array}$ & 2004 & $\begin{array}{l}\text { Consolidação de } 83 \text { atos normativos de comércio } \\
\text { exterior em um único ato. }\end{array}$ \\
\hline \multirow{4}{*}{ 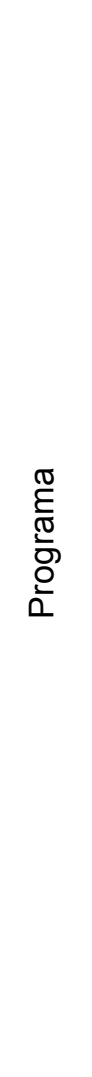 } & Programa Brasil Exportador & 2003 & $\begin{array}{l}\text { Integrou a PITCE, lançada no início do governo. } \\
\text { Compreendia medidas de curto prazo que pretendiam } \\
\text { ter alto impacto no processo de exportação. Meta: } \\
\text { alcançar o valor de US } \$ 100 \text { bilhões de exportações } \\
\text { em } 2006 \text {. }\end{array}$ \\
\hline & $\begin{array}{l}\text { Ampliação de programas } \\
\text { estaduais: Programa de } \\
\text { Expansão Industrial } \\
\text { Exportadora (PEIEX) e } \\
\text { Programa Estado Exportador }\end{array}$ & 2005 & $\begin{array}{l}\text { Ações com o objetivo de ampliar a participação de } \\
\text { estados e municípios nas ações do governo federal } \\
\text { de promoção do comércio exterior. Ampliação dos } \\
\text { programas para abranger todos os estados do } \\
\text { Federação. }\end{array}$ \\
\hline & $\begin{array}{l}\text { Programa Competitividade } \\
\text { das Cadeias Produtivas }\end{array}$ & 2007 & $\begin{array}{l}\text { Programa com o objetivo de elevar a competitividade } \\
\text { das principais cadeias produtivas do país, com efeitos } \\
\text { sobre as exportações. O diálogo entre as cadeias } \\
\text { produtivas e o setor público é promovido por meio } \\
\text { dos Fóruns de Competitividade. }\end{array}$ \\
\hline & Programa Revitaliza & 2007 & $\begin{array}{l}\text { Incluiu, entre outras medidas, o aumento das linhas } \\
\text { de crédito para exportação dos setores de calçados, } \\
\text { artefatos de couro, pedras ornamentais, têxtil, } \\
\text { confecções e móveis. }\end{array}$ \\
\hline
\end{tabular}




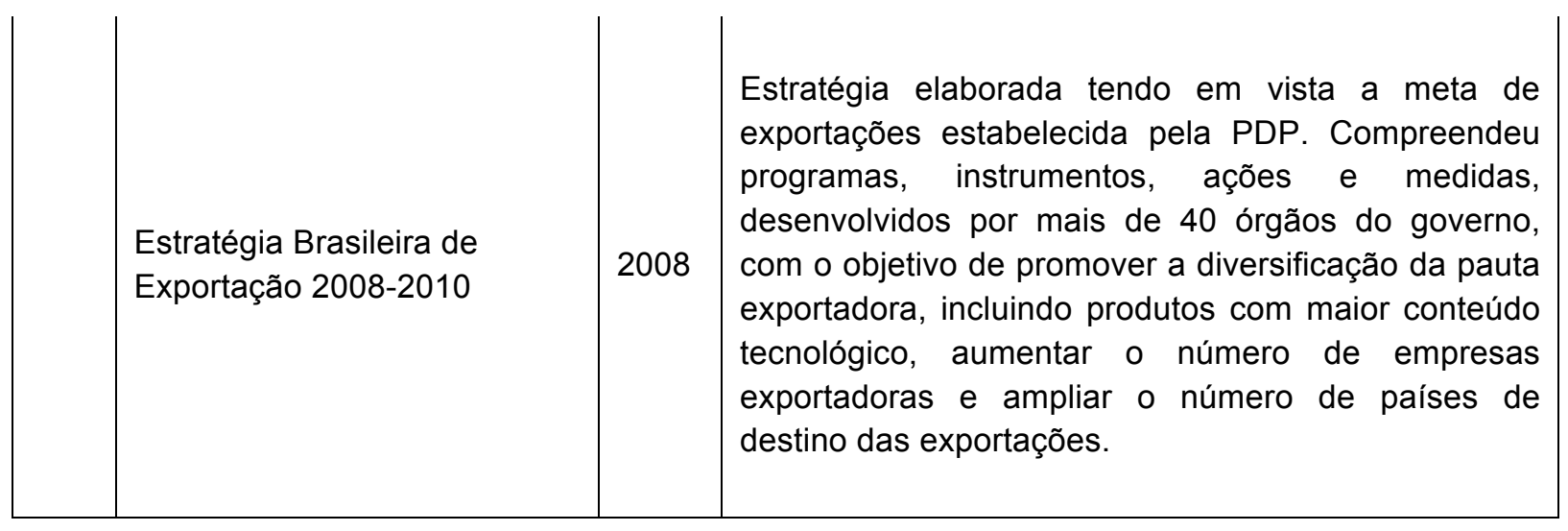

Fonte: Mensagens ao Congresso Nacional de 2003 a 2010.

Sobre a CAMEX, foram mantidas as principais características do governo FHC, com a diferença de que, logo no início do governo Lula, foi restituída à Câmara sua competência para formulação da política comercial (excluída em 2001) ${ }^{19}$. Cabe mencionar que a CAMEX foi mantida como parte da estrutura do MDIC e sendo presidida por esse Ministério, ao qual também foi atribuída a competência para nomear o secretário executivo da CAMEX. Em relação às decisões da Câmara, foram mantidas as resoluções vinculantes, mas a forma de deliberação foi alterada de consenso para maioria. Ademais, foi durante o mandato do Presidente Lula que o Ministério do Desenvolvimento Agrário (MDA) ingressou no Conselho de Ministros, representando os interesses da agricultura familiar e fazendo um contraponto aos interesses da indústria, representados pelo MDIC.

Para Fernandes (2010), embora a recuperação da competência de formulação tenha representado um ganho de prestígio e de poder para o MDIC, na prática, não foi possível superar as divergências com o Ministério da Fazenda e os demais ministérios no âmbito da CAMEX - "com a permanência das ambiguidades institucionais decorrentes de sua alocação no MDIC, sua capacidade de ser o locus de articulação de uma estratégia global de comércio exterior foi reduzida a um nível de coordenação menos político e mais técnico" (FERNANDES, 2010, p. 114). Com relação às deliberações por maioria, embora se esperasse que a mudança conferisse mais

19 O Decreto $n^{\circ}$. 4.732, de 10 de setembro de 2003, estabeleceu como objetivos da CAMEX: formulação, adoção, implementação e coordenação de políticas e atividades relativas ao comércio exterior de bens e serviços, incluindo o turismo. Esse decreto está atualmente vigente e é o instrumento que regulamenta as competências e atividades da CAMEX. 
efetividade às reuniões do Conselho de Ministros, o autor afirma que, na realidade, raras vezes os temas são levados à votação na CAMEX.

Cabe destacar, por fim, que o quadro de servidores da carreira de analista de comércio exterior, própria do MDIC, foi consideravelmente ampliado durante os dois mandatos do governo Lula, o que propiciou o fortalecimento da carreira e do ministério e vem possibilitando a realização de trabalhos técnicos cada vez mais especializados. Além disso, foram também ampliados os quadros técnicos da CAMEX, sobretudo com a alocação de analistas de comércio exterior e com o aumento de cargos de assessoria em sua estrutura.

O primeiro mandato do governo Dilma, também do $\mathrm{PT}$, teve início em janeiro de 2011 e deparou com condições internas e externas diversas das que haviam prevalecido no durante o governo Lula. As discussões sobre a manipulação das taxas de câmbio e as incertezas sobre a recuperação das economias afetadas pela crise de 2008 centralizaram os debates da política econômica e provocaram preocupações quanto à situação do comércio exterior brasileiro. O aumento das importações, decorrente do real valorizado, e a perda de participação dos produtos industrializados na pauta de exportação inquietavam o setor industrial brasileiro, e a preocupação com a possível substituição de produtos domésticos por mercadorias importadas levou a um arrefecimento das demandas protecionistas por parte da indústria nacional. Ademais, Barral e Bohrer (2011) ressaltam que o governo Dilma encontrava-se em um momento de paralisia e falta de perspectiva nas negociações internacionais - tanto no plano multilateral quanto no MERCOSUL -, levando o governo optar pelas estratégias de defesa da indústria e promoção comercial.

O resultado dessa conjuntura foi o aumento das medidas protecionistas já no início do primeiro mandato Dilma, tanto por meio de ações pontuais de defesa comercial como pela adoção de programas e medidas tributárias de médio prazo com fins de proteção à indústria nacional. O reflexo dessa orientação pode ser verificado no principal plano econômico lançado no primeiro mandato da Presidente Dilma, o Plano Brasil Maior (PBM), lançado em agosto de 2011.

O PBM foi um plano que compreendeu políticas industriais, tecnológicas e de comércio exterior com o objetivo de promover inovação e adensamento da cadeia produtiva industrial nacional, por meio de medidas de desoneração dos investimentos e das exportações, de aumento do crédito e aperfeiçoamento do marco regulatório sobre inovação. Além disso, o plano previu o fortalecimento dos mecanismos de defesa 
comercial, o que foi feito com aumento expressivo do quadro de funcionários do MDIC dedicados às investigações (de 30 para 150) e implicou a ampliação do uso das medidas antidumping. Sobre os mecanismos protecionistas empregados pelo PBM, Veiga, Rios e Naidin (2013, p. 19) explicam:

\begin{abstract}
Mais do que por meio de mecanismos de proteção contra importações, a discriminação em favor da produção doméstica foi operacionalizada, no PBM, por medidas de estímulo às exportações e aos investimentos e pela adoção de preferências a produtos nacionais nas compras governamentais de bens e serviços. Nessa mesma linha, o PBM intensificou $\mathrm{o}$ uso de mecanismos direcionados ao aumento do conteúdo nacional dos produtos industriais, como o condicionamento de concessão de incentivos fiscais e creditícios ao atendimento de determinado grau de conteúdo doméstico.
\end{abstract}

No mesmo sentido, em 2012, o governo lançou o novo programa de incentivos ao setor automotivo, o Programa Inovar-Auto. Com o objetivo de aumentar a competitividade da indústria nacional, promover o investimento na cadeia de fornecedores e engenharia e incentivar o desenvolvimento de carros mais seguros e econômicos, o programa estabeleceu determinados benefícios tributários para as empresas que cumprissem uma série de pré-requisitos, dentre os quais a obrigatoriedade de realizar certas etapas do processo produtivo no Brasil.

Ainda como parte do Plano Brasil Maior, o governo implantou, em 2011, o Regime Especial de Reintegração de Valores Tributários para Empresas Exportadoras (Reintegra), que consistiu - e consiste - na devolução de créditos tributários residuais incidentes ao longo da cadeia produtiva de produtos exportados. O Reintegra constitui um mecanismo importante de desoneração das mercadorias de exportação, que foi considerado, pela indústria nacional, como essencial para aumentar a competitividade das exportações brasileiras no exterior. Contudo, diante da crise fiscal que vem se agravando ao longo dos mandatos Dilma, o governo não foi capaz de sustentar o percentual inicial de recuperação do Reintegra, que era de 3\% e atualmente, em 2016, se encontra em $0,1 \%$.

Ademais das ações adotadas ao amparo do PBM, o Quadro 3 abaixo apresenta um resumo das ações domésticas empreendidas durante o primeiro mandato do governo Dilma em prol do desenvolvimento do comércio exterior brasileiro. Nota-se que a maior parte das ações do governo Dilma concentrou-se na criação e no aperfeiçoamento das ferramentas de comércio exterior, tendo havido poucas iniciativas 
no que se refere à desoneração tributária e outros aspectos importantes para a competitividade das exportações brasileiras.

Quadro 3 - Programas e ações de fomento à exportação durante o primeiro mandato do governo Dilma Rousseff

\begin{tabular}{|c|c|c|c|}
\hline & Programas e ações & Ano & Descrição \\
\hline \multirow{3}{*}{ 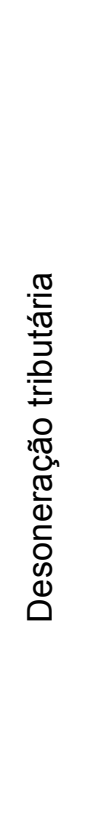 } & $\begin{array}{l}\text { Instituição do regime } \\
\text { Reintegra }\end{array}$ & 2011 & $\begin{array}{l}\text { Regime Especial de Reintegração de Valores } \\
\text { Tributários para Empresas Exportadoras - crédito } \\
\text { tributário, calculado sobre o valor exportado pela } \\
\text { empresa, a título de recuperação de resíduo tributário } \\
\text { sobre a cadeia produtiva. }\end{array}$ \\
\hline & $\begin{array}{l}\text { Aceleração do ressarcimento } \\
\text { de crédito aos exportadores }\end{array}$ & 2011 & $\begin{array}{l}\text { Aceleração do ressarcimento para exportadores com } \\
\text { processamento automático, com pagamento até } 60 \\
\text { dias. }\end{array}$ \\
\hline & $\begin{array}{l}\text { Entrada em vigor do } \\
\text { Drawback Integrado Isenção }\end{array}$ & 2011 & $\begin{array}{l}\text { Isenção do II e redução a zero do IPI e do PIS/Cofins } \\
\text { incidentes nas importações e aquisições no mercado } \\
\text { interno de mercadoria equivalente à empregada ou } \\
\text { consumida na industrialização de produto exportado - } \\
\text { a novidade no mecanismo já existente foi a } \\
\text { possibilidade de poder adquirir com benefício fiscal } \\
\text { mercadoria para repor o produto nacional utilizado na } \\
\text { produção de mercadoria já exportada. }\end{array}$ \\
\hline \multirow{3}{*}{ 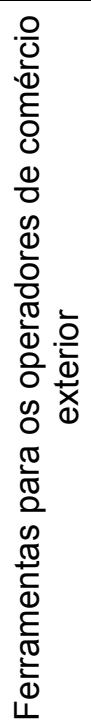 } & $\begin{array}{l}\text { Lançamento da versão } 2 \text { do } \\
\text { AliceWeb }\end{array}$ & 2011 & $\begin{array}{l}\text { 2a versão da ferramenta Análise de Informações de } \\
\text { Comércio Exterior - sistema de divulgação de } \\
\text { estatístitcas de comércio exterior -, com melhoria na } \\
\text { acessibilidade e incremento nas variáveis, que } \\
\text { passaram a incluir dados municipais. }\end{array}$ \\
\hline & $\begin{array}{l}\text { Conclusão da 2a versão do } \\
\text { Radar Comercial }\end{array}$ & 2011 & $\begin{array}{l}\text { 2a versão do sistema de inteligência comercial que } \\
\text { auxilia na identificação de oportunidades para } \\
\text { produtos brasileiros no exterior, com } \\
\text { aperfeiçoamentos para a navegação e inclusão de } \\
\text { novos países. }\end{array}$ \\
\hline & $\begin{array}{l}\text { Lançamento da Balança } \\
\text { Comercial de Cooperativas }\end{array}$ & 2011 & $\begin{array}{l}\text { Boletim de periodicidade mensal que apresenta a } \\
\text { evolução dos principais produtos importados e } \\
\text { exportados e dos mercados compradores e } \\
\text { fornecedores. }\end{array}$ \\
\hline
\end{tabular}




\begin{tabular}{|c|c|c|c|}
\hline & $\begin{array}{l}\text { Lançamento do Portal } \\
\text { Brasileiro de Comércio } \\
\text { Exterior (PBCE) }\end{array}$ & 2011 & $\begin{array}{l}\text { Substituiu o Portal do Exportador e ampliou o } \\
\text { conteúdo disponível, incluindo informações sobre } \\
\text { importação. }\end{array}$ \\
\hline & $\begin{array}{l}\text { Reformulação da Vitrine do } \\
\text { Exportador }\end{array}$ & 2011 & $\begin{array}{l}\text { As mudanças passaram a permitir maior } \\
\text { interatividade e a criação de vitrines virtuais } \\
\text { individualizadas para os exportadores. }\end{array}$ \\
\hline & Implantação do Novoex & 2012 & $\begin{array}{l}\text { Corresponde ao Siscomex Exportação Web. Assumiu } \\
\text { a totalidade das operações de exportação. }\end{array}$ \\
\hline & Lançamento do Capta & 2012 & $\begin{array}{l}\text { Consulta aos Acordos de Preferências Tarifárias - } \\
\text { ferramenta que permite consulta a informações sobre } \\
\text { tratamento preferencial concedido pelo Brasil a } 44 \\
\text { países e sobre o tratamento preferencial recebido } \\
\text { pelo Brasil de } 37 \text { países. Facilita a divulgação de } \\
\text { acordos comerciais brasileiros. }\end{array}$ \\
\hline & $\begin{array}{l}\text { Lançamento do Simulador de } \\
\text { Preço de Exportação }\end{array}$ & 2013 & Ferramenta para auxiliar o exportador. \\
\hline & $\begin{array}{l}\text { Lançamento do sistema } \\
\text { eletrônico de processamento } \\
\text { do drawback isenção }\end{array}$ & 2014 & $\begin{array}{l}\text { Faz parte das entregas de um projeto maior de single } \\
\text { window para o comércio exterior brasileiro } \\
\text { denominado Portal Único de Comércio Exterior. }\end{array}$ \\
\hline & $\begin{array}{l}\text { Criação do Fundo de } \\
\text { Financiamento à Exportação } \\
\text { de MPME }\end{array}$ & 2011 & $\begin{array}{l}\text { Fundo destinado a atender micro, pequenas e médias } \\
\text { empresas. }\end{array}$ \\
\hline 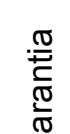 & $\begin{array}{l}\text { Cobertura do FGE para } \\
\text { exportações a países de } \\
\text { maior risco }\end{array}$ & 2011 & $\begin{array}{l}\text { Cobertura a operações de exportação para países de } \\
\text { maior risco com recursos do Fundo Garantidor de } \\
\text { Crédito. }\end{array}$ \\
\hline 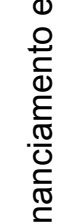 & Criação da ABGF & 2012 & $\begin{array}{l}\text { Agência Brasileira Gestora de Fundos e Garantias } \\
\text { S.A. Objetiva facilitar e aumentar o acesso ao crédito } \\
\text { pelos diversos agentes econômicos. O governo } \\
\text { pretende operar nos nichos nos quais o setor privado } \\
\text { tenha pouco interesse. }\end{array}$ \\
\hline & $\begin{array}{l}\text { Nova modalidade de Seguro } \\
\text { de Crédito à Exportação }\end{array}$ & 2014 & $\begin{array}{l}\text { Modalidade garantida pelo FGE para oferecer } \\
\text { cobertura de risco político extraordinário para } \\
\text { operações de financiamento de curto prazo para } \\
\text { exportações destinadas ao continente africano. }\end{array}$ \\
\hline
\end{tabular}




\begin{tabular}{|c|c|c|c|}
\hline \multirow{2}{*}{ 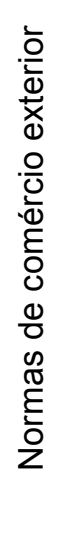 } & $\begin{array}{l}\text { Esforço para consolidação da } \\
\text { legislação de comércio }\end{array}$ & 2011 & Medidas diversas. \\
\hline & Revisão das anuências & 2013 & $\begin{array}{l}\text { Realização de processo de revisão das anuências } \\
\text { necessárias para exportação. }\end{array}$ \\
\hline $\begin{array}{l}\frac{\pi}{c} \\
\frac{\pi}{6} \\
\frac{0}{2} \\
\frac{0}{2}\end{array}$ & $\begin{array}{l}\text { Lançamento do Plano } \\
\text { Nacional da Cultura } \\
\text { Exportadora }\end{array}$ & 2012 & $\begin{array}{l}\text { Plano destinado à construção de Mapas Estratégicos } \\
\text { de Comércio Exterior, com a finalidade de constituir } \\
\text { uma política de comércio exterior para cada unidade } \\
\text { da federação. }\end{array}$ \\
\hline \multirow[b]{2}{*}{ 西 } & $\begin{array}{l}\text { Aperfeiçoamento da } \\
\text { legislação das ZPEs }\end{array}$ & 2011 & $\begin{array}{l}\text { Legislação referente às Zonas de Processamento de } \\
\text { Exportação }\end{array}$ \\
\hline & $\begin{array}{l}\text { Reformulação e flexibilização } \\
\text { das normas do Programa } \\
\text { Mais Alimentos }\end{array}$ & 2013 & $\begin{array}{l}\text { Programa que objetiva incentivar a exportação } \\
\text { brasileira de máquinas e equipamentos agrícolas. As } \\
\text { mudanças visam conferir mais celeridade às } \\
\text { operações. }\end{array}$ \\
\hline
\end{tabular}

Fonte: Mensagens ao Congresso Nacional de 2012 a 2015.

Além disso, Barral e Bohrer (2011) destacam uma série de medidas administrativas adotadas pelo governo para aprofundar o trabalho da diplomacia e da promoção comercial. Uma delas foi a realização de acordo entre o Itamaraty e a AGU com vistas a melhorar a formação jurídica dos negociadores brasileiros e sua preparação específica em relação aos contenciosos comerciais. Outras medidas foram o aumento do número de Setores de Promoção Comercial (SECOMs) situados nas Embaixadas, a criação de um Força-Tarefa sobre China na Subsecretaria Geral de Assuntos Econômicos e Financeiros do Itamaraty (SGEF) e os programas de capacitação para operadores do comércio exterior brasileiro.

Em essência, o governo Dilma adotou uma estratégia defensiva de comércio exterior, baseada em medidas de defesa comercial e no protecionismo da indústria nacional, por meio das exigências de conteúdo nacional e das margens de preferência para compras governamentais. Além disso, foi um governo que promoveu o distanciamento do Brasil dos foros comerciais internacionais, não só relegando qualquer posição de protagonismo nas negociações, mas também - afirmam muitos analistas - 
afrontando princípios do sistema multilateral de comércio com as medidas protecionistas e de favorecimento da indústria nacional adotadas. Além disso, ao mesmo tempo em que procurou estimular o adensamento das cadeias produtivas nacionais, acabou por afastar o país da inserção nas cadeias globais de valor.

Em vista disso, Veiga, Rios e Naidin (2013, p. 20) concluem que:

Ficara claro que as medidas de política industrial e comercial até então adotadas não lograram cumprir o papel a elas atribuído pela estratégia de crescimento baseada no consumo doméstico: garantir que os benefícios daquela expansão não fossem capturados pelas importações, mas sim pela produção doméstica. A consequência foi a volta à agenda do (até então ausente na agenda de políticas públicas) tema da falta de competitividade e da baixa e pouco dinâmica produtividade da indústria.

Ocorre que, como destacam Barral e Bohrer (2011, p. 121), “implementar medidas para competitividade enfrenta, ademais, dificuldades institucionais que não foram criadas pelo governo Rousseff". Questões como eficiência logística, redução da burocracia, estrutura tributária e tarifária, falta de coordenação entre os ministérios e entre os agentes da promoção comercial e da atração de investimentos, entre outros, são problemas de longa data que afetam a competitividade da indústria nacional e do exportador brasileiro. Eles certamente exigirão mais do que um mandato presidencial e muito mais do que ações pontuais para serem enfrentados, eles demandarão uma mudança de mentalidade e de objetivos políticos.

Nem todos esses problemas estão diretamente associados ao que estamos considerando, neste trabalho, como matriz institucional do comércio exterior brasileiro, mas parte deles está. Ao final do capítulo 4, esperamos ter um diagnóstico mais claro sobre eles.

\subsection{O governo interino e as mudanças na governança do comércio exterior}

O recente afastamento da Presidente Dilma Rousseff, que decorreu da decisão do Senado Federal que decidiu, no dia 12 de maio de 2016, receber e dar seguimento ao processo de impeachment aprovado pela Câmara, implicou o início de um governo interino comandado pelo Vice-Presidente Michel Temer, do PMDB. Entre as primeiras medidas tomadas pelo governo interino esteve a realização de uma reforma ministerial, 
que impôs importantes modificações com relação às burocracias com competências de comércio exterior $^{20}$.

Como principais modificações trazidas pela reforma, cabe destacar a migração da presidência da CAMEX para o próprio Presidente da República e de sua Secretaria Executiva para o MRE, ambas a cargo do MDIC até então. Além disso, a APEX deixou de ser entidade vinculada ao MDIC para vincular-se ao MRE, assim como o BNDES se desvinculou do MDIC e passou para a competência do Ministério do Planejamento, que teve sua denominação alterada para Ministério do Planejamento, Desenvolvimento e Gestão. Com isso, o MDIC também deverá ter seu nome alterado para Ministério da Indústria, Comércio Exterior e Serviços (com a sigla ainda indefinida).

Embora o MDIC tenha formalmente mantido todas as suas competências, o fato de ter perdido duas importantes entidades vinculadas, além da presidência e da Secretaria Executiva da CAMEX, representam um importante desprestígio para um ministério considerado central na formulação e execução da política comercial. Ainda não está claro como essas mudanças serão processadas, mas o MDIC certamente sofrerá com a redução de controle sobre esses importantes órgãos executores da política comercial.

Com relação à migração da CAMEX para a Presidência da República, entendemos que a mudança pode representar um elevação do status da Câmara de fato, já que as reuniões coordenadas pelo Presidente terão mais apelo à participação ativa dos ministros do colegiado e deverão ter maior possiblidade de equacionamento dos posicionamentos ministeriais divergentes. A atribuição de sua Secretaria Executiva ao MRE, contudo, significa mudar a operacionalidade da Câmara de um ministério eminentemente técnico e treinado na operacionalidade do comércio exterior para um ministério com características de cunho mais político, e não necessariamente imprimirá imparcialidade à condução dos trabalhos. Se a intenção é fortalecer e tornar a Secretaria Executiva um órgão independente de influências desproporcionais de algum dos Ministérios que compõem a CAMEX, entendemos que o mais adequado seria sua migração para a Presidência da República, da mesma maneira que a presidência do colegiado.

\footnotetext{
20 A reforma foi estabelecida pela Medida Provisória $\mathrm{n}^{\circ} .726$, de 12 de maio de 2016 . Conforme estabelecido pelo art. $62, \S 3^{\circ}$ da $\mathrm{CF} / 88$, as medidas provisórias têm um prazo de 60 dias para serem convertidas em lei, prorrogável uma vez por igual período. Não sendo convertida e extinto o prazo, perde a vigência a medida provisória.
} 
Enfim, trata-se de um governo provisório e de mudanças que foram introduzidas por meio de medida provisória, a qual perderá a vigência no prazo de 60 dias (prorrogável por período de igual período) se não for convertida em lei pelo Congresso Federal. Por isso, ainda não se sabe exatamente se todas essas mudanças permanecerão, como serão operacionalizadas e as consequências práticas que terão para a formulação e execução da política comercial, muito menos quais serão os efeitos práticos de médio e longo prazo sobre os fluxos comerciais do país. O que se pode concluir, não obstante, é que a governança do comércio exterior brasileiro está em fase de reformulação, o que demonstra que o país ainda está longe de atingir a maturidade burocrática necessária para proporcionar estabilidade às instituições. 


\section{A EVOLUÇÃO INSTITUCIONAL EM NÍVEL MUNDIAL: O REGIME INTERNACIONAL DE COMÉRCIO}

Conforme exposto no capítulo 1 deste trabalho, existe um regime internacional de comércio composto por princípios e normas que regem as relações entre os atores nessa área. Esse regime se desdobra em suas dimensões multilateral, representada pela OMC, e regional, que, no caso do Brasil, é constituída pelos acordos regionais de integração. Esse capítulo tem por objetivo apresentar as principais características do regime internacional de comércio nessas duas dimensões, destacando os aspectos e as normas da OMC e do MERCOSUL que serão mais relevantes para as análises das instituições brasileiras que serão realizadas no capítulo 4.

\subsection{O sistema multilateral de comércio}

\subsubsection{Histórico da formação do sistema multilateral de comércio}

O sistema multilateral de comércio é resultado da tentativa dos países aliados, ao Final da Segunda Guerra Mundial, de estabelecer uma ordem internacional capaz de garantir a prevalência do liberalismo, tendo em vista o recrudescimento do protecionismo que o mundo havia vivenciado no período entre guerras.

Ainda antes do fim da guerra, em 1944, as potências aliadas reuniram-se em Bretton Woods, nos Estados Unidos, com o objetivo de discutir uma nova ordem econômica e "criar um ambiente de maior cooperação na área da economia internacional" (THORSTENSEN, 2003, p. 29). Sob a liderança dos Estados Unidos, as principais potências ocidentais, incluindo a Europa Ocidental e o Canadá, mas também o Japão, estabeleceram uma cooperação baseada em motivos econômicos, políticos e ideológicos:

These allies believed that a liberal world economy would meet their economic interests and also solidify their alliance against the Soviet threat. In addition, cooperation was greatly facilitated by the fact that these nations shared an ideological commitment to a liberal international economy based on free trade and open markets. (GILPIN, 2001, p. 86). 
A partir disso, acordou-se a criação de três diferentes organizações internacionais, cada uma destinada a regular uma determinada seara da economia mundial. Uma delas seria o Fundo Monetário Internacional (FMI), ao qual foram atribuídas as funções de manter a estabilidade das taxas de câmbio e auxiliar países com graves problemas de balanço de pagamentos; a outra seria o Banco Internacional de Reconstrução e Desenvolvimento (BIRD), também denominado Banco Mundial, destinado a financiar a reconstrução dos países europeus afetados pela guerra; e a terceira seria a Organização Internacional do Comércio (OIC), responsável pela regulamentação e fiscalização do comércio internacional. Contudo, apenas o FMI e o BIRD foram concretizados, em razão da oposição do Congresso norte-americano em ratificar a Carta de Havana - instrumento que estabelecia a criação da OIC.

Em lugar da OIC, a alternativa possível foi a negociação um acordo provisório, limitado basicamente à negociação de tarifas, assinado em 1947. O acordo, denominado Acordo Geral sobre Tarifas e Comércio (General Agreement on Tariffs and Trade - GATT), foi firmado por 23 países, inclusive os Estados Unidos.

De simples acordo, o GATT se transformou na prática, embora não legalmente, em um órgão internacional, com sede em Genebra, passando a fornecer a base institucional para diversas rodadas de negociações sobre comércio, e a funcionar como coordenador e supervisor das regras de comércio até o final da Rodada Uruguai e a criação da atual OMC. (THORSTENSEN, 2003, p. 30).

A constituição do GATT, embora tenha ficado aquém do objetivo inicial de se estabelecer uma organização internacional, representou o início de um regime internacional de comércio formal, estabelecido por meio de negociações internacionais multilaterais entre Estados, incluindo as principais potências da época ${ }^{21}$.

O GATT vigeu como foro de negociação comercial multilateral e como árbitro das práticas comerciais entre os Estados Partes até 1994, quando então deu lugar à uma organização internacional formalmente constituída, a Organização Mundial do Comércio (OMC). O GATT, contudo, não foi extinto: foi revisado e incorporado ao arcabouço institucional da OMC, tendo sido mantidos os princípios e a maior parte das

21 GILPIN (2001) esclarece que os regimes internacionais podem se desenvolver de duas formas: de forma espontânea, como ocorre com as regras informais, ou de forma consciente, por meio de negociações internacionais entre Estados. Os regimes internacionais monetário e de comércio estabelecidos a partir de Bretton Woods são exemplos da segunda natureza. 
regras de liberalização comercial por ele estabelecidos (os quais serão detalhados mais adiante).

3.1.2 Características gerais e principais marcos normativos do sistema multilateral de comércio atual

O sistema multilateral de comércio é atualmente consubstanciado pela Organização Mundial do Comércio, organização internacional que sucedeu e aperfeiçoou o sistema estabelecido pelo Acordo Geral sobre Tarifas e Comércio, de 1947. O objetivo da OMC, assim como o do GATT, é propiciar o crescimento dos fluxos de comércio internacional, por meio da liberalização comercial. Para isso, a OMC atua na coordenação das negociações comerciais e na supervisão da aplicação das regras (THORSTENSEN, 2003, p. 41).

A OMC é fruto da oitava rodada de negociações no âmbito do GATT, a Rodada do Uruguai, que teve início em 1986 e foi concluída em 1994, em Marraqueche, A ata final da Rodada, conhecida como Acordo de Marraqueche, é composta por diversos anexos, sendo um deles o que estabelece a criação da organização. A época, o acordo constitutivo da OMC foi subscrito por 129 países (PRAZERES, 2008); atualmente (maio de 2016), a organização é composta por 162 membros. A OMC entrou em exercício em $1^{\circ}$ de janeiro de 1995.

Diferentemente do GATT, que não passou de um acordo multilateral visando à liberalização do comércio de bens, a OMC constituiu-se formalmente como uma organização internacional, com personalidade jurídica e estrutura administrativa própria. Além disso, aperfeiçoou o sistema de solução de controvérsias do GATT/1947, alterando o critério de deliberação para a aplicação das decisões dos painéis e instituindo uma instância de apelação, e estabeleceu um mecanismo de revisão de políticas comerciais, que realiza revisões periódicas de todos os membros. Sobre a importância dos avanços empreendidos no sistema multilateral de comércio com a criação da OMC, Prazeres (2008, p. 28) afirma:

Indubitavelmente, o aumento dos fluxos de comércio internacional se beneficiou da liberalização comercial articulada pela OMC. Além de promover a adoção de disciplinas para estimular o comércio de bens e serviços, a OMC constituiu um sistema de monitoramento e controle destinado a garantir a observância dessas regras. Esses elementos 
contribuíram para que se conferisse um mínimo de segurança e previsibilidade às relações entre os membros da Organização, fatores esses de relevância considerável para o incremento do comércio global. Ademais, ao estabelecer compromissos jurídicos internacionais relativos à liberalização comercial, o regime multilateral de comércio evitou que houvesse retrocessos em relação à abertura comercial que se desenvolveu ao longo de décadas.

Com a criação da OMC, outras matérias além do comércio de bens foram incorporadas ao escopo do sistema multilateral de comércio, como serviços, propriedade intelectual, investimentos, aspectos de barreiras não tarifárias, entre outros. Essas matérias estão dispostas sob o guarda-chuva da OMC, mas são objeto de acordos específicos, os quais podem ser de duas naturezas: multilaterais ou plurilaterais. Os acordos multilaterais são aqueles de que fazem parte todos os membros, e qualquer país que deseje aceder à organização terá obrigatoriamente que aderir a todos eles, enquanto os acordos plurilaterais são celebrados apenas por parte dos membros.

São 18 os acordos específicos celebrados ao amparo do acordo constitutivo da OMC, em 1994, dispostos nos 4 anexos da Ata Final da Rodada do Uruguai. Esses acordos dão forma e conteúdo ao sistema multilateral de comércio, estabelecendo tanto as regras comerciais quanto os mecanismos de controle de políticas e de solução de controvérsias no âmbito do sistema. Os 3 primeiros anexos correspondem aos acordos de natureza multilateral - sendo que o Anexo 1 A é composto por 10 acordos, referentes ao comércio de bens -, enquanto o anexo 4 compreende 4 acordos plurilaterais. A composição completa dos anexos da Ata Final da Rodada do Uruguai é apresentada no Quadro 4 a seguir. 
Quadro 4 - Acordos estruturantes do sistema multilateral de comércio resultantes da Rodada do Uruguai

\begin{tabular}{|c|c|c|}
\hline Anexo & Natureza & Acordo \\
\hline \multirow{10}{*}{ Anexo 1A } & \multirow{10}{*}{ Bens } & General Agreement on Tariffs and Trade 1994 \\
\hline & & Agreement on Agriculture \\
\hline & & Agreement on the Application of Sanitary and Phytosanitary Measures \\
\hline & & Agreement on Textiles and Clothing \\
\hline & & Agreement on Technical Barriers on Trade \\
\hline & & Agreement on Trade-Related Investment Measures \\
\hline & & Agreement on Implementation of Article VI of the GATT/1994 \\
\hline & & Agreement on Implementation of Article VII of the GATT/1994 \\
\hline & & Agreement on Preshipment Inspection \\
\hline & & Agreement on Rules of Origin \\
\hline Anexo 1B & Serviços & General Agreement on Trade in Services \\
\hline Anexo 1C & $\begin{array}{l}\text { Propriedade } \\
\text { Intelectual }\end{array}$ & Agreement on Trade-Related Aspects of Intellectual Property Rights \\
\hline Anexo 2 & $\begin{array}{l}\text { Solução de } \\
\text { Controvérsias }\end{array}$ & Understanding on Rules and Procedures Governing the Settlement of Disputes \\
\hline Anexo 3 & $\begin{array}{l}\text { Política } \\
\text { Comercial }\end{array}$ & Trade Policy Review Mechanism \\
\hline \multirow{4}{*}{ Anexo 4} & \multirow{4}{*}{$\begin{array}{l}\text { Acordos } \\
\text { Plurilaterais }\end{array}$} & Agreement on Trade in Civil Aircraft \\
\hline & & Agreement on Government Procurement \\
\hline & & International Dairy Agreement \\
\hline & & International Bovine Meat Agreement \\
\hline
\end{tabular}

Fonte: Ata Final da Rodada do Uruguai e Anexos.

O GATT/1947, reproduzido e atualizado no GATT/1994, é certamente o acordo mais complexo e relevante dentro desse conjunto, pois estabelece as regras materiais ${ }^{22}$ gerais e os princípios centrais do sistema multilateral de comércio, muitos dos quais são referências para os demais acordos. Nesse sentido, os mais importantes princípios e regras do GATT, segundo destacado pela doutrina (PORTELA, 2013; PRAZERES, 2008; THORSTENSEN, 2003), são os seguintes:

a) Cláusula da nação mais favorecida (most-favoured-nation treatment MFN, na sigla em inglês): está prevista no art. I do GATT/1947 e constituiu o princípio basilar do sistema multilateral de comércio. Segundo ele, qualquer benefício (vantagem, favor, privilégio ou imunidade) tarifário ou de qualquer outra natureza de cobrança concedido por uma parte contratante a quaisquer produtos originários de outra determinada parte contratante deve ser

22 Utilizamos o termo "regras materiais" em oposição a "regras processuais". 
imediata e incondicionalmente estendido ao mesmo produto oriundo de qualquer uma das demais partes contratantes do acordo ${ }^{23}$. Trata-se, portanto, de um princípio de não discriminação entre as nações.

b) Lista de concessões: norma prevista no art. II do GATT/1947, prevê que o tratamento tarifário concedido por uma parte contratante às demais partes não pode ser menos favorável do que o previsto na lista de concessões tarifarias anexa ao acordo. Thorstensen (2003) destaca que, antes da Rodada do Uruguai, os países em desenvolvimento haviam consolidado apenas parcialmente suas listas de bens, diferentemente dos países desenvolvidos, que haviam consolidado a totalidade. Na Rodada do Uruguai, no entanto, os países em desenvolvimento viriam a realizar uma consolidação ampla.

c) Tratamento nacional: princípio previsto no art. III do GATT/1947, proíbe o tratamento discriminatório, em termos tributários e regulatórios, dos produtos importados de outras partes contratantes em relação ao produto nacional. Pode ser resumido como um princípio de não discriminação entre produto nacional e estrangeiro.

d) Transparência: princípio contemplado no art. X do GATT/1947, impõe às partes contratantes a obrigatoriedade de dar imediata publicidade a todas as normas e regulamentos referentes ao comércio internacional, incluído decisões administrativas e judiciais.

e) Eliminação das restrições quantitativas: disposta no art. XI do GATT/1947, a norma proíbe o emprego de barreiras não tarifárias, como quotas ou licenças de importação e exportação. $O$ dispositivo autoriza apenas o uso de medidas tarifárias como meios de proteção, as quais são limitadas pelo próprio acordo e tem sua aplicação mais facilmente fiscalizada. Produtos agrícolas e têxteis, no entanto, teriam regras particulares (conforme acordos específicos do Anexo $1 \mathrm{~A}$ ).

Contudo, a esses princípios gerais de liberalização comercial, cabem algumas exceções, expressamente previstas pelo próprio GATT. Existe, no art. XX do GATT,

23 Parte-contratantes era a denominação utilizada às partes signatárias do GATT/1947. No acordo constitutivo da OMC e em seus anexos, essa expressão foi substituída simplesmente por "membros". Nessa explicação sobre os princípios do GATT, optamos por utilizar os mesmos termos do acordo. 
uma previsão de exceções gerais aos dispositivos do acordo, que assegura aos países o direito de adotar medidas para proteger: a moral pública; a saúde humana, animal ou vegetal; o comércio de ouro e prata; a proteção de patentes, marcas e direitos do autor; tesouros artísticos e históricos; recursos naturais exauríveis e garantias de bens essenciais. Além disso, existem alguns outros dispositivos de exceção dispostos de maneira dispersa pelo acordo, que são:

a) Art. XII: prevê que os países possam adotar restrições aos valores e volumes importados para salvaguardar posição financeira externa ou o equilíbrio do balanço de pagamento;

b) Art. XVIII: estabelece regras especiais para os países em desenvolvimento salvaguardarem seus balanços de pagamentos;

c) Art. XIX: dispõe sobre a possibilidade de medidas emergenciais para conter, em caráter temporário, surtos de importações de determinados produtos que estejam causando ou ameaçando causar prejuízo grave aos produtores domésticos;

d) Art. XXIV: possibilita o estabelecimento de acordos regionais de comércio (uniões aduaneiras ou zonas de livre comércio), desde que os acordos cubram parte substancial dos fluxos comerciais entre os países, que os direitos ou regulamentos estabelecidos pelo acordo não sejam mais altos ou mais restritivos do que os existentes antes da formação do bloco, e que o acordo estabeleça um plano e um calendário para a constituição do bloco dentro de um prazo razoável;

e) Art. XXV.4: permite que a OMC, por $2 / 3$ de votos de seus membros, autorize um país (conceda-lhe um waiver) a suspender suas obrigações, por período determinado de tempo, em razão de circunstâncias excepcionais.

f) Parte IV: incluída no GATT em 1968, prevê princípios gerais aplicáveis ao comércio dos países em desenvolvimento, a fim de permitir o crescimento econômico desses países de acordo com as recomendações da UNCTAD.

Além do GATT, Portela (2013) considera como os principais acordos de liberalização comercial no âmbito da OMC: 
g) Acordo Geral sobre o Comércio de Serviços (General Agreement on Trade in Services - GATS): faz parte do Anexo $1 \mathrm{~B}$ da ata final da Rodada do Uruguai e destina-se a regulamentar o comércio internacional de serviços, exceto os prestados por autoridades governamentais. Compromissos firmados no acordo visam à liberalização do comércio de serviços, estabelecendo princípios como o da transparência e o da nação mais favorecida (que serviços prestados por qualquer Estado-membro não recebam tratamento menos favorável do que serviços similares prestados por outros Estados nacionais). Não obstante, o GATS não impede a celebração de acordos de liberalização de serviços bilaterais entre os países.

h) Acordo sobre Direitos de Propriedade Intelectual Relacionados ao Comércio (Agreement on Trade-Related Aspects of Intelectual Property TRIPS): constitui o Anexo $1 \mathrm{C}$ da ata final da Rodada do Uruguai. $\mathrm{O}$ acordo tem como objetivo estabelecer padrões internacionais mínimos de proteção à propriedade intelectual, incluindo direitos autorais, marcas, indicações geográficas, desenhos industriais, patentes, topografias de circuitos integrados e informações confidenciais, a fim de que a proteção contribua para a promoção da inovação tecnológica e para a transferência e a disseminação de tecnologia.

i) Acordo sobre Medidas de Investimento Relacionadas ao Comércio (Trade-Related Investment Measures - TRIMS): pertence ao Anexo $1 \mathrm{~A}$ da Ata Final da Rodada do Uruguai. Compreende um conjunto de regras que têm por objetivo regular a relação entre comércio internacional e investimentos, a fim de evitar que regulações sobre a matéria de investimentos afrontem os compromissos acordado no GATT e imponham restrições ao comércio (apenas em relação ao comércio de bens). Não obstante, as exceções à liberalização previstas no GATT também aplicam-se aos TRIMS.

j) Acordo sobre Medidas Sanitárias e Fitossanitárias (Agreement on the Application of Sanitary and Phytosanitary Measures - SPS): também pertence ao Anexo 1 da Ata Final da Rodada do Uruguai. O acordo permite que os Estados estabeleçam medidas sanitárias e fitossanitárias destinadas à proteção da vida ou da saúde humana, animal e vegetal, desde que não se configurem barreiras desnecessárias ao comércio internacional. As barreiras 
devem ser fundamentadas em evidências científicas e não podem fazer discriminação entre países onde se verifiquem as mesmas condições. Em vista disso, o acordo estabelece procedimentos de avaliação e determinação de risco e de inspeção e controle sanitário e fitossanitários.

k) Acordo sobre Barreiras Técnicas ao Comércio (Agreement on Technical Barriers on Trade - TBT): outro acordo contemplado no Anexo 1 A da Ata Final da Rodada do Uruguai, aplica-se tanto ao comércio de produtos industriais quanto agrícolas. Não se aplica, no entanto, a medidas sanitárias e fitossanitárias, que são reguladas pelo Acordo SPS, nem a compras realizadas por órgãos governamentais, que são objeto de acordo plurilateral específico no âmbito da OMC. O Acordo TBT reconhece o direto de os Estados adotarem regulamentações técnicas em conformidade com $\mathrm{O}$ acordo, a fim de não constituir barreiras desnecessárias ao comércio. Para isso, estabelece que os regulamentos técnicos não devem ser mais restritivos do que o necessário à consecução de um objetivo legítimo, o qual deve estar fundamentado no imperativo da segurança nacional, na prevenção de práticas enganosas ou na proteção da saúde ou segurança humana, da saúde ou vida animal ou vegetal ou do meio ambiente.

Esses são os principais acordos, regras e princípios que regem o sistema multilateral de comércio atualmente e condicionam acordos regionais e bilaterais de comércio e refletem sobre as instituições domésticas que regulam o comércio exterior brasileiro. Tendo em vista que este trabalho se concentra na análise das instituições que afetam o comércio de bens, o GATT torna-se o acordo mais relevante para as análises que serão realizadas a diante.

\subsubsection{As rodadas de negociação e a evolução do escopo do sistema}

As rodadas de negociação são séries de negociações multilaterais realizadas periodicamente entre os Estados participantes do sistema multilateral de comércio (chamados partes contratantes à época do GATT, atualmente denominados membros das $\mathrm{OMC}$ ) com o objetivo de avançar na liberalização do comércio internacional. 
Essa dinâmica de negociação foi prevista pelo GATT/1947 ${ }^{24}$ e vem sendo mantida pela OMC, com a diferença de que, enquanto oito rodadas foram realizadas durante os 48 anos de vigência do antigo sistema (o que representa, em média, uma rodada a cada 6 anos), a OMC tem convivido com uma única rodada desde 1995, há 11 anos. Nota-se que, com o passar dos anos, os atores se multiplicaram e o escopo das rodadas tornou-se mais abrangente e completo, dificultando a composição de interesses e a formação de consenso entre os países.

They are often lengthy - the Uruguay Round took seven and a half years - but trade rounds can have an advantage. They offer a package approach to trade negotiations that can sometimes be more fruitful than negotiations on a single issue. (WTO, 2015, p. 17)

O Quadro 5 apresenta as oito rodadas do GATT/1947 e as temáticas e o número de participantes contemplados em cada uma delas. Verifica-se que as cinco primeiras rodadas concentraram-se exclusivamente na liberalização tarifária, e o número de partes envolvidas não passou de 38. Sobre esse assunto, Luz (2008, p. 206) explica que "o eixo principal do GATT assim se apresenta: tarificação de barreiras, fixando-se alíquotas máximas de imposto de importação nas listas anexadas ao GATT, para depois reduzi-las periodicamente nas rodadas de negociação"; por isso, as primeiras rodas objetivaram apenas a redução das tarifas consolidadas no GATT, visando, se possível, sua eliminação.

\footnotetext{
24 GATT/1947, art. XXVIII bis, 1: The contracting parties recognize that customs duties often constitute serious obstacles to trade; thus negotiations on a reciprocal and mutually advantageous basis, directed to the substantial reduction of the general level of tariffs and other charges on imports and exports and in particular to the reduction of such high tariffs as discourage the importation even of minimum quantities, and conducted with due regard to the objectives of this Agreement and the varying needs of individual contracting parties, are of great importance to the expansion of international trade. The CONTRACTING PARTIES may therefore sponsor such negotiations from time to time.
} 
Quadro 5 - Rodadas de negociação no âmbito do GATT/1947

\begin{tabular}{|c|c|c|c|c|}
\hline Número & Ano & $\begin{array}{l}\text { Local/Nome da } \\
\text { Rodada }\end{array}$ & Assuntos Cobertos & Países \\
\hline 1 & 1947 & Genebra & Tarifas & 23 \\
\hline 2 & 1949 & Annecy & Tarifas & 13 \\
\hline 3 & 1951 & Torquay & Tarifas & 38 \\
\hline 4 & 1956 & Genebra & Tarifas & 26 \\
\hline 5 & $1960-1961$ & $\begin{array}{c}\text { Genebra / Rodada } \\
\text { Dillon }\end{array}$ & Tarifas & 26 \\
\hline 6 & $1964-1967$ & $\begin{array}{l}\text { Genebra / Rodada } \\
\text { Kennedy }\end{array}$ & $\begin{array}{l}\text { Tarifas e medidas } \\
\text { antidumping }\end{array}$ & 62 \\
\hline 7 & $1973-1979$ & $\begin{array}{c}\text { Genebra / Rodada } \\
\text { Tokyo }\end{array}$ & $\begin{array}{c}\text { Tarifas, medidas não } \\
\text { tarifárias e cláusula de } \\
\text { habilitação }\end{array}$ & 102 \\
\hline 8 & 1986-1994 & $\begin{array}{c}\text { Genebra / Rodada } \\
\text { do Uruguai }\end{array}$ & $\begin{array}{l}\text { Tarifas, medidas não } \\
\text { tarifárias, serviços, } \\
\text { propriedade intelectual, } \\
\text { solução de controvérsias, } \\
\text { têxteis, agricultura, criação } \\
\text { da OMC, entre outros }\end{array}$ & 123 \\
\hline
\end{tabular}

Fonte: Organização Mundial do Comércio e Secretaria de Comércio Exterior do Ministério do Desenvolvimento, Indústria e Comércio Exterior

A Rodada Kennedy, ocorrida entre 1964 e 1967, foi a primeira a incluir um tema além de redução tarifária, e resultou na celebração do Acordo Antidumping, o qual forneceu o detalhamento necessário ao art. VI do $\mathrm{GATT}^{25}$. Apesar de o escopo das negociações ter-se restringido a esses dois temas, foi durante essa rodada, em 1965, que se incluiu ao GATT/1947 um capítulo exclusivamente dedicado ao tema de comércio e desenvolvimento, a Parte IV. Esse avanço, destaca Oliveira (2007), ocorreu no mesmo momento em que os países em desenvolvimento ganhavam um novo foro de debate no âmbito das Nações Unidas, a UNCTAD (United Nations Conference on Trade

25 Dispõe o trecho inicial do art. VI do GATT: The contracting parties recognize that dumping, by which products of one country are introduced into the commerce of another country at less than the normal value of the products, is to be condemned if it causes or threatens material injury to an established industry in the territory of a contracting party or materially retards the establishment of a domestic industry. 
and Development), e refletia sua insatisfação com a dinâmica de liberalização que vinha sendo empreendida no sistema multilateral de comércio $^{26}$.

Em seguida, a Rodada Tóquio (1973-1979) concentrou-se no ataque às barreiras não tarifárias, cuja multiplicação havia sido o meio protecionista encontrado pelos países diante da proibição das quotas e da limitação das tarifarias nas rodadas anteriores (LUZ, 2008). À época, apenas um número pequeno dos membros do GATT aderiu aos acordos relativos a barreiras não tarifarias, informalmente chamados de "códigos". Apesar disso, muitos desses códigos seriam revisados e transformados em acordos multilaterais durante a Rodada do Uruguai, impondo-se sua aceitação a todos os membros da OMC. Apenas 4 acordos permaneceram como plurilaterais: sobre compras públicas, aviação civil, carne bovina e lácteos, sendo que os dois últimos foram extintos pela OMC em 1997.

Outro importante avanço da Rodada Tóquio foi a adoção da chamada cláusula de habilitação, que permitiu um tratamento especial aos países em desenvolvimento, por meio de um Sistema Geral de Preferências (SGP) ${ }^{27}$. Por esse sistema, países desenvolvidos foram autorizados a conceder reduções tarifárias diferenciadas e não recíprocas a países em desenvolvimento, sem necessidade de estender a concessão aos demais membros da OMC (excepcionando o princípio da nação mais favorecida). Mas, diferentemente do esperado, os países em desenvolvimento não lograram estabelecer o sistema em bases permanentes (OLIVEIRA, 2007), e ficou estabelecido que o SGP seria temporário, sujeito a renovações periódicas e à definição das mercadorias elegíveis pelos países outorgantes.

A oitava rodada do GATT teve início apenas 7 anos após o encerramento da anterior, e foi lançada por ocasião da reunião ministerial ocorrida em Punta del Este. Desde a reunião ministerial de Genebra, em 1982, os EUA vinham empreendendo esforços para emplacar a discussão de novos temas no âmbito do GATT, ao que resistiam a União Europeia e os países em desenvolvimento, cujo foco permanecia em agricultura (OLIVEIRA, 2007). Finalmente no Uruguai, em 1986, se obteve o consenso necessário para o lançamento da nova rodada, que incluiria tanto os temas pendentes

\footnotetext{
26 Segundo constatou relatório técnico encomendado pelas partes contratantes do GATT (o chamado Haberler Committee Report), de 1958, o baixo dinamismo das exportações dos países em desenvolvimento devia-se às políticas comerciais adotadas pelos países desenvolvidos (OLIVEIRA, 2007, p. 233), o que justificaria a adoção, no sistema multilateral de comércio, de políticas mais flexíveis em relação a esse primeiro grupo de países.

27 O SGP foi idealizado pela UNCTAD em 1968 e autorizado pelo GATT em 1971.
} 
(como agricultura, têxteis e subsídios) quanto os novos (serviços, propriedade intelectual e investimentos). O mandato da Rodada do Uruguai foi o mais ambicioso que se estabelecera até então, e todos os dispositivos do GATT estavam abertos a revisão.

Inicialmente, a Rodada estava prevista para durar quatro anos, mas a complexidade das negociações foi tanta que o acordo final acabou custando quase o dobro do tempo. Alguns temas chegaram a ser acordados na reunião ministerial de Montreal, em 1988, quando se acreditava estar na metade do caminho para o fim da Rodada. No entanto, na reunião de 1990, em Bruxelas, os países chegaram a um impasse sobre agricultura e as negociações entraram na sua fase mais difícil. $\mathrm{Na}$ sequência, outros temas se agregariam à lista dos impasses, como serviços, acesso a mercados, regras de antidumping e, finalmente, a criação de uma nova organização.

Em 1992, EUA e União Europeia conseguiram conciliar suas divergências na área agrícola, por meio do que ficou conhecido como Acordo Blair House e, no ano seguinte, EUA, UE, Japão e Canadá obtiveram avanços na negociação de tarifas e acesso a mercados. Por fim, em dezembro de 1993, conseguiu-se chegar a um consenso geral sobre os temas em negociação, e em abril de 1994 foi assinado o acordo final, em Marraqueche.

The delay had some merits. It allowed some negotiations to progress further than would have been possible in 1990: for example some aspects of services and intellectual property, and the creation of the WTO itself. But the task had been immense, and negotiation-fatigue was felt in trade bureaucracies around the world. The difficulty of reaching agreement on a complete package containing almost the entire range of current trade issues led some to conclude that a negotiation on this scale would never again be possible. (WTO, 2015, p. 19)

Galvão, Abreu e Pimentel (2015) consideram que a nova organização conseguiu superar diversas limitações que maculavam o GATT, como o arranjo institucional fragmentado decorrente dos inúmeros acordos plurilaterais, a exclusão dos temas agrícolas (de grande interesse para o Brasil) e o falho mecanismo de solução de controvérsias. A OMC, em oposição a isso, foi capaz de estabelecer um sistema efetivamente multilateral de comércio, com a ampliação do número de membros, regras universais, expansão da cobertura normativa - com a importante inclusão de temas agrícolas, serviços e propriedade intelectual - e aperfeiçoamento do sistema de solução de controvérsias. Apesar disso, os autores consideram que os resultados da Rodada do Uruguai geraram um déficit em relação aos países em desenvolvimento, tendo em vista 
"estabelecer obrigações ambiciosas em novas áreas de interesse do mundo desenvolvido (propriedade intelectual e serviços), reduzir a latitude para política industrial nos PEDs (...), oferecendo, em contrapartida, disciplinas claramente insuficientes em agricultura" (GALVÃO; ABREU; PIMENTEL, 2015, p. 6).

Uma primeira tentativa de lançamento de nova rodada foi feita durante a III Conferência Ministerial da OMC, 1999, em Seatle, a qual seria denominada "Rodada do Milênio". A tentativa, contudo, acabou fracassada, em razão das dificuldades de composição entre Estados Unidos e União Europeia sobre questões agrícolas e em meio ao clima de pressão da sociedade civil sobre o encontro. Finalmente, na IV Conferência Ministerial, ocorrida em Doha, em 2001, apesar da descrença que as dificultosas negociações da Rodada do Uruguai e a Conferência de Seatle provocaram, os países acordaram lançar uma nova rodada de negociações. A denominada Rodada Doha, também conhecida como Rodada do Desenvolvimento, elegeu temas próprios, mas também procurou trabalhar na implementação dos acordos firmados na Rodada do Uruguai, estabelecendo cronogramas de implementação.

O programa de trabalho da rodada, apresentado na Declaração Final da Conferência Ministerial de Doha, e estabeleceu entre os temas principais da Rodada:
a) Agricultura;
b) Serviços;
c) Acesso a mercados para produtos agrícolas;
d) Aspectos dos direitos de propriedade intelectual relacionados ao comércio;
e) Relação entre comércio e investimentos;
f) Relação entre comércio e política de concorrência;
g) Transparência na contratação pública;
h) Facilitação de comércio;
i) Comércio e meio ambiente;
j) Comércio eletrônico.

Para reger o funcionamento das novas negociações, adotou-se o princípio do single undertakin - "nada está acordado até tudo estar acordado" -, que impôs a obrigatoriedade de que todos os temas sejam acordados em um pacote único de 
compromissos. As negociações tornaram-se tão dificultosas que a Rodada Doha, prevista para durar até 2005 , vem-se estendendo até os dias atuais.

Diante disso, a partir de 2009 , os países desenvolvidos passaram a defender o que chamaram de "colheita antecipada", que seria a busca de resultados antecipados (antes do fim da rodada) para temas específicos, como serviços e facilitação de comércio. As negociações de serviços acabaram sendo lançadas em 2012, mas em âmbito plurilateral, reunindo cerca de 50 países na negociação do TiSA (Trade in Services Agreement). O tema de facilitação de comércio, diferentemente, viria a ser objeto de um acordo multilateral que resultou da Conferência Ministerial de Bali, em 2013, o qual foi aprovado pelo Conselho Geral da OMC em novembro de 2014 e tornouse o primeiro acordo multilateral da Organização. Na Conferência Ministerial seguinte, ocorrida em Nairobi, em 2015, foi aprovado um pacote compreendendo seis Decisões Ministeriais sobre agricultura, algodão e questões referentes a países de menor desenvolvimento relativo.

Até o momento, contudo, não se conseguiu chegar a um acordo abrangente, compreendendo todos os temas que compõem o mandato de Doha. Apesar dos pacotes sobre temas pontuais que foram lançados nas duas últimas Conferências Ministeriais - Bali e Nairobi -, os países em desenvolvimento defendem a manutenção do mandato integral e pressionam por negociações mais ambiciosas nos temas agrícolas. Ao mesmo tempo, os temas de interesse dos países desenvolvidos, sobretudo o acesso a mercados para produtos industrializados, ficam na dependência do equacionamento no âmbito da agricultura, e o futuro da Rodada segue incerto.

\subsection{O comércio internacional e o regionalismo}

\subsubsection{A relação entre regionalismo e sistema multilateral}

O histórico de arranjos comerciais preferenciais, bilaterais ou regionais, é anterior à constituição do sistema multilateral de comércio. Durante a década de 1940, esse tipo de acordo já era tão difundido que seu reconhecimento pelo GATT/1947 impôs-se como condição necessária para a adesão de diversos países ao acordo (PRAZERES, 2008, p. 260). Portanto, os acordos regionais de comércio são mecanismos de integração previstos e autorizados dentro do sistema multilateral de comércio. 
O GATT, em seu art. XXIV, previu o estabelecimento de acordos regionais de comércio como uma exceção ao princípio da nação mais favorecida, considerando que uniões aduaneiras e áreas de livre comércio sejam estabelecidos com a finalidade de facilitar o comércio entre as partes, e não de impor barreiras contra o comércio de terceiros países ${ }^{28}$. Nesse sentido, estabeleceu alguns critérios que devem ser obedecidos pelos acordos regionais, conforme consta no item 5 do art. XXIV:

5. Accordingly, the provisions of this Agreement shall not prevent, as between the territories of contracting parties, the formation of a customs union or of a free-trade area or the adoption of an interim agreement necessary for the formation of a customs union or of a free-trade area; Provided that:

(a) with respect to a customs union, or an interim agreement leading to a formation of a customs union, the duties and other regulations of commerce imposed at the institution of any such union or interim agreement in respect of trade with contracting parties not parties to such union or agreement shall not on the whole be higher or more restrictive than the general incidence of the duties and regulations of commerce applicable in the constituent territories prior to the formation of such union or the adoption of such interim agreement, as the case may be;

(b) with respect to a free-trade area, or an interim agreement leading to the formation of a free-trade area, the duties and other regulations of commerce maintained in each if the constituent territories and applicable at the formation of such free-trade area or the adoption of such interim agreement to the trade of contracting parties not included in such area or not parties to such agreement shall not be higher or more restrictive than the corresponding duties and other regulations of commerce existing in the same constituent territories prior to the formation of the free-trade area, or interim agreement as the case may be; and

(c) any interim agreement referred to in sub-paragraphs (a) and (b) shall include a plan and schedule for the formation of such a customs union or of such a free-trade area within a reasonable length of time.

Conforme se verifica no texto do artigo, as zonas de livre comércio e as uniões aduaneiras não podem estabelecer direitos aduaneiros ou outros regulamentos comerciais mais restritivos em relação a terceiras partes do que antes da formação do bloco. Após a constituição do bloco, caso sejam fixadas tarifas em relação a terceiros

\footnotetext{
${ }^{28}$ A diferença entre área de livre comércio e união aduaneira é que, no primeiro caso, os países integrantes do bloco eliminam as barreiras tarifarias e não tarifárias entre si, mas mantém políticas tarifárias autônomas em relação a terceiros países; enquanto no segundo caso, além da eliminação interna das barreiras, os países adotam uma política aduaneira comum em relação a terceiros, por meio da adoção de uma tarifa externa comum.
} 
mais altas do que as consolidadas na OMC, é necessária uma renegociação com os demais membros da OMC a fim de garantir a compensação necessária (art. XXIV.6). Além disso, também é exigido que uniões aduaneiras e áreas de livre comércio eliminem tarifas e restrições ao comércio em relação a parte substancial do comércio entre os países (art. XXIV.8). Em caso de acordos intermediários, destinados à conformação futura de uma união aduaneira ou área de livre comércio, é necessária a previsão de um cronograma de liberalização, a ser concretizado dentro de um prazo razoável (art. XXIV.5.c).

Todos os acordos regionais devem ser notificados à $\mathrm{OMC}$ e submetidos à apreciação do Comitê sobre Acordos Regionais de Comércio, que avalia o cumprimento dos requisitos estabelecidos pelo acordo. Cabe destacar que a cláusula de habilitação flexibiliza estes requisitos para o caso dos países em desenvolvimento, tornando mais fácil a conformação de acordos preferenciais entre países dessa categoria. Para o comércio de serviços, a autorização ao tratamento mais favorecido em acordos regionais de comércio está disposta no art. $\mathrm{V}$ do GATS.

Com relação aos arranjos preferenciais previamente existentes ao GATT/1947, como ocorria entre o Reino Unido e os territórios do Império Britânico, o art. I do GATT excetuou esses acordos da regra da nação mais favorecida, mas proibiu o aumento das margens de preferência estabelecidas, assim como a criação de novos acordos preferenciais de cobertura limitada.

Sobre a questão dos acordos de cobertura limitada, Prazeres (2008, p. 262) afirma:

Boa parcela da literatura admite que inexistem motivos econômicos claros para autorizar um arranjo regional que discrimine $100 \%$ do comércio interno (ou substancialmente todo o comércio interno) e ao mesmo tempo proibir os que liberalizem parte menos substantiva do comércio interno.

Não obstante, foi dessa forma que o GATT e a OMC optaram por acolher os acordos regionais de comércio e é sob essas regras que o regionalismo convive com o sistema multilateral de comércio. 
3.2.2 A evolução dos acordos regionais de comércio na América do Sul: da ALAC ao MERCOSUL

Os processos de integração comercial da América Latina no século XX tiveram início na década de 1950 e estão associados ao desenvolvimento do pensamento da Comissão Econômica para América Latina e Caribe (CEPAL). A CEPAL é uma das cinco comissões regionais das Nações Unidas, ligada ao seu Conselho Econômico e Social (ECOSOC), que foi criada em 1948 com o objetivo de incentivar as relações econômicas entre os países da região e coordenar ações nesse sentido, de modo a contribuir para o desenvolvimento econômico da América Latina e do Caribe.

Estudos desenvolvidos pela Comissão entre as décadas de 1940 e de 1950 diagnosticavam o problema do desenvolvimento latino-americano como decorrência da deterioração dos termos de troca dos produtos exportados pela região, o que, por sua vez, refletia as características das pautas exportadoras dos países latino-americanos, majoritariamente concentradas em produtos básicos de pouco valor agregado. Como estratégia de superação dessa condição, a CEPAL propunha a adoção de políticas de industrialização substitutiva de importações pelos países, a fim de reduzir os problemas de balanço de pagamentos decorrentes das importações e melhorar a diversificação e os termos de troca da pauta exportadora. Adicionalmente, os estudos alertavam para a importância da expansão do mercado consumidor para os produtos manufaturados da região, sugerindo que fossem concedidas condições especiais de importação pelos países desenvolvidos (o que, de fato, se concretizou com o SGP) e incentivando a formação de um mercado ampliado por meio da integração comercial entre os países da região $0^{29}$.

A partir dessa visão, Argentina, Brasil, Chile e Uruguai iniciaram conversas, em 1959, com vistas à formação de uma área de livre comércio (FERREIRA JUNIOR, 2003, p. 14). O processo de aproximação acabou levando, em 1960, a conformação da Associação Latino-Americana de Livre Comércio (ALALC), estabelecida pelo Tratado de Montevidéu. Além dos quatros países já mencionados, compunham a ALALC México, Peru, Paraguai, Bolívia, Colômbia, Equador e Venezuela, o que representava a maior parte da economia latino-americana.

A respeito da ALALC, destacou Furtado (2005, pp. 361-362):

29 Para mais informações sobre o pensamento cepalino, vide Bernal-Meza (2005). Sobre a influência das teses da CEPAL no processo de integração regional da América Latina, vide Furtado (2007), cap. 21. 
O Tratado de Montevidéu está duplamente concebido dentro do espírito do GATT: pelo seu objetivo, que é liberalizar o intercâmbio na área, e não propriamente formar uma união aduaneira, e pelos seus processos operacionais, que consistem em negociações bilaterais produto a produto, excluindo os esquemas de liberalização automática e linear que caracterizaram o desenvolvimento da Associação de Livre Comércio Europeia e a Comunidade Econômica Europeia. Essa consideração é importante, pois indica que o referido tratado constituiu muito mais uma resposta a problemas limitados surgidos em torno do comércio dos países meridionais do que propriamente uma abertura no sentido de estruturar em bases novas as relações econômicas entre os países da região.

Cabe também destacar que, reproduzindo os princípios aplicáveis a países menos desenvolvidos no sistema multilateral do GATT, a ALALC também previu mecanismos de tratamento diferenciados para as economias menores e relativamente mais atrasadas (grupo em que foram classificados Bolívia, Equador e Paraguai), como concessões de comércio não recíproca, medidas de proteção à indústria e convênios de assistência técnica e financeira (FERREIRA JUNIOR, 2003, p. 17).

Furtado (2005, p. 365) avalia que os resultados da ALALC foram modestos, especialmente considerando que, a partir de 1965, a evolução do comércio entre os países do bloco tornou-se irregular. Ademais, persistia o desequilíbrio das exportações intrazona em favor dos maiores países do bloco, especialmente Argentina e Brasil, que respondiam por mais de $60 \%$ do volume exportado (FURTADO, 2005, p. 364). Não por outro motivo, passou-se a buscar um caminho alternativo para a integração econômica e comercial da região, o que levou a um movimento de integração sub-regional pelos países andinos.

O movimento foi liderado pelo Chile, país da região cujas dimensões do mercado interno mais afetavam seu processo de industrialização e sua capacidade de crescimento (FURTADO, 2005, p. 367). Embora em menor proporção, a mesma dificuldade era enfrentada por todos os países médios da região, cujas economias não eram capazes de competir com os grandes países do bloco (Argentina, Brasil e México). Em resposta, em 1969, Chile, Peru, Colômbia, Equador e Bolívia estabeleceram o Pacto Andino, constituído por meio do Acordo de Cartagena. A Venezuela, embora tenha feito parte do processo de constituição do bloco desde o início, aderiu formalmente ao Pacto apenas em 1973. O objetivo do grupo era estabelecer um passo intermediário para a integração total da América Latina, mas o Pacto acabou adquirindo um perfil próprio: 
A estratégia que está na base de estruturação do Grupo Andino é distinta da que inspirou a criação da ALALC. Tem-se em vista uma liberalização automática e irreversível do comércio, particularmente dos produtos que não se produzem atualmente em nenhum dos países da sub região, simultaneamente com a uniformização da tarifa face a terceiros países, isto é, objetiva-se a criação de uma união aduaneira. (FURTADO, 2005, p. 367).

A estratégia de integração passou por mudanças ao longo do tempo, tendo se iniciado por políticas de industrialização por substituição de importações, na década de 1970, e passando para um modelo mais aberto em fins dos anos de 1980. Em 1993, foram eliminadas as tarifas internas e se constituiu uma zona de livre comércio. Em 1997, foram promovidas algumas reformas institucionais no Acordo de Cartagena e o Pacto Andino passou a ser denominado de Comunidade Andina, nome que vem sendo mantido desde então ${ }^{30}$. Cabe destacar que o Chile, por opção do governo Pinochet, deixou o bloco em 1976, alegando incompatibilidades econômicas entre o bloco e os novos objetivos de política econômica do país. Em 2006, foi a vez da Venezuela deixar a Comunidade Andina, como protesto aos acordos de livre comércio assinados por Colômbia e Peru com os Estados Unidos.

Ao mesmo tempo em que o bloco andino se estruturava, na década de 1970, a ALALC passava por um período de letargia, com a paralisação das negociações multilaterais e o agravamento da situação econômica dos países - para o que contribuíram os choques do petróleo de 1973 e 1979 e o crescente endividamento externo da região (FERREIRA JUNIOR, 2003, p. 19). Apesar disso, uma nova tentativa de integração seria levada a cabo na década de 1980, a partir da criação da Associação Latino-Americana de Integração (ALADI).

A ALADI foi estabelecida pelo Tratado de Montevidéu, em 1980, com o objetivo de dar continuidade e aprofundar o processo de integração iniciado com a ALALC. A intenção da ALADI era promover a implantação gradual de um mercado comum latinoamericano. O bloco é composto por 13 países, que são Argentina, Bolívia, Brasil, Chile, Colômbia, Cuba, Equador, México, Panamá, Paraguai, Peru, Uruguai e Venezuela, que são classificados em 3 categorias de desenvolvimento de acordo com características econômicas e estruturais: países de menor desenvolvimento relativo - PMDER (Bolívia, Equador e Paraguai); países de desenvolvimento intermediário - PDI (Chile, Colômbia,

\footnotetext{
30 Para mais informações sobre história e características do Pacto Andino, vide informações disponíveis no sítio eletrônico < http://www.comunidadandina.org/>.
} 
Peru, Uruguai, Venezuela, Cuba e Panamá) e demais países (Argentina, Brasil e México).

$\mathrm{O}$ art. $3^{\circ}$ do Tratado prevê que a integração latino-americana deve ser orientada pelos seguintes princípios:
a) pluralismo político e econômico;
b) convergência progressiva das ações para criação de um mercado comum latino-americano;
c) flexibilidade;
d) tratamentos diferenciados, de acordo com o nível de desenvolvimento do país membro;
e) multiplicidade das formas de concertação;
f) multiplicidade dos instrumentos comerciais.

Para consecução desses objetivos, 0 art. $4^{\circ}$ do Tratado dispõe sobre a possibilidade de utilização de três diferentes mecanismos de integração, que são a preferência tarifária regional, os acordos de alcance regional (dos quais participam todos os membros) e os acordos de alcance parcial (dos quais participam apenas alguns dos membros). Estes últimos, por sua vez, são geralmente de 4 modalidades (art. $8^{\circ}$ ): comerciais, de complementação econômica, agropecuários e de promoção de comércio, mas podem também versar sobre cooperação em matérias como ciência e tecnologia, promoção do turismo e preservação do meio ambiente (art. 14). Exige-se, contudo, que os tratados de alcance parcial estejam abertos à adesão dos demais países membros da ALADI.

Essa possibilidade de acordos de alcance parcial entre os membros da ALADI é considerada um grande avanço em relação à dinâmica de relacionamento dos países no âmbito da antiga ALALC. Esta era regida pelo princípio da nação mais favorecida, e qualquer concessão comercial feira por um dos membros a algum país teria de ser automaticamente estendida a todos os demais membros da ALALC. A flexibilização trazida pela ALADI em relação a esse aspecto, permitindo acordo comerciais entre dois ou mais países-membros, é certamente um dos fatores responsáveis pela sua persistência até os dias atuais. Outro aspecto importante da ALADI é que seu tratado constitutivo, no âmbito da OMC, está notificado ao amparo da cláusula de habilitação, o que permite que as preferências tarifárias e as medidas de liberalização não tarifárias 
adotadas entre seus membros não precisem ser estendidas aos demais membros da OMC.

De acordo com dados do Ministério das Relações Exteriores, atualmente, cerca de $70 \%$ do comércio entre os países da ALADI é totalmente desgravado, sendo que, no Brasil, o valor do comércio com $100 \%$ de preferência tarifária é de aproximadamente $75 \%$ das exportações e $90 \%$ das importações. A expectativa é de que o comércio no âmbito da ALADI se torne $100 \%$ liberalizado em $2019^{31}$.

Com a previsão de acordos de alcance parcial, a ALADI deu espaço para a realização de iniciativas de integração sub-regionais, que foi o que permitiu a criação do Mercado Comum do Sul (MERCOSUL).

O processo de integração que culminou com a criação do MERCOSUL teve início em meados da década de 80, a partir do estreitamento dos laços comerciais entre Brasil e Argentina. Não obstante as divergências e a competitividade que costumavam caracterizar as relações entre os dois países, o estreitamento foi impulsionado pelas dificuldades econômicas comuns com que ambos se deparavam, marcadas pela altíssima dívida externa contraída pelos governos militares, bem como pelas políticas protecionistas impostas pelas nações mais desenvolvidas da Europa e da América do Norte.

Inicialmente, em 1985, Brasil e Argentina firmaram um acordo de integração conhecido por "Declaração de Iguaçu". No ano seguinte, instituíram o Programa de Integração e Cooperação Econômica - PICE, através da assinatura da Ata para Integração Argentino-Brasileira. Nessa ata, já foi possível se verificar a presença de alguns dos princípios que norteariam o Tratado de Assunção, como flexibilidade, gradualismo, simetria (para promover políticas específicas relacionadas à competitividade setorial) e equilíbrio dinâmico (para proporcionar uma integração setorial uniforme).

Em 1988, foi assinado o Tratado de Integração, Cooperação e Desenvolvimento Argentina - Brasil, juntamente com outros 24 Protocolos versando a respeito de diversos assuntos de interesse dos dois países. Esse tratado teve como objetivo estruturar a formação de um espaço econômico comum, estabelecendo, para isso, um período de 10 anos. Em julho de 1990, foi firmada a Ata de Buenos Aires, fixando o

\footnotetext{
31 Vide informações disponíveis no sítio eletrônico do MRE:

$<$ http://www.itamaraty.gov.br/pt-BR/politica-externa/integracao-regional/690-associacao-latinoamericana-de-integracao-aladi>.
} 
prazo de 5 anos para a entrada em vigência de um mercado comum entre Brasil e Argentina e, em dezembro do mesmo ano, os protocolos assinados em 1988 foram consolidados em um Acordo de Complementação Econômica - ACE 14, que consistiu em um acordo de alcance parcial firmado no âmbito da ALADI.

Em 26 de março de 1991, foi finalmente assinado por Argentina, Brasil, Paraguai e Uruguai o Tratado de Assunção, o qual estabeleceu a criação e os contornos do Mercado Comum do Sul - MERCOSUL. No âmbito da ALADI, o acordo que normatiza as operações no âmbito do MERCOSUL é o ACE 18, de 21 de novembro de 1991. A partir de então, teve início a chamada fase de transição do MERCOSUL, entendida como o período compreendido entre 1991 e 1994, durante o qual foi desenvolvido um Programa de Liberalização Comercial. Tal programa tratou, sobretudo, de reduções tributárias progressivas e negociações de políticas comerciais comuns. Na sequência, o protocolo foi aditado por Protocolos Adicionais, a exemplo do Protocolo de Brasília (1993), tratando sobre seu sistema de solução de controvérsias, e o Protocolo de Ouro Preto (1996), o qual conferiu ao MERCOSUL personalidade jurídica de direito internacional e permitiu a sua relação com outros países, blocos econômicos e organismos internacionais.

Em maio de 2006, a Venezuela, que já havia assinado um acordo de intenção com o bloco em dezembro do ano anterior, passou a fazer parte como membro pleno do MERCOSUL por meio da assinatura de um tratado de adesão, tomando parte em todos os compromissos e acordos firmados entre os membros originais do bloco. A Venezuela concluiu seu processo de adesão em 2012, mesmo ano em que a Bolívia assinou seu Protocolo de Adesão ao MERCOSUL, tendo sido oficializada como membro pleno da reunião da CMC do primeiro semestre de 2015.

Além disso, o MERCOSUL conta ainda com os seguintes membros associados:
a) o Chile, desde 1996;
b) o Peru, desde 2003;
c) a Colômbia, desde 2004;
d) o Equador, desde 2004;
e) Guiana, desde 2013;
f) Suriname, desde 2013. 
Verifica-se, portanto, que todos os países sul-americanos estão de alguma forma vinculados ao MERCOSUL, seja como membro pleno, seja como Estado associado. Essa constatação é importante, pois demonstra a importância atribuída a esse processo de integração pelos países da região. Isso porque, muito mais do que ser uma união aduaneira, o MERCOSUL proporcionou a aproximação política e social entre os países, promovendo iniciativas de cooperação em diversas agendas. Neste trabalho, contudo, o foco da análise recairá apenas sobre a dimensão comercial do bloco.

3.2.3 As instâncias deliberativas do MERCOSUL e a criação das normativas comerciais pelo bloco

O Protocolo de Ouro Preto, firmado na cidade de Ouro Preto em 17 de dezembro de 1994, conferiu personalidade jurídica de direito internacional público ao bloco e estabeleceu o cerne de sua estrutura institucional. Enquanto mantém a personalidade jurídica para atuar com atores externos, internamente, o bloco se caracteriza como uma organização intergovernamental, em que cada Estado mantém sua individualidade e autonomia e cujas decisões são tomadas por meio de consenso entre os países. Os três órgãos intergovernamentais com capacidade decisória do MERCOSUL são o Conselho do Mercado Comum (CMC), o Grupo Mercado Comum (GMC) e a Comissão de Comércio do MERCOSUL (CCM).

O CMC é o órgão superior do bloco, foi criado pelo tratado constitutivo do MERCOSUL - o Tratado de Assunção - e tem competência para conduzir a política do processo de integração e tomada de decisões, a fim de assegurar o cumprimento dos objetivos do tratado e permitir a conformação do mercado comum. Ele é formado pelos Ministros das Relações Exteriores e da Economia dos Estados-membros, reúne-se ao menos uma vez por semestre e delibera por meio de Decisões, que são adotadas por consenso (que exige a presença de todos os países) e tornam-se obrigatórias para todos os Estados-membros. A presidência pro tempore da CMC é exercida alternadamente por cada um dos membros, em ordem alfabética, a cada seis meses.

A principal Decisão do CMC em termos de normatização da disciplina comercial no bloco é a Decisão 32/00, proferida na XVIII CMC, em 29 de junho de 2000. A Decisão 32/00 dispõe que as partes só poderão negociar acordos comerciais com 
terceiros países de forma conjunta, em bloco. Com isso, os membros do MERCOSUL ficaram impedidos de outorgar preferências tarifárias a qualquer país extra zona de maneira individual, sem o consentimento dos demais membros. O objetivo dessa normativa é manter a política aduaneira comum entre os países, de modo a preservar a união aduaneira. Recentemente, a Decisão 32/00 vem sendo considerada uns dos fatores responsáveis pelo travamento das negociações extra regionais dos países do bloco (inclusive com a União Europeia), fazendo com que o Uruguai venha advogando, desde 2015, uma flexibilização dessa normativa.

O GMC, também criado pelo Tratado de Assunção, é o principal órgão executivo do MERCOSUL e está subordinado ao CMC. Entre as atribuições do GMC, estão o zelo pela aplicação dos tratados do bloco, a proposição de projetos de Decisão ao CMC, a fixação de programas de trabalho, a adoção de resoluções em matérias financeira e orçamentária e a criação e extinção de órgãos especializados, como os subgrupos de trabalho (que podem ser permanentes ou ad hoc). O grupo é composto por delegações de quatro membros titulares e quatro alternos de cada Estado, dos quais devem fazer parte os Ministérios das Relações Exteriores, os Bancos Centrais e os Ministérios da Economia de cada país. As deliberações do GMC são denominadas Resoluções, as quais necessitam ser aprovadas por consenso e serão obrigatórias para todos os Estados, assim como as Decisões.

Atualmente, existem 17 subgrupos de trabalho permanentes que se reportam ao GMC, correspondentes aos seguintes temas:

a) SGT n. 1: Comunicações (coordenador nacional no Brasil: ANATEL);

b) SGT $n^{\circ}$. 2: Aspectos Institucionais (coordenador nacional no Brasil: MRE);

c) SGT $n^{\circ}$. 3: Regulamentos Técnicos e Avaliação de Conformidade (coordenador nacional no Brasil: INMETRO);

d) SGT no. 4: Assuntos Financeiros (coordenador nacional no Brasil: BCB);

e) SGT $n^{\circ}$. 5: Transportes (coordenador nacional no Brasil: ANTT);

f) SGT $n^{\circ}$. 6: Meio Ambiente (coordenador nacional no Brasil: MMA);

g) SGT n. 7: Indústria (coordenador nacional no Brasil: MDIC);

h) SGT n'. 8: Agricultura (coordenador nacional no Brasil: MAPA);

i) SGT $n^{\circ}$. 9: Energia (coordenador nacional no Brasil: MME);

j) SGT $n^{\circ}$. 10: Assuntos Trabalhistas, Emprego e Seguridade Social (coordenador nacional no Brasil: MTE); 
k) SGT n. 11: Saúde (coordenador nacional no Brasil: MS);

l) SGT n ${ }^{\circ}$. 12: Investimentos (coordenador nacional no Brasil: MF);

m) SGT n'. 13: Comércio Eletrônicos (coordenador nacional no Brasil: MCT);

n) SGT n'. 14: Integração Produtiva (coordenador nacional no Brasil: MDIC);

o) SGT n ${ }^{0}$. 15: Mineração e Geologia (coordenador nacional no Brasil: MME);

p) SGT n ${ }^{\circ}$. 16: Contratações Públicas (coordenador nacional no Brasil: MPOG);

q) SGT n ${ }^{\circ}$. 17: Serviços (coordenador nacional no Brasil: MRE).

Cada subgrupo de trabalho está a cargo de um coordenador nacional (conforme indicado entre parênteses acima) e, no Brasil, a maior parte das coordenações está sob a responsabilidade de ministérios técnicos, embora o Ministério das Relações Exteriores seja o coordenador de alguns deles. Especificamente quanto ao Ministério do Desenvolvimento, Indústria e Comércio Exterior estão relacionados o SGT 7 (Indústria), e o SGT 14 (Integração Produtiva), mas seus objetivos estão mais associados a política industrial do que a questões de comércio exterior. A despeito disso, são subgrupos de trabalho bastante relevantes em para fins de comércio exterior o SGT $\mathrm{n}^{\circ}$. 3 (Regulamentos Técnicos e Avaliação de Conformidade), o SGT n. 8 (Agricultura) e o SGT n'. 11 (Saúde), pois neles são discutidas questões relativas à harmonização dos regulamentos técnicos do MERCOSUL relativos a essas searas, a fim de que esses regulamentos e os procedimentos de conformidade nacionais não constituam barreiras técnicas ao comércio intrabloco.

A CCM é o órgão mais técnico entre essas três instancias principais. A ela cabe a aplicação da política comercial do bloco, tanto no que se refere às relações entre os países do MERCOSUL quanto com países de fora. Também compete à CCM a criação de Comitês Técnicos, os quais constituem órgãos de assessoria especializados em temas específicos, os quais elaboram estudos técnicos e emitem pareceres sobre temas determinados. Sua composição é semelhante à do $\mathrm{GMC}$ e a coordenação cabe ao Ministério das Relações Exteriores, e suas manifestações podem ser de duas naturezas diferentes: Diretrizes (obrigatórias para os Estados-membros) e Propostas (recomendações não obrigatórias).

Existem, atualmente, os seguintes 8 Comitês Técnicos associados à CCM:

a) $\mathrm{CT} n^{\circ}$. 1: Tarifas, Nomenclatura e Classificação de Mercadorias;

b) $\mathrm{CT} \mathrm{n}^{\circ}$. 2: Assuntos Aduaneiros; 
c) CT n . 3: Normas e Disciplinas Comerciais;

d) CT n. 4: Políticas Públicas que Distorcem a Competitividade;

e) CT n ${ }^{\circ}$. 5: Defesa da Concorrência;

f) CT n . 6: Estatísticas de Comércio Exterior;

g) CT n ${ }^{\circ}$. 7: Defesa do Consumidor;

h) $\mathrm{CT} n^{\circ}$. 8: Defesa Comercial e Salvaguardas.

Entre esses Comitês Técnicos, cabe destacar que o CT $\mathrm{n}^{0}$. 1, que tem por responsabilidade tratar de questões referentes a tarifas, nomenclatura e classificação aduaneira. É atribuição do $\mathrm{CT} \mathrm{n}^{\circ}$. 1 promover as negociações a respeito de mudanças de nomenclatura ou de alterações definitivas na TEC, exigindo-se consenso entre todos os Estados parte. Conforme se verá no capítulo seguinte, a dinâmica de funcionamento do CT 1 tem impactos importantes sobre os setores produtivos da economia brasileira.

\subsubsection{A condição de integração atual do MERCOSUL e a Tarifa Externa Comum}

Conforme enunciado no artigo $1^{\circ}$ do Tratado de Assunção, o objetivo do MERCOSUL é estabelecer um mercado comum entre seus membros associados. Contudo, desde $1^{\circ}$ de janeiro de 1995, e ainda hoje, o MERCOSUL, tecnicamente, constitui apenas uma união aduaneira.

A união aduaneira e o mercado comum representam, respectivamente, o segundo e o terceiro níveis de uma classificação de quatro níveis de integração multilateral definida pelo GATT, quais sejam: zona de livre comércio, união aduaneira, mercado comum e união econômica. A zona de livre comércio consiste na etapa de integração em que ocorre a eliminação de todas as barreiras alfandegárias, tributárias e não tributárias, incidentes sobre o comércio entre os membros da união. Pressupõe, portanto, a ausência de tributos tanto de importação quanto de exportação incidentes sobre o comércio intrabloco.

A união aduaneira é um nível mais avançado de integração do que a zona de livre comércio, pressupõe a liberalização alfandegária intrabloco com a adoção de uma tarifa externa comum - tabela única de impostos de importação, adotada por todos os países da união, para produtos provenientes de terceiros países. Tem-se, assim, a formação de um único território aduaneiro, constituído por vários territórios nacionais. 
Para alcançar a condição de mercado comum, como prevê seu tratado constitutivo, o MERCOSUL precisará ir além da adoção da TEC, e possibilitar a livre circulação de serviços e de fatores de produção (trabalho e capital) entre seus paísesmembros e todos os países do bloco deverão seguir as mesmas orientações de políticas macroeconômicas (monetária, fiscal e cambial). O único nível de integração mais avançado do que o mercado comum seria a união econômica e monetária, na qual, além das políticas macroeconômicas, os Estados também adotam moeda e banco central comuns, a fim de permitir uma política econômica totalmente unificada. Até o momento, apenas a União Europeia foi capaz de alcançar essa condição, e o MERCOSUL não tem essa pretensão.

O MERCOSUL, atualmente, constitui uma união aduaneira, tendo em vista que possui livre circulação de bens internamente, uma política aduaneira própria e uma tarifa externa comum (TEC) em relação a terceiros países.

A desgravação tarifária entre os países do bloco obedeceu o Programa de Liberalização Comercial estabelecido no Anexo I do Tratado de Assunção, foi feita de maneira progressiva, automática e linear e seguiu o cronograma iniciado em 30/06/1991 e encerrado em 31/12/1994. Não obstante, levando em conta os interesses específicos de cada país e seus diferentes níveis de competitividade, que dificultavam a completa liberalização do comércio intrazona, o Programa permitiu aos países excluir do plano de liberalização um determinado número de mercadorias por um determinado período de tempo. As mercadorias foram incluídas em listas de exceções, sujeitas a reduções automáticas, que duraram até 31/12/1994 para Argentina e Brasil e até 31/12/1995 para Paraguai e Uruguai. Os dois únicos setores não incluídos no Programa de Liberalização, e que permanecem com o comércio tributado dentro do bloco, são o setor açucareiro e o setor automotivo, o primeiro em razão de políticas protecionistas adotadas por Argentina e Uruguai, e o segundo em razão da política automotiva argentina (BAPTISTA, 2010).

A tributação das importações do MERCOSUL em relação a terceiros países é determinada pela Tarifa Externa Comum. Para a elaboração da TEC, foi estabelecido um subgrupo de trabalho específico, o SGT 10, encarregado de definir critérios para definição das tarifas e promover a negociação entre os países. Paralelamente, outro subgrupo de trabalho, o SGT 1 , trabalhou na elaboração de uma nomenclatura 
comum $^{32}$, a NCM - Nomenclatura Comum do MERCOSUL. A NCM foi elaborada com base no Sistema Harmonizado de Classificação de Mercadorias de 1982 (sistema mundial de classificação de mercadorias), que utiliza seis dígitos de abertura, e acrescentou mais dois dígitos, de modo a atender a necessidade de especificação de mercadorias dos países do bloco.

As negociações para o estabelecimento da TEC foram árduas e estenderam-se de 1991 a 1994. No início do processo, em 1991, Argentina, Brasil e Uruguai realizaram reformas de suas estruturas tarifárias que reduziram os níveis absolutos e de dispersão das alíquotas, o que tendia a facilitar as negociações da TEC ${ }^{33}$. Apesar disso, os países, que tinham níveis de desenvolvimento econômico e industrial muito díspares, posicionaram-se nas negociações procurando defender interesses setoriais próprios e, na medida do possível, tentando aproximar a TEC de suas estruturas tarifárias nacionais (BAPTISTA, 2010). Para se alcançar a convergência entre os países, foram necessárias muitas negociações em nível de bloco, no âmbito do SGT 10, e em nível nacional, dos governos com seus setores privados. Finalmente, em agosto de 1994, o projeto de Tarifa Externa Comum elaborado pelo SGT 10 foi aprovado pela CMC, e a TEC entrou em vigor em $1^{\circ}$ de janeiro de $1995^{34}$, conforme previsto pelo Tratado de Assunção.

Ao longo do processo de negociação da TEC, o SGT 10 estabeleceu alguns princípios balizadores para o estabelecimento da estrutura tarifária, entre os quais Baptista (2010) destaca:

a) a tarifa deve ser o único instrumento de proteção da atividade econômica (conforme acordado no âmbito do GATT);

b) a TEC não deve ser discriminatória em favor de algum setor particular;

c) como regra geral, sempre que possível, os produtos não produzidos dentro do bloco devem ser gravados com alíquotas menores;

d) a escalada tarifária (aumento do nível tarifário de acordo com o grau de elaboração do produto) deve ser utilizada como meio para alcançar maior proteção efetiva;

\footnotetext{
32 A nomenclatura consiste no código de classificação aduaneira do produto.

33 Trata-se, no Brasil, da reforma tarifária promovida pelo governo Collor, no contexto de abertura econômica do país. Em decorrência disso, entre 1990 e 1993, a tarifa nominal media foi reduzida de $32,2 \%$ para $14,2 \%$, e tarifa modal caiu de $40 \%$ para $20 \%$. Baptista (2010) destaca que a reforma brasileira aproximou a estrutura tarifária do país a dos demais países da região.

34 A normativa que aprovou a proposta de Tarifa Externa Comum do SGT10 foi a Decisão CMC $7 / 94$.
} 
e) a TEC deve contar com um número pequeno de alíquotas e com baixa dispersão tarifária (desvio padrão em relação à média)

A TEC contempla alíquotas que variam entre $0 \%$ e $20 \%$, em intervalos de dois pontos percentuais, respeitando o princípio da escalada tarifária e adotando-se alíquotas mais baixas para bens não produzidos no bloco. Para bens não produzidos, via de regra, é adotada a alíquota de $2 \%$, de modo a manter uma margem de negociação do bloco em relação a terceiros países (BAPTISTA, 2010). A alíquota de $0 \%$ aplica-se excepcionalmente a mercadorias não produzidas de algumas categorias ${ }^{35}$. Qualquer alteração definitiva na TEC tem de ser definida pelo GMC, mediante a edição de Resolução, e deve limitar-se ao nível da tarifa modal do capítulo correspondente ${ }^{36}$. $\mathrm{Na}$ prática, as alterações da TEC são deliberadas no âmbito do CT $n^{\circ}$. 1, elevadas deste à CCM e desta ao GMC. Em casos excepcionais, é possível ao CMC admitir a adoção de uma TEC superior a 20\% (a exemplo da TEC de 35\% adotada por Brasil e Argentina para produtos do setor automotivo).

Com a criação da TEC, foi autorizado aos países manter uma Lista de Exceções, a LETEC, cujo objetivo é permitir uma margem de autonomia aduaneira para os países, considerando suas assimetrias e diferenças no nível de competitividade. A LETEC possibilita a adoção de alíquotas distintas da TEC para acima ou para abaixo, para uma lista determinada de produtos e por um período limitado de tempo. A intenção inicial era que as LETEC de cada país convergissem progressivamente para a TEC, de modo a eliminar todas as exceções, mas o que tem ocorrido são prorrogações sucessivas da LETEC pelo CMC.

A atual normativa do MERCOSUL que disciplina as listas de exceção é a Decisão CMC $n^{\circ}$. 26/15, a qual estabelece condições e prazos diferenciados para a LETEC de cada país, conforme sua condição de desenvolvimento relativo ${ }^{37}$ :

\footnotetext{
35 Essas categorias são: sementes, animais reprodutores, petróleo, fertilizantes, medicamentos para AIDS, câncer, hepatite C e transplantes, Bens de Capital (BK) e Bens de Informática e Telecomunicações (BIT), desde que não produzidos no Mercosul. (Fonte: MDIC).

36 O capítulo corresponde aos dois primeiros dígitos da classificação aduaneira da mercadoria pelo Sistema Harmonizado. A tarifa modal do capítulo é a tarifa mais comum dos produtos daquele capítulo e, segundo essa orientação, deve ser a alíquota máxima adotada para as mercadorias nele classificadas.

37 As seguintes normativas anteriores também disciplinam a TEC e a LETEC: Decisões $\mathrm{N}^{\circ}$ 07/94, 22/94, 68/00, 31/03, 38/05, 59/07, 28/09 e 58/10 do Conselho do Mercado Comum.
} 
a) República Argentina: até 100 códigos NCM até 31 de dezembro de 2021.

b) República Federativa do Brasil: até 100 códigos NCM até 31 de dezembro de 2021.

c) República do Paraguai: até 649 códigos NCM até 31 de dezembro de 2023.

d) República Oriental do Uruguai: até 225 códigos NCM até 31 de dezembro de 2022.

e) República Bolivariana da Venezuela: até 225 códigos NCM até 31 de dezembro de 2022.

A permanência da LETEC, conjugada com outros mecanismos nacionais de exceção à TEC e com as dificuldades de eliminação da dupla cobrança da TEC, fazem com que o MERCOSUL seja atualmente considerado uma união aduaneira imperfeita ${ }^{38}$.

As consequências impostas ao Brasil pela estrutura e pela dinâmica tarifária do MERCOSUL serão analisadas no próximo capítulo.

38 Existem outros mecanismos de exceção à TEC além da LETEC, como o regime de draw back e de admissão temporária, a adoção dos Ex-tarifários, a prerrogativa de redução tarifária decorrente de situação de desabastecimento interno (prevista na Resolução GMC $n^{\circ}$. 08/08), tributação diferenciada para bens de informática e de comunicação, e todos os regimes especiais de importação adotados por cada país. A dupla cobrança da TEC refere-se à situação em que uma mercadoria importada sofre cobrança da TEC ao ingressar em um dos países do MERCOSUL e, ao ser exportada a outro país do bloco, é novamente tributada pela TEC, por não ter sido produzida internamente. Não cabe, aqui, analisar em detalhe todas essas situações. (algumas delas serão melhor exploradas no próximo capítulo). Basta expô-las a fim de demonstrar o quão longe de uma união aduaneira perfeita está o MERCOSUL. 


\section{AS INSTITUIÇÕES E O COMÉRCIO EXTERIOR NO BRASIL ATUALMENTE}

As normas que regulam as operações de comércio exterior no Brasil são fixadas pelas autoridades públicas competentes, que, na sua formulação, são orientados - ou desorientados - pelos objetivos das políticas públicas vigentes ${ }^{39}$ e pelos compromissos assumidos pelo país no plano internacional. As instituições que atuam sobre o comércio exterior brasileiro, portanto, são resultado da construção de políticas de comércio exterior pelos sucessivos governos associadas à evolução do regime internacional de comércio em suas dimensões multilateral e regional, embora nem todos os aspectos institucionais nacionais estejam necessariamente associados a acordos internacionais.

Não sendo possível cobrir todo o universo das instituições que impactam o comércio internacional brasileiro, este capítulo será dedicado à análise de três aspectos considerados fundamentais à promoção da integração e da competitividade das empresas brasileiras no mercado internacional: as tarifas, os tributos internos e as fontes de crédito público às exportações.

\subsection{Tarifas: a complexidade do regime internacional e seus impactos para a política comercial brasileira}

As tarifas (que no Brasil correspondem ao Imposto de Importação) já foram a principal preocupação dos esforços pela liberalização comercial internacional ${ }^{40}$. Até o início dos anos 2000, os acordos multilaterais e regionais de comércio foram amplamente empregados com o objetivo de promover a liberalização e o crescimento dos fluxos internacionais de comércio $^{41}$. Atualmente (maio de 2016), existem 283

\footnotetext{
39 Não queremos, aqui, entrar na discussão quanto à clareza ou à qualidade dos objetivos de políticas de comércio exterior estabelecidos pelos governos do período em questão; até porque, mesmo a falta de objetivos claros ou a fixação de maus objetivos são aspectos que refletem na elaboração de normas e diretrizes pelo ente público. Ou seja, tanto boas quanto más orientações, ou quanto a falta de orientação, produzem reflexos na construção das instituições.

40 Nesse sentido, afirma Lipson (1983, p. 424): "In the nineteenth century and the twentieth, the most durable aim of trade liberalization has been the reduction of tariffs".

41 A OMC define como acordos regionais de comércio (na sigla em inglês, RTA - regional trade agreements) aqueles reciprocamente estabelecidos entre dois ou mais parceiros, incluindo acordos de livre comércio e uniões aduaneiras. Acordos regionais não se confundem com acordos preferenciais de comércio (na sigla em inglês, PTA - preferencial trade agreements), que são definidos pela OMC como acordos de preferência unilaterais, a exemplo dos estabelecidos sob o Sistema Geral de Preferências (SGP) ou sob outros formatos autorizados
} 
acordos regionais de comércio notificados à $\mathrm{OMC}$ e em vigor. O Brasil está inserido nos dois contextos, tanto o do sistema multilateral de comércio quanto o dos acordos regionais, e ambos operam como limitadores à autonomia brasileira em relação à sua política tarifária (BONELLI et al, 1997, p. 6). Verifica-se, assim, uma necessária integração entre as instituições domésticas e as instituições internacionais.

Como membro da $\mathrm{OMC}$, o Brasil está restrito a um teto máximo tarifário por código de mercadoria, estabelecido em uma listagem junto à organização, conforme determina o GATT. As tarifas máximas fixadas junto à OMC são denominadas tarifas consolidadas. As tarifas brasileiras consolidadas na OMC variam entre $0 \%$ e $55 \%$, mas a maior parte dos produtos têm suas tarifas consolidadas em 35\% (cerca de 6.600 códigos tarifários de um universo de 10.460 , representando aproximadamente $63 \%)^{42}$. Essas são as tarifas máximas que o Brasil pode adotar para cada tipo de mercadoria no comércio com os demais membros da OMC.

Com a instituição do MERCOSUL e a adoção da TEC, o Brasil passou a ter um segundo nível de compromissos tarifários internacionais, em âmbito regional. No caso da TEC, contudo, tratam-se de tarifas de adoção obrigatória pelo Brasil, e não de nível tarifário máximo, como ocorre na OMC. As tarifas estabelecidas na TEC foram definidas em conjunto pelos países do bloco nos primeiros anos após sua constituição e, atualmente, suas alterações são definidas pelo CT-1 (ligado à CCM) em função de pleitos que são apresentados pelos países, exigindo-se a deliberação por consenso. As mudanças da TEC definidas pelo CT1 são, então, incorporadas ao ordenamento jurídico brasileiro por meio de Resolução CAMEX. Com relação a concessões tarifárias em relação a terceiros países, em decorrência da Decisão $C M C n^{0}$. 32/00, os países só podem realizar negociações em bloco, e nunca unilateralmente.

Em vista disso, de maneira geral, o Brasil deixou de ter autonomia para fixar suas tarifas, ressalvados alguns casos excepcionais. As principais exceções em relação à política aduaneira comum são a Lista de Exceção à TEC, a hipótese de desabastecimento nacional prevista na Resolução GMC n. 08/08 e o Ex-tarifário. Enquanto a LETEC possibilita ao país adotar alíquotas acima ou abaixo da TEC, mantendo o produto na lista enquanto Ihe convier, a Resolução GMC $n^{\circ} .08 / 08$ autoriza

(por waiver) pelo Conselho Geral. Atualmente, constam na OMC 28 acordos de preferência comercial em vigor.

42 A relação completa das tarifas brasileiras consolidadas na OMC pode ser obtida no sítio eletrônico do MDIC, pelo endereço

$<$ http://www.desenvolvimento.gov.br/sitio/interna/interna.php?area=5\&menu=372>. 
apenas a redução da alíquota, e por prazo determinado. Já o Ex-tarifário permite a redução das tarifas para bens de capital, de informática e de telecomunicações não produzidos no país.

Conforme definido na Decisão CMC 26/15, o Brasil é autorizado a manter 100 códigos na LETEC até 31 de dezembro de 2015, sendo-lhe permitido alterar até 20\% desses códigos a cada seis meses. Com relação à situação de desabastecimento, todos os países são limitados a 45 códigos simultâneos (excepcionadas as situações de calamidade ou risco à saúde pública, que não são computados no limite), a quantidade a importar deve ser previamente determinada e as alíquotas reduzidas não poderão ser inferiores a $2 \%$ (excepcionados os casos em que a CCM autorizar reduções de alíquota a $0 \%$ ). Cabe destacar que, enquanto os códigos da LETEC são livremente estabelecidos por cada país, todos os pleitos de redução tarifária ao amparo da Resolução GMC 08/08 devem ser submetidos à aprovação dos demais Estados parte do MERCOSUL, no âmbito da CCM.

O Ex-tarifário consiste na redução temporária do Imposto de Importação para $2 \%$, pelo período de dois anos, para bens de capital $(B K)$ e bens de informática e telecomunicações (BIT), assim como para suas partes, peças e componentes, quando não houver produção nacional do bem. O objetivo da concessão é possibilitar a modernização do parque industrial e a melhoria dos serviços de telecomunicações no país. Para obter o benefício, o importador brasileiro deve realizar um pleito junto à Secretaria do Desenvolvimento e da Competitividade Industrial do MDIC, que o submeterá ao Comitê de Análises de "Ex-tarifários" (CAEx), no âmbito do Ministério. Após a análise técnica do Comitê, que verifica, por exemplo, a inexistência de produção nacional, o pleito é submetido à aprovação da CAMEX, criando-se um destaque tarifário (denominado Ex-tarifário) para aquele produto dentro do seu código tarifário da LETEC. Nota-se, portanto, que a adoção desse mecanismo de exceção da TEC prescinde de qualquer tipo de aprovação pelos demais Estados-partes do MERCOSUL.

A excepcionalidade tarifária para BK e BIT vigora no bloco desde 1994, quando a previsão para a convergência das tarifas à TEC era $1^{\circ}$ de janeiro de 2001 para bens de capital e $1^{\circ}$ de janeiro de 2006 para bens de informática (de acordo com a Decisão CMC $n^{\circ}$. 7/94). Contudo, a concessão vem sendo sucessivamente prorrogada e, atualmente, a previsão de entrada em vigor do regime comum para BK é em $1^{\circ}$ de janeiro de 2022 para Brasil e Argentina e $1^{\circ}$ de janeiro de 2024 para os demais países (conforme Decisão CMC $\mathrm{n}^{\circ}$. 25/15, normativa mais recente a disciplinar o assunto). 
Para BIT, o início do regime comum está previsto para $1^{\circ}$ de janeiro de 2022 , sendo permitido ao Uruguai e à Venezuela manter exceções até 31 de dezembro de 2022, e ao Paraguai até 31 de dezembro de 2023 (também conforme Decisão CMC n. 25/15).

Existe um outro mecanismo de exceção à TEC, estabelecido pela Decisão CMC $n^{\circ}$. 39/11, que autorizou os países a elevar a TEC de maneira transitória em decorrência de desequilíbrios comerciais decorrentes da conjuntura econômica internacional. A elevação poderia ser adotada para até 100 códigos NCM, para vigorar por um período de 12 meses, prorrogáveis por igual período caso persistissem os desequilíbrios. Para o produtor brasileiro incluir produtos na lista, os pleitos deveriam ser submetidos a análise do Grupo Técnico sobre Alterações Temporárias da TEC (GTAT/TEC), o qual consolidava e analisava os pleitos para depois elevá-los à consideração final da CAMEX. Após a definição pelo governo brasileiro, o pleito era informado aos demais Estados Partes e, não havendo objeção no prazo de 15 dias, o Brasil poderia automaticamente implementar a elevação.

A Decisão CMC n'. 39/11 vigorou até 31 de dezembro de 2014. Em julho de 2015, o mecanismo de elevação temporária foi renovado pela Decisão CMC $n^{\circ}$. 27/15, com vigência até 31 de dezembro de 2021. Contudo, diferentemente do que ocorreu em 2011, desta vez o Brasil não internalizou a normativa do MERCOSUL e, portanto, não vem mais aplicando a elevação tarifaria excepcional da TEC por motivo de desabastecimento. A não internalização deve-se a preocupações do governo quanto aos possíveis impactos negativos de aumentos tarifários sobre os custos de produção da indústria e o nível de preços domésticos, o que poderia contribuir para agravar a atual crise econômica.

Os principais problemas advindos dessa dinâmica de definição de tarifas no MERCOSUL são de duas naturezas.

Em primeiro lugar, os princípios utilizados para a construção da TEC no início da formação do bloco, conforme explicado no capítulo 3 , foram discutidos e definidos pelos negociadores à época, mas não ficaram estabelecidos em nenhuma normativa formal do bloco. Assim, o princípio de adoção da tarifa modal para bens produzidos no bloco, em oposição às tarifas de $2 \%$ ou $0 \%$ para bens não produzidos, acaba sendo uma inferência que se faz a partir do funcionamento efetivo da TEC, mas que não encontra respaldo no ordenamento jurídico do bloco. Por isso, todas as deliberações do CT $n^{\circ} .1$ acerca de pleitos de alterações definitivas da TEC acabam orientados por entendimentos circunstanciais dos negociadores, que não estão obrigados a respeitar 
nenhum critério objetivo. Isso também dá espaço a que, por vezes, as discussões técnicas do Comitê sejam contaminadas por divergências políticas entre os países de outras naturezas.

A consequência disso é que muitos dos pleitos que são levados ao $C T n^{\circ} .1$, sobretudo os de elevação tarifária, permanecem por diversos anos em discussão sem que os países cheguem a nenhuma posição definitiva (nem mesmo de recusa). Existem situações, por exemplo, em que a própria empresa nacional que requisitou a mudança tarifária informa ao seu governo que desiste do pleito, em função do excessivo tempo de espera por uma resposta (há casos em que esse tempo chega quase a uma década). Uma opção do país requerente da mudança, diante do impasse no âmbito do CT $n^{\circ}$. 1, é elevar a discussão ao GMC e deste, permanecendo a controvérsia, ao CMC. Contudo, os relatos são de que a elevação dos pleitos dificilmente leva a soluções satisfatórias.

A morosidade e as incertezas associadas ao processo de alteração definitiva da TEC acabam por prejudicar a previsibilidade do nível tarifário com que as empresas irão deparar no âmbito do bloco, afetando o cálculo de retorno dos investimentos e desincentivando a atração de novas atividades produtivas, que não têm segurança de que poderão contar com a aplicação da tarifa modal. Verifica-se, portanto, um impacto direto da estrutura tarifária do MERCOSUL sobre o desenvolvimento industrial no âmbito regional.

Em segundo lugar, a obrigação imposta pela Decisão $C M C n^{0} .32 / 00$ de que as negociações de acordos comerciais de preferências tarifárias com terceiros países sejam feitas em bloco - onde todas as decisões são tomadas por consenso, cabe lembrar - tem retardado a conclusão de negociações comerciais consideradas prioritárias pelos países do bloco, a exemplo do que vem acontecendo com a União Europeia. Nota-se, com preocupação, que os países do MERCOSUL têm ficado à margem das iniciativas mais recentes e modernas de acordos regionais e plurilaterais de comércio, a exemplo do TPP, do TTIP e do TISA.

Dessa forma, o impedimento dos Estados membros de negociar com terceiros países de maneira unilateral restringe a utilização dos acordos comerciais como instrumento de promoção do comércio exterior e fomento da atividade econômica, e pode estar levando a um isolamento do MERCOSUL no ambiente internacional. 


\subsection{Tributação doméstica: os resíduos tributários e seus impactos sobre a indústria nacional}

A tributação doméstica constitui instituição relevante para o comércio internacional não só na medida em que impacta o valor das mercadorias exportadas, mas também por que constitui variável relevante do chamado "custo Brasil", influenciando as decisões de investimento no país. Cabe destacar que, por tributação doméstica, compreendemos todos os tributos incidentes sobre a comercialização e a circulação de mercadorias ou sobre algum aspecto da atividade empresarial (que acabam repassados no preço dos produtos), excluídos os Impostos de Importação e de Exportação (já tratados na sessão de tarifas). O termo tributo constitui o gênero do qual impostos, taxas e contribuições são espécies.

A estrutura tributária brasileira é bastante complexa, compreendendo diversos tipos de impostos e contribuições que incidem sobre a atividade empresarial. Existem os tributos que impactam diretamente o lucro das empresas, como o Imposto de Renda da Pessoa Jurídica (IRPJ) e a Contribuição Social sobre o Lucro Líquido (CSLL), e existem os que incidem sobre os valores de transação das mercadorias, como o Imposto sobre Produtos Industrializados (IPI), o Imposto sobre a Circulação de Mercadorias e Serviços (ICMS), a contribuição para o Programa de Integração Social (PIS) e a contribuição para o Financiamento da Seguridade Social (COFINS). Além disso, existem também os tributos que oneram a folha de pagamentos dos empresários, como a cota patronal da contribuição para a previdência social (INSS).

As competências para estabelecer cada tipo de tributo e as regras básicas sobre o funcionamento de cada um deles estão estabelecidos pela Constituição Federal de 1988 (CF/88), a qual adota em relação as exportações o princípio da tributação no país de destino ${ }^{43}$. Dessa forma, ICMS, IPI, PIS e COFINS não são tributados sobre as mercadorias exportadas, mas é garantido ao exportador o direito de creditar-se sobre o valor dos tributos indiretos incidentes sobre os insumos utilizados na fabricação dessas mercadorias. Em teoria, essa dinâmica deveria fazer com que o custo dos produtos

43 A CF/88 previu a imunidade tributária dos tributos indiretos sobre as exportações nos seguintes dispositivos: do IPI no art. $153, \S 3^{\circ}$, III; do ICMS no art. $155, \S 2^{\circ}$, X, a; do PIS e da COFINS no art. $149, \S 2^{\circ}$, I. No mesmo sentido, o art. 149 , $\S 20$ da CF/88 estabelece que as contribuições sociais e de intervenção no domínio econômico não incidirão sobre as receitas de exportação. 
exportados fosse livre do impacto dos tributos domésticos, mas isso não é o que acontece na prática.

Em primeiro lugar, existe o impacto de tributos que oneram a atividade produtiva, como a contribuição para o INSS, e que acabam incorporando-se no custo da mercadoria exportada. De acordo com pesquisa realizada pela Confederação Nacional da Indústria (2014) entre seus associados, a maior parte dos empresários considera o INSS como o tributo com maior impacto negativo sobre o custo dos produtos exportados - $65,3 \%$ dos entrevistas afirmaram que a contribuição impacta no valor dos produtos e $26,4 \%$ afirmaram que o impacto é muito grande. Segundo o estudo da CNI, o efeito seria ainda mais negativo para as empresas de menor porte, como micro e pequenas empresas.

Com relação aos tributos que não deveriam impactar as exportações (como o ICMS, o IPI, o PIS e a COFINS), o problema acaba sendo quanto à utilização dos créditos tributários referentes aos insumos de fabricação dos produtos exportados. Quando as empresas não têm vendas suficientes no mercado interno para gerar débito de tributos com os quais compensar os créditos dos insumos das mercadorias exportadas, esses créditos acabam não sendo utilizados. Assim, as empresas ficam dependentes de processos de ressarcimento para que os valores sejam devolvidos pelo governo. No caso do ICMS, em alguns estados, existe também a possibilidade de obter autorização para a venda de crédito a outros contribuintes. Ocorre que esses procedimentos são muito burocráticos e morosos, e o resultado é, muitas vezes, a acumulação dos créditos pelo exportador. Quando as empresas deixam de ter expectativa de recuperação desses valores, eles acabam sendo incorporados ao custo das mercadorias vendidas, prejudicando a competitividade do produto brasileiro no exterior.

Mais de um terço dos exportadores brasileiros consultados pela CNI (2014) consideram o não ressarcimento de créditos uma dificuldade séria para as exportações brasileiras, e aproximadamente metade dos exportadores que possuem créditos acumulados afirma que isso afeta sua decisão de exportação. Dessas, aproximadamente metade afirmam que se sentem desestimuladas e diminuem 0 esforço para exportar, $30 \%$ informam que reduzem as exportações por considerar que a rentabilidade ficou abaixo da esperada e 17\% dizem que restringem as exportações de modo que os créditos tributários não ultrapassem os débitos gerados com as vendas no mercado interno, a fim de não acumular créditos. 
Ao longo das últimas décadas, houve várias tentativas do governo de desoneração das exportações a fim de tentar minimizar esse problema, conforme demonstrado no capítulo 2. Algumas delas concentraram-se em conceder créditos presumidos, como o crédito presumido de IPI; outras, como o regime de draw back, possibilitaram a desoneração dos tributos sobre os insumos de produção (medida mais adequada para evitar a acumulação de créditos). A mais recente dessas medidas foi a instituição, em 2011, de um regime especial destinado à recuperação de resíduos tributários das exportações, o REINTEGRA, na tentativa de eliminar todos os impactos tributários remanescentes sobre a cadeia produtiva das mercadorias exportadas ${ }^{44}$. $O$ regime concedeu ao exportador o direito de calcular um crédito adicional com base na aplicação de determinado percentual sobre as receitas de exportação, o qual pode ser utilizado tanto para compensação de outros débitos quanto para solicitação de ressarcimento. Inicialmente, o percentual para o cálculo do crédito era de $3 \%$.

Quando foi estabelecido, o regime foi considerado uma medida importante para melhorar a competitividade da indústria brasileira e criou uma expectativa positiva entre os exportadores. Contudo, diante da crise fiscal por que vem passando o Estado brasileiro, os percentuais de recuperação tributária foram sendo substancialmente reduzidos ao longo dos anos: em 2015, o percentual caiu de 3\% para 1\% e, em 2016, o percentual será de apenas $0,1 \%$. A previsão é que o percentual suba para $2 \%$ em 2017 e retorne a $3 \%$ apenas em 2018 , mas as expectativas de acentuação do ajuste fiscal brasileiro provocam incertezas quanto a efetivação desse aumento dos percentuais.

Essas mudanças levaram o setor privado a proferir inúmeras críticas junto ao governo. No entanto, os pleitos de retorno do percentual de recuperação do REINTEGRA aos originais 3\% encontram forte resistência no Ministério da Fazenda, em razão das dificuldades que o momento de crise impõe às demandas que exijam renúncia fiscal. Embora compreensível esse posicionamento, cabe lembrar que o aumento das exportações tende a aumentar o lucro tributável das empresas e, por consequência, aumentar a arrecadação do imposto de renda sobre a pessoa jurídica. Ademais, a melhoria dos resultados empresariais tem impactos positivos para os investimentos e para a geração de empregos no setor industrial, gerando efeitos

44 O REINTEGRA - Regime Especial de Reintegração de Valores Tributários - foi instituído pela Lei $n^{\circ}$. 12.546/2011, regulamentada pelo Decreto $n^{\circ}$. 7.633/2011, para ser aplicado até 31/12/2013. Em 2014, o regime foi reinstituído pela Lei $13.043 / 2014$, regulamentada pelos Decretos $n^{\circ} 8.304 / 2014$ (revogado pelo Decreto $n^{\circ}$. 8.415/2015) e $n^{\circ} 8.415 / 2015$ (alterado pelo Decreto $n^{\circ} 8.543 / 2015$ ), para ser aplicado até 31/12/2018. 
multiplicadores sobre a totalidade da atividade econômica com impactos positivos sobre a arrecadação. Ainda que esses resultados não sejam verificáveis a prazos tão curtos quanto os da renúncia fiscal do REINTEGA, cabe lembrar esses argumentos e questionar a sistemática atual do mecanismo.

Outra importante crítica do setor empresarial quanto às mudanças de regra do programa é que, mais do que prejudicar os resultados das empresas em determinado período, elas prejudicam a previsibilidade do negócio em períodos futuros, afetando suas decisões de produção e de investimento. Cabe destacar que queixas quanto à insegurança jurídica decorrentes das mudanças na legislação tributária brasileira não se restringem ao REINTEGRA, mas se estendem a todos os demais tributos. São frequentes, por exemplo, alterações na legislação de ICMS, IPI, PIS e COFINS, e o problema agrava-se pelo fato haver uma legislação específica de cada estado para o ICMS.

Considerando que o sistema tributário brasileiro é complexo e a carga tributária no Brasil é alta, os tributos constituem variável bastante relevante para as decisões de negócio das empresas. Portanto, os altos custos tributários e a falta de previsibilidade provocada pela dinâmica instável do sistema tributário brasileiro prejudicam a competitividade das exportações brasileiras e desestimulam a expansão da atividade produtiva no país.

\subsection{Financiamento e garantia: o funcionamento dos instrumentos de crédito público}

A política brasileira de financiamento e garantia às exportações está inserida no contexto mais amplo das políticas que procuram promover a competitividade das empresas brasileiras no mercado internacional e promover sua internacionalização. Nas últimas décadas, o crescimento dos fluxos comerciais de países emergentes e em desenvolvimento levou à necessidade de se diversificar os mecanismos de financiamento à exportação, com a criação de instrumentos mais adequados a ambientes de maior risco (AVILA; CATERMOL; DIAS, 2015). Além disso, no contexto de crise econômica global que vem atingindo diversos países desde 2008, o financiamento ao comércio exterior ganhou importância como facilitador para os fluxos de comércio internacional (MALAKET, 2015). 
Os instrumentos públicos de financiamento e garantia atuam no sentido de corrigir falhas de mercado, promovendo operações que não são atendidas pelas instituições financeiras privadas, quer por exigirem valores muito altos ou prazos muito longos, quer por envolverem altos riscos. Avila, Catermol e Dias (2015) destacam que a atividade pública de financiamento às exportações leva em consideração não apenas a lucratividade da operação, mas se preocupa também com o efeito para a expansão das empresas nacionais. Já os agentes financeiros privados, além de serem motivados pelo potencial de lucratividade, tem sido cada vez mais contidos pelo potencial de risco das operações, tendo em vista os parâmetros de controle e de resguardo das instituições financeiras que vem sendo impostos por normativas nacionais e internacionais (ASSAD JUNIOR; CARREIRO, 2015). Nesse contexto, ganha ainda mais importância o financiamento público ao comércio exterior.

O crédito público à exportação, contudo, pode ser considerado como subsídio ilegal à exportação. Por isso, sua utilização é regulamentada tanto pela OMC quanto pelo MERCOSUL.

O Anexo do Acordo de Subsídios da OMC estabelece que são considerados subsídios à exportação: i) a concessão de crédito a taxas inferiores às que o governo pagaria para obter os recursos utilizados para o financiamento; ii) o pagamento, pelo governo, da totalidade ou de parte dos custos incorridos pelos exportadores ou por instituições financeiras quando obtêm crédito. Não obstante, o Acordo faz uma concessão e autoriza o crédito público à exportação caso o Estado membro seja parte de compromisso internacional referente a créditos oficiais à exportação, ou quando aplicar as disposições relativas ao juros previstas em tal compromisso ${ }^{45}$. Atualmente, $\mathrm{o}$

45 Segue a redação completa do referido dispositivo, constante no Anexo do Acordo de Subsídios da OMC: (k) A concessão pelo governo (ou por instituições especiais controladas pelas autoridades do governo e/ou agindo sob seu comando) de créditos à exportação a taxas inferiores àquelas pelas quais o governo obtém os recursos utilizados para estabelecer tais créditos (ou que teriam de pagar se tomassem emprestado nos mercados financeiros internacionais recursos com a mesma maturação, nas mesmas condições creditícias e na mesma moeda do crédito à exportação) ou o pagamento pelo governo da totalidade ou de parte dos custos em que incorrem exportadores ou instituições financeiras quando obtêm créditos, na medida em que sejam utilizados para garantir vantagem de monta nas condições dos créditos à exportação.

Não obstante, se um Membro é parte de compromisso internacional em matéria de créditos oficiais à exportação do qual sejam partes pelo menos 12 Membros originais do presente Acordo em $1^{\circ}$ de janeiro de 1979 (ou de compromisso que tenha substituído o primeiro e que tenha sido aceito por esses Membros originais), ou se na prática um Membro aplica as disposições relativas ao tipo de juros do compromisso correspondente, uma prática adotada em matéria de crédito à 
tema está disciplinado em Acordo sobre Normas de Conduta para Apoio Oficial em Créditos à Exportação da OCDE (Arrangement on Guidelines for Officially Supported Export Credits), de 1978, do qual o Brasil não é parte ${ }^{46}$. No entanto, a fim de reduzir os riscos de questionamento internacional sobre seus programas de crédito oficial, o Brasil utiliza como parâmetros operacionais as disposições do Acordo.

Com relação ao MERCOSUL, a Decisão CMC 10/94 estabeleceu que os créditos de fomento e financiamentos públicos às exportações dentro do bloco deverão observar as condições de prazos e taxas de juros utilizados em operações equivalentes no mercado internacional, reforçando o que estabeleceu o Acordo de Subsídios da OMC.

Conforme verifica-se no capítulo 2, o sistema público brasileiro de financiamento às exportações ganhou seus contornos durante o período do governo militar, quando foram criados instrumentos importantes de financiamento e de equalização. Apesar dos retrocessos que o sistema sofreu na década de 1980, o Estado vem sendo reaparelhado de seus instrumentos de financiamento e garantia ao longo das últimas décadas. Como resultado, atualmente, o exportador brasileiro conta com linhas de financiamento e de equalização oferecidas pelo Tesouro Nacional e pelo BNDES, amparadas Fundo Garantidor de Crédito (FGE).

O Programa de Financiamento às Exportações (PROEX-Financiamento) é a linha de financiamento realizada com recursos do Tesouro Nacional, mas as operações são realizadas por meio do Banco do Brasil (BB), seu agente executor. O PROEXFinanciamento tem por objetivo financiar exportações de bens e serviços de empresas com faturamento bruto anual de até 600 milhões de reais (exceto se as operações decorrerem de acordos bilaterais, casos em que não é necessário observar esse limite), com foco em micro, pequenas e médias empresas ${ }^{47}$. $O$ crédito pode ser concedido tanto

exportação que esteja em conformidade com essas disposições não será considerada como subsídio à exportação proibido pelo presente Acordo.

${ }^{46}$ Cabe destacar que, apesar de não ser parte do acordo geral, o Brasil é parte do acordo específico sobre aviação civil (Entendimento no Setor da Aviação sobre Créditos à Exportação para Aeronaves Civis).

47 De acordo com classificação do BNDES, as empresas são classificadas de acordo com o seguinte critério de faturamento anual: microempresa - faturamento menor ou igual a $R \$ 2,4$ milhões; pequena empresa - faturamento maior que $R \$ 2,4$ milhões e menor ou igual a $R \$ 16$ milhões; média empresa - faturamento maior que $R \$ 16$ milhões e menor ou igual a $R \$ 90$ milhões; empresa média-grande - faturamento maior que $R \$ 90$ milhões e menor igual a $R \$ 300$ milhões; grande empresa - faturamento maior que $\mathrm{R} \$ 300$ milhões. 
ao exportador brasileiro quanto ao importador no exterior, e os prazos para pagamento variam entre 60 dias e 10 anos.

O Tesouro Nacional também viabiliza um mecanismo de equalização de taxas de juros, denominado PROEX-Equalização. O objetivo desse programa é equiparar a taxa de juros paga pelo contratante à taxa de juros praticada no mercado internacional, sendo a diferença entre a taxa internacional e a taxa do financiamento doméstico (chamada spread) coberta pelo Tesouro por meio da emissão de Notas do Tesouro Nacional, série I (NTN-I). O beneficiário da equalização é a instituição financiadora da exportação brasileira, nas operações de financiamento ao importador ou para refinanciamento ao exportador, e o programa é aplicável a empresas de qualquer porte. Os prazos da operação variam de 60 dias a 15 anos e não necessariamente precisam ser coincidentes com os da operação de financiamento.

Existe uma outra linha menor do Banco do Brasil, denominada Proger Exportação, que se destina a financiar exportações de bens produzidos por empresas com faturamento bruto anual de até cinco milhões de reais. Diferentemente das outras linhas, o Proger pode ser utilizado inclusive para despesas com promoção comercial no exterior, como para a participação em feiras. Este, contudo, é um mecanismo de crédito bastante restrito, pois alcança apenas micro e pequenas empresas e concede no máximo 250 mil reais por operações.

Outro agente público financiador das exportações é o BNDES, por meio de um programa denominado BNDES-Exim. O objetivo das linhas do BNDES-Exim é propiciar condições competitivas em comparação com o mercado internacional para exportações de bens e serviços. O programa atende tanto operações pré-embarque (para financiar a produção de bens ou serviços a serem exportados, realizados por instituições financeiras credenciadas) quanto pós-embarque (para financiar a exportações de serviços ou produtos acabados, contratados diretamente com o BNDES). Os beneficiários do BDES-Exim podem ser empresas de qualquer porte, desde que tenham sede e administração no Brasil. Cabe destacar que o BNDES constitui a principal fonte de financiamento público de longo prazo para o comércio exterior no Brasil (AVILA; CATERMOL; DIAS, 2015).

Com relação à garantia, o mecanismo disponibilizado pelo governo é o Seguro de Crédito à Exportação (SCE), amparado por recursos do Fundo de Garantia à Exportação (FGE) - fundo de natureza contábil vinculado ao Ministério da Fazenda. A finalidade do SCE é cobrir as operações quanto a riscos de natureza comercial, política 
ou extraordinária e pode ser concedido aos exportadores ou às instituições financeiras e agências de crédito que os financie. O SCE pode ser concedido a operações de micro, pequenas e médias empresas, com prazo de até dois anos, ou a empresas de maior porte e com prazos superiores a cinco anos. Além disso, existe uma cobertura especial relacionada a operações com risco político ou extraordinário, para operações com prazo inferior a dois anos ${ }^{48}$.

O FGE é o único mecanismo público de garantia em nível nacional. A despeito disso, existe um importante instrumento de mitigação de risco político estabelecido no âmbito da ALADI, o Convênio de Pagamentos e Créditos Recíprocos (CCR). O convênio, estabelecido em 1982, contempla todos os países do bloco mais a República Dominicana e funciona como um mecanismo de compensação multilateral de pagamentos internacionais, com a liquidação das contas ativas e passivas dos países entre si a cada quadrimestre, o que reduz o risco de que os países não honrem seus pagamentos. Além desse benefício, destaca Fonseca (2015), o sistema permite aos países minimizar os desembolsos de suas escassas reservas cambiais ${ }^{49}$.

Segundo levantamento feito pela CNI (2014) entre seus associados, a utilização de linhas oficiais de financiamento ainda é pequena entre o público empresarial: apenas $14,1 \%$ das 639 empresas entrevistadas utiliza algum desses instrumentos. Boa parte das empresas não utiliza as linhas porque sequer as conhece: o desconhecimento do Proex-Financiamento e do Proger Exportação é de mais de $30 \%$, enquanto do FGE é de quase $70 \%$. Nos casos das empresas que conhecem as linhas, muitas informam desinteresse em utilizá-las, alegando que as condições não atendem a suas necessidades. Além disso, existem empresas que têm interesse em utilizar as linhas, mas não conseguem cumprir as exigências de garantias reais e de documentação impostas pelo agente financiador ou garantidor. Com relação às operações que se efetivam, a maior crítica feita é com relação ao fato de os financiamentos serem

48 Risco politico é o risco associado ao não pagamento da obrigação em razão da impossibilidade de remessas de divisas ao exportador imposta, deliberadamente ou não, pelo governo do país do importador; enquanto o risco extraordinário está associado a situações de calamidades e desastres naturais. Os dois se diferenciam do risco comercial, que consiste na impossibilidade de pagamento do exportador devido à insolvência do importador.

${ }^{49}$ Fonseca (2015, p. 38) ressalta que, graças ao CCR, foi possível os países latino-americanos manterem os níveis de comércio internacional durante os anos de crise da dívida externa, na década de 1980: "Mesmo durante o crítico período de moratória de pagamentos da dívida externa de diversos países-membros da Aladi, inclusive o Brasil (1987), o fluxo de liquidações multilaterais do CCR continuou a ser plenamente honrado". 
majoritariamente destinados a empresas de grande porte, com especial concentração em alguns setores específicos, como aeronáutico, automotivo e de serviços de engenharia pesada (FONSECA, 2015).

Os gráficos abaixo demonstram a discrepância no volume de recursos despendidos pelo BNDES, ao longo dos anos, com financiamentos de empresas de grande porte em relação às demais categorias de empresas. Verifica-se que, dos mais de 150 milhões de reais de desembolsos em 2015, aproximadamente 120 milhões $(80 \%)$ foram destinados a grandes empresas, enquanto todo o restante distribuiu-se entre médias, pequenas e microempresas (na proporção aproximada de 1/4, 1/4 e 2/4, respectivamente) $)^{50}$.

Gráfico 1 - Desembolsos anuais do BNDES com financiamentos totais

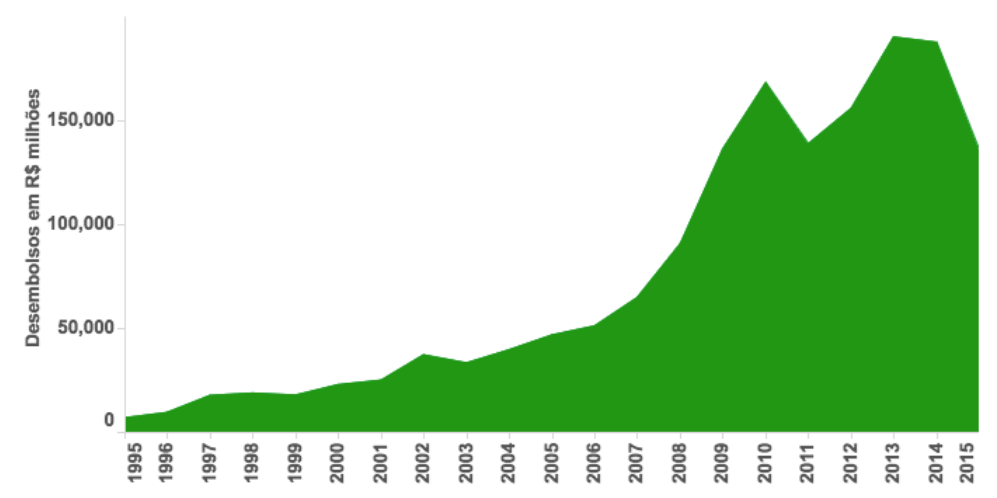

Fonte: BNDES.

50 Cabe destacar que não existe a disponibilização dessas mesmas informações em relação aos demais instrumentos de financiamento, por isso as análises quantitativas estão restritas ao instrumento do BNDES. Deixamos a crítica quanto à transparência das informações em relação às operações do PROEX. 
Gráfico 2 - Desembolsos anuais do BNDES com financiamentos de grandes empresas

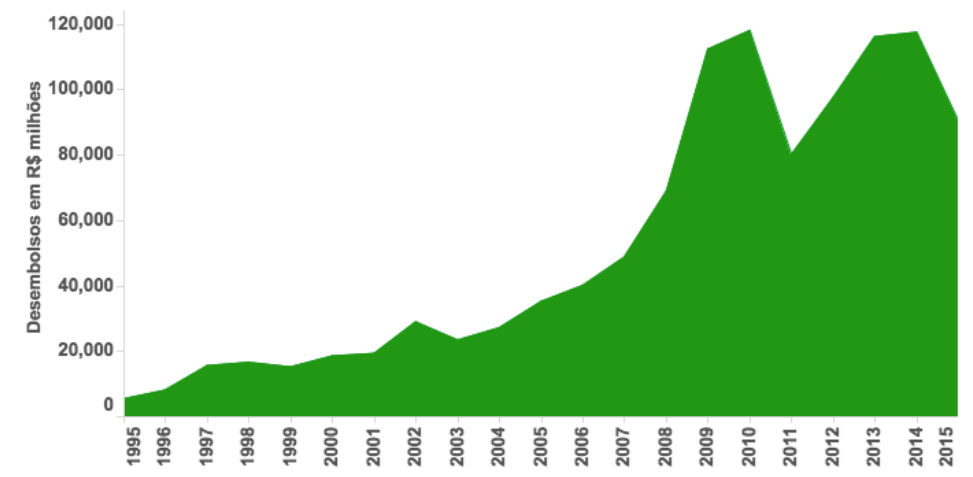

Fonte: BNDES.

Gráfico 3 - Desembolsos anuais do BNDES com financiamentos de empresas médiagrandes (conforme classificação iniciada em 2010)

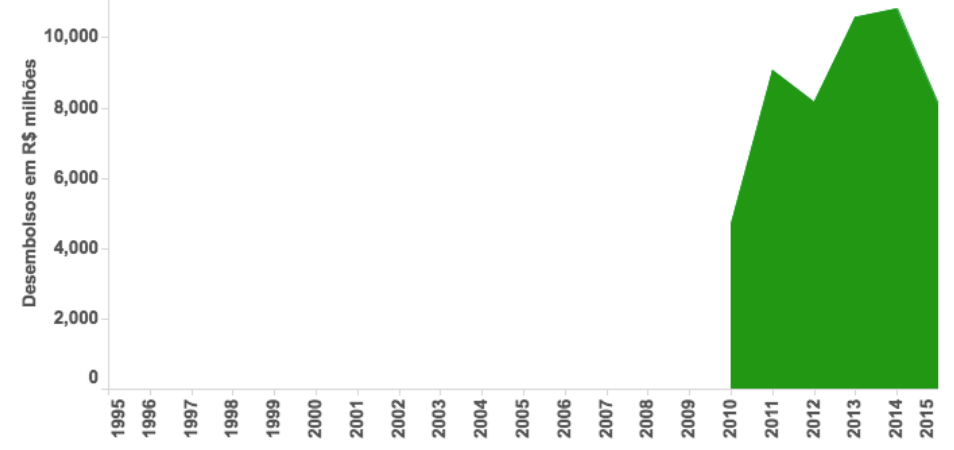

Fonte: BNDES.

Gráfico 4 - Desembolsos anuais do BNDES com financiamentos de médias empresas

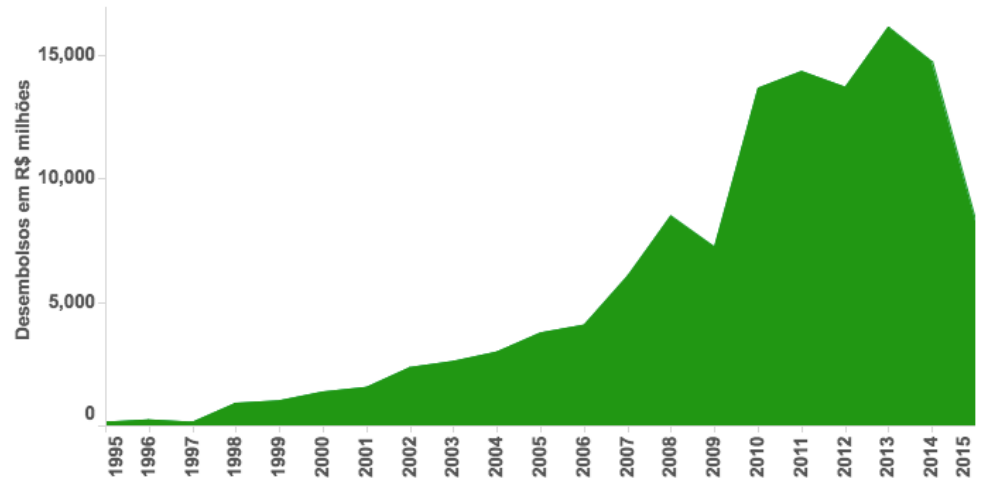

Fonte: BNDES. 
Gráfico 5 - Desembolsos anuais do BNDES com financiamentos de pequenas empresas

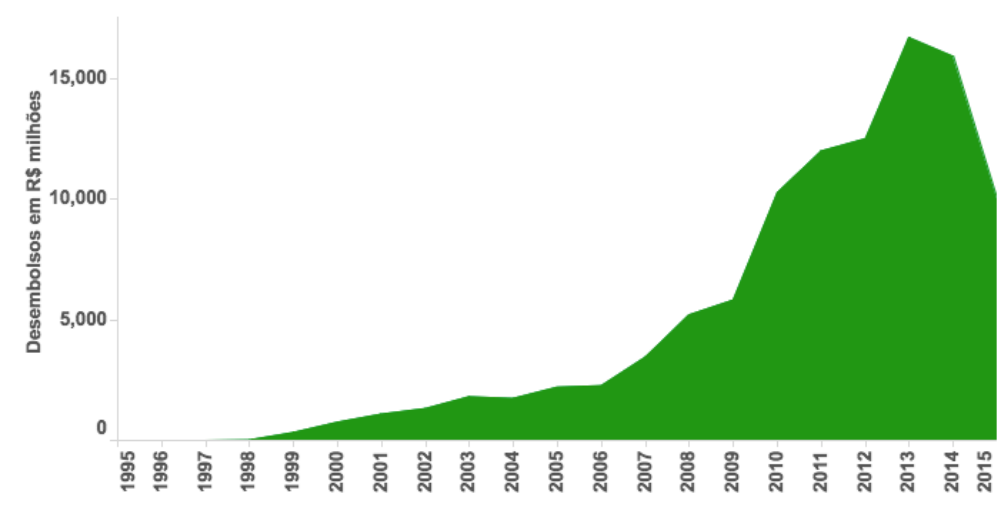

Fonte: BNDES.

Gráfico 6 - Desembolsos anuais do BNDES com financiamentos de microempresas

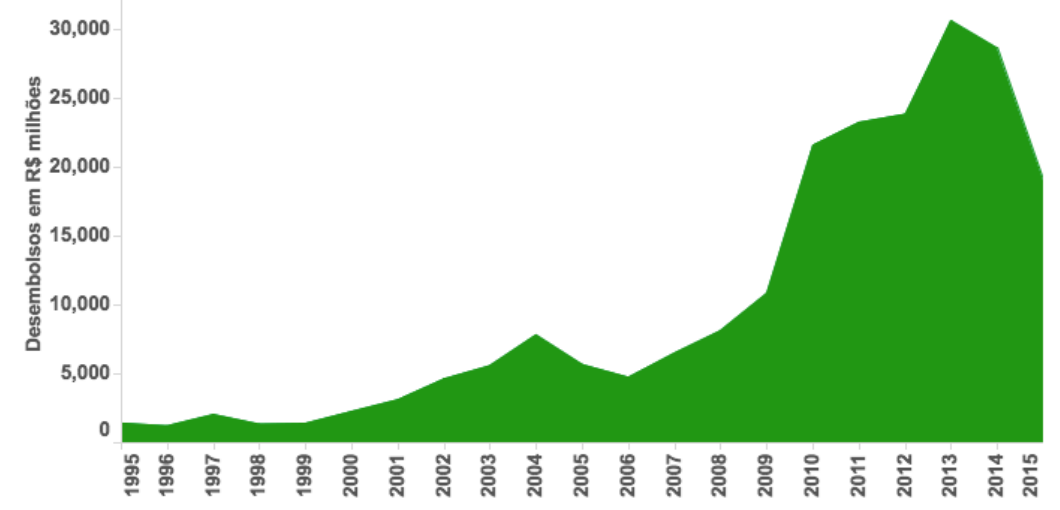

Fonte: BNDES.

Além da concentração do crédito em um número baixo de empresas exportadoras, outra importante deficiência do sistema brasileiro de financiamento às exportações é a falta de fontes financiadoras para operações de longo prazo e a baixa integração com instituições financeiras internacionais, em operações de cofinanciamento $^{51}$ (AVILA; CATERMOL; DIAS, 2015), bem como a falta de integração

51 Esse tipo de financiamento conjunto, por instituições de diferentes países, é aplicável quando a operação envolve o fornecimento de bens oriundos de fabricantes de diferentes países ou quando mais de um país contribui para a elaboração de um único bem exportado. Esse é o caso de bens e serviços de grande porte e maior complexidade, como ocorre no setor de aeronaves, embarcações ou petróleo e gás. Diversos exemplos de situações de exportação que envolvem 
entre as agências públicas de financiamento com as instituições financeiras privadas do próprio país (CATERMOL, 2008). A integração com outras fontes financiadoras poderia promover a ampliação do escopo de atuação do sistema de financiamento às exportações, bem como aumentar a disponibilidade de recursos para o exportador brasileiro. No Brasil, essa falta de integração limita o acesso das empresas a recursos financeiros, colocando o país em situação de desvantagem em relação a seus competidores internacionais. A esse respeito, Avila, Catermol e Dias (2015, p. 33) afirmam que

Para as instituições do governo brasileiro dedicadas a apoiar o
comércio exterior, torna-se desafiador acompanhar as inovações
introduzidas pela indústria financeira internacional, a partir do
reconhecimento da necessidade de ampliar a flexibilidade de seus
produtos, procedimentos e práticas em prol da composição de
diferentes fontes de recursos e do compartilhamento das
responsabilidades das entidades tomadoras de risco.

Souza e Barral (2015) afirmam que o sistema de crédito público brasileiro não acompanha a agressividade das agências de crédito à exportação em outros países, permitindo que outros países em desenvolvimento, como China, Coreia e Índia se tornem muito mais competitivos do que o Brasil nessa seara.

$O$ fato de o financiamento às exportações no Brasil ser relativamente menos competitivo do que em outros países tem impacto ainda mais notório para as atividades de empresas multinacionais. Diferentemente das empresas brasileiras, que não tem outra opção senão exportar a partir do Brasil, as multinacionais, muitas vezes, têm a possibilidade de eleger a partir de qual país realizar suas exportações, e um dos fatores levados em consideração são certamente as condições de financiamento disponibilizadas em cada mercado. Segundo Souza e Barral (2015), o Brasil atualmente não é considerado um low cost country pelas empresas multinacionais em termos de financiamento para o comércio exterior.

Às críticas estruturais sobre o sistema de crédito público à exportação no Brasil somam-se as dificuldades de natureza conjuntural. A crise econômica e os problemas fiscais do Estado brasileiro estão provocando, por exemplo, prejuízos às operações do PROEX-Equalização. Segundo Fonseca (2015), até 2013, o regime vinha funcionando com regularidade e pontualidade na viabilização dos recursos aos agentes financeiros

produtos e serviços produzidos por mais de um país podem ser verificados em Avila, Catermol e Dias (2015). 
executores do programa, proporcionando segurança aos agentes econômicos. Contudo, a partir de 2014, viriam ocorrendo atrasos na disponibilização das NTN-I aos agentes financeiros, desestimulando-os a realizar novas equalizações e caracterizando "um verdadeiro default do Tesouro Nacional junto às instituições financeiras nacionais e estrangeiras integrantes do PROEX" (FONSECA, 2015, p. 41).

Para agravar a situação, entre o final de 2014 e meados de 2015, houve uma suspensão das operações de financiamento do PROEX, prejudicando a inserção das empresas brasileiras no mercado internacional e acarretando ainda mais insegurança jurídica em relação aos instrumentos de crédito público. Conforme informado por técnicos do MDIC, os motivos para a paralização foram o esgotamento dos recursos do programa em 2014 e a demora na autorização para o Banco do Brasil executar o programa em 2015, esta última provocada por uma controvérsia no âmbito do governo quanto ao alcance da política comercial nacional, tendo em vista a crise fiscal. As operações do PROEX só voltaram à normalidade no segundo semestre de 2015 , o que levou a não utilização da totalidade dos recursos destinados ao programa nesse ano.

Apesar de todos os problemas associados às características as oferta de crédito, o que vem ocorrendo no Brasil nos últimos anos é uma redução significativa na demanda por operações de financiamento à exportação (vide gráficos do BNDES). Segundo informação de técnicos do MDIC, tanto o BNDES quanto o PROEX estariam em condições de atender totalmente a demanda atual por crédito, demonstrando que não existiria problema quantitativo no volume atual de oferta de crédito. O mais provável é que essa queda na demanda esteja associada à crise econômica do país atualmente, a qual gera impactos negativos para a atividade produtiva como um todo ${ }^{52}$. Esse resultado, contudo, é contra intuitivo, pois seria de se esperar que, em um cenário de crise do mercado interno associada à desvalorização cambial real, as empresas

52 Especificamente com relação às empresas de grande porte, um motivo aventado para o declínio dos financiamentos das exportação são os efeitos colaterais da Operação Lava Jato, que teria provocado a redução dos financiamentos para as empresas construtoras envolvidas na investigação de corrupção que vem sendo realizada pela polícia federal - os valores de desembolsos para o setor de construção, crescentes até 2014, caíram de 10,3 bilhões de reais nesse ano para cerca de 6 bilhões de reais em 2015 (uma queda de aproximadamente 40\%). Não obstante, os dispêndios do BNDES com o setor de construção representam em torno de apenas $5 \%$ dos desembolsos totais, de modo que o impacto desse último fator certamente não é o mais significativo para a abrupta queda dos financiamentos do BNDES no último ano. (Os dados de desembolso do BNDES por atividade econômica e a participação de cada setor nos desembolsos totais podem ser verificados no sítio eletrônico do site, pelo endereço <http://www.bndes.gov.br/SiteBNDES/bndes/bndes_pt/Institucional/BNDES_Transparente/Estati sticas_Operacionais/painel3_setorial.html>). 
brasileiras buscassem ainda mais o redirecionamento de sua produção para o mercado externo.

Verifica-se, portanto, que as agências de crédito à exportação no Brasil desempenham o importante papel de atuar em nichos de mercado não cobertos pela atividade privada. No entanto, existe ainda certo desconhecimento das empresas em relação ao funcionamento dos mecanismos de crédito público, o que, somado às dificuldades operacionais, limita a utilização dessas fontes de financiamento. Do crédito utilizado, nota-se uma importante concentração em um número pequeno de empresas de grande porte, o que impõe um questionamento quanto à efetividade dos instrumentos em relação ao objetivo pretendido de promover a internacionalização de empresas brasileiras.

A redução na utilização de recursos de crédito público nos últimos anos (tanto do PROEX quanto do BNDES), por motivos diversos de oferta e de demanda, demonstra que está havendo uma redução na promoção da atividade exportadora por meio desses mecanismos. Essa constatação impõe a necessidade de que análises mais aprofundadas sejam realizadas, a fim de identificar com mais precisão as causas do fenômeno e possíveis mecanismos de mitigação. Entre esses mecanismos, poderiam ser consideradas as sugestões de especialistas de promover maior integração das agências de crédito público com outros agentes financeiros públicos e privados, de modo a ampliar a disponibilidade e a competitividade dos instrumentos de financiamento e garantia às exportações para as empresas brasileiras, sobretudo neste momento de crise econômica e de restrição na disponibilidade de recursos financeiros do governo. 


\section{CONCLUSÃO}

As instituições são importantes determinantes para o desempenho da economia e do comércio exterior de um país, pois são capazes de orientar o comportamento dos agentes por meio de incentivos positivos ou negativos que fornecem em relação a determinados comportamentos. Sob essa ótica, o Estado ganha papel relevante na condução do comércio internacional, já que é o grande responsável pela construção das instituições formais que disciplinam a atividade econômica.

O Estado, contudo, não dispõe de plena autonomia sobre todos os aspectos institucionais que afetam o comércio exterior do país, na medida em que é limitado pelos compromissos internacionais estabelecidos no âmbito do regime internacional de comércio. Esses acordos internacionais de comércio podem ser de natureza multilateral ou regional. Se, por um lado, os acordos são positivos no sentido de tentar promover o crescimento dos fluxos comerciais internacionais e de deixar claras as regras do jogo entre os países; por outro, restringem a autonomia do Estado para estabelecer políticas de comércio exterior e normatizar a atividade comercial. Essa perda de autonomia nem sempre é negativa, mas torna-se problemática quando as instituições internacionais que normatizam a matéria não funcionam adequadamente.

O processo de construção e mudança institucional é complexo e possui um caráter path dependent, que significa que as instituições são decorrentes de um processo histórico de formação e de decisões tomadas no passado e determinaram sua trajetória de evolução. Por isso, as instituições possuem um caráter permanente, mas não imutável. Nos países menos desenvolvidos, a mudança institucional esbarra em dificuldades associadas às características culturais da sociedade que refletem negativamente sobre as instituições. Apesar desse diagnóstico, não é conveniente tentar "importar" instituições de países desenvolvidos, pois as instituições têm impactos diferentes em ambientes diversos.

O aperfeiçoamento das instituições de um país, portanto, é um processo muito particular e que está associado às suas características sociais, culturais e históricas. Por isso, antes de propor fórmulas de mudança institucional, é preciso compreender as características do objeto que se deseja alterar, de sua história e de seu ambiente. Nesse sentido, este trabalho foi desenvolvido como um estudo de caso sobre as instituições e o comércio internacional do Brasil, com a finalidade de proporcionar uma visão abrangente sobre seu histórico de constituição, as relações com o regime 
internacional de comércio, suas características atuais e as principais dificuldades decorrentes dessas características. Não sendo possível tratar de todos os aspectos institucionais associados ao comércio internacional brasileiro, foram eleitos três eixos considerados essenciais: as tarifas, os tributos e os mecanismos de crédito público.

Sobre a formação das instituições no Brasil verificou-se que os sucessivos governos ao longo do século XX procuraram avançar na consolidação das burocracias e no aperfeiçoamento normativo associados ao comércio exterior. De maneira geral, apesar de situações e medidas pontuais de retrocesso, pode-se dizer que houve evolução em termos de abertura comercial e liberalização das importações, emprego de instrumentos de financiamento e garantia às exportações, adoção de medidas e programas de desoneração tributária das exportações e aperfeiçoamento do aparelho burocrático e das ferramentas administrativas de comércio exterior. Apesar disso, nos últimos anos, houve uma retomada de estratégias mais defensivas e protecionistas de comércio exterior, que têm afetado a inserção brasileira no comércio internacional e cujos efeitos de longo prazo para a indústria nacional ainda não podem ser avaliados (mas não se pode descartar o risco de um balanço final negativo).

Além disso, constatou-se a ocorrência de sombreamentos de competências e de conflitos interburocráticos sobre os temas de comércio exterior, afetando a elaboração e a implementação de políticas. A própria CAMEX, instância máxima no disciplinamento do comércio exterior no Brasil, passou por períodos de avanços e recuos em termos de atuação e atribuições, e é vista como um órgão que necessita ser empoderado como foro de discussões estratégicas. Medidas nesse sentido foram recentemente tomadas pelo governo interino em exercício, sobre cujos resultados práticos ainda é cedo para se fazer uma avaliação. Fica demonstrado, não obstante, que o país ainda está em processo de definição do seu modelo de governança sobre o tema, e que as instituições estão longe de atingir a maturidade e a estabilidade.

O regime internacional de comércio é um fator determinante no processo de construção das instituições nacionais, na medida em que os compromissos assumidos por um país no plano internacional se impõem internamente e limitam sua autonomia normativa e para elaboração de políticas. O Brasil está inserido em dois sistemas de acordos internacionais em matéria comercial: o multilateral, representado pela OMC, e o regional, que consiste no MERCOSUL. Dentro da OMC, verificou-se que o sistema é composto por uma série de acordos, os quais, em decorrência da sistemática de negociação empregada na criação da organização, tiveram de ser adotados por todos 
os membros. Os acordos plurilaterais, aos quais os membros podem optar por aderir ou não, ocorrem de forma absolutamente excepcional. O Brasil, como membro da OMC, encontra-se sujeito a todos os acordos multilaterais, cujo descumprimento o sujeita a ser acionado no Sistema de Solução de Controvérsias e sofrer retaliação dos parceiros comerciais.

O MERCOSUL, na condição de acordo regional, está amparado por autorização do sistema multilateral de comércio e constitui-se num mecanismo de liberalização comercial complementar a esse sistema, e não contraditório com ele. Devido à condição de união aduaneira e à pretensão de constituir um mercado comum, o nível dos compromissos de liberalização tarifária e de convergência regulatória no âmbito do MERCOSUL é muito maior do que na OMC, e inclui a adoção de uma tarifa externa comum. A governança do bloco é realizada nos moldes intergovernamentais e compreende estruturas desde o nível absolutamente político, de Presidente da República, até os níveis mais técnicos, para tratar dos diversos temas da integração. Em todos os níveis, as decisões são tomadas por consenso, o que, em razão de inúmeras divergências entre os países, vem impondo muitas dificuldades ao avanço da integração intrabloco e ao aprofundamento das relações com terceiros países.

Dos aspectos institucionais do Brasil que analisamos com mais detalhe, 0 principal impactado pelos acordos internacionais são as tarifas. A existência de inúmeros mecanismos de exceção à TEC tornam a estrutura tarifária do bloco complexa e impedem que o MERCOSUL se constitua numa união aduaneira perfeita. As diferenças nos níveis de desenvolvimentos dos países e, por consequência, dos objetivos que cada um tem dentro do bloco, somado à sistemática de decisões consensuais, dificulta e retarda todos os tipos de deliberação a respeito de alterações tarifárias dentro do bloco. Além disso, os princípios que nortearam a definição das tarifas do bloco não restaram estabelecidos em nenhum instrumento normativo, o que deixa os pleitos de alterações tarifárias permanentes mais sujeitos a decisões políticas do que técnicas.

A morosidade e as incertezas associadas ao funcionamento da TEC acabam por prejudicar o planejamento das empresas, desestimulando suas decisões de investimentos, o que inevitavelmente afeta as possibilidades do país em termos de comércio exterior. Outro problema associado à questão tarifária do MERCOSUL está na normativa que determina que o tema seja sempre negociado com terceiros países de forma conjunta pelo bloco, o que vem dificultando a realização de acordos comerciais 
pelos países do bloco e os deixando à margem das iniciativas mais modernas de integração.

Os tributos são um aspecto institucional eminentemente de caráter doméstico, que têm impactos diretos sobre o desenvolvimento da atividades produtiva nacional e, consequentemente, de suas exportações. No Brasil, o sistema tributário é complexo e a carga tributária é considerada muito alta (comparativamente às condições de infraestrutura que o país oferece), o que é considerado um aspecto de custo Brasil que, da mesma forma que as tarifas, interfere nas decisões de investimentos produtivos no país. Além disso, o Brasil também sofre com a dificuldade de eliminação de resíduos tributários ao longo da cadeia produtiva, contaminando os produtos exportados com custos tributários e prejudicando sua competitividade no mercado externo.

Diversas iniciativas de desoneração tributária das exportações já foram adotadas pelo governo ao longo do tempo, incluindo um programa específico para eliminação de resíduos tributários, o Reintegra. As medidas, contudo, são consideradas insuficientes pelo setor produtivo, que se queixa do alcance das medidas e das dificuldades que são enfrentadas na recuperação dos créditos tributários gerados. Especificamente com relação ao Reintegra, um problema recente e que gerou muita sensibilização entre o meio empresarial foi a redução drástica no percentual de recuperação de crédito, em decorrência da crise econômica e das necessidade de aumento de arrecadação fiscal do governo.

Além de a carga tributária ter impactos diretos no custo do produto exportado, a falta de previsibilidade ocasionada pela instabilidade do sistema tributário brasileiro provoca um desestímulo ao desenvolvimento da atividade produtiva no país. E quanto menos produção nacional, menores as possibilidades de exportação. Trata-se de um problema, contudo, de difícil solução, pois esbarra em importantes conflitos interburocráticos e entre os próprios entes federados. A preocupação primeira do sistema tributário nacional é proporcionar arrecadação para o Estado, e existem tributos destinados à arrecadação para cada nível de ente da federação. Por isso, mudanças que visem a simplificação e redução de carga tributária encontram muita resistência tanto em nível de governo federal (sobretudo no âmbito do Ministério da Fazenda) quanto em nível de estados e municípios, tornando a tributação um aspecto temerário para a competitividade da indústria nacional.

Sobre o sistema brasileiro de financiamento de garantia às exportações, foi ressaltado que o crédito público é essencial em nichos de mercado não cobertos pelo 
setor financeiro privado, em decorrências dos prazos ou dos riscos envolvidos na operação. Por isso, não se pode prescindir da atuação do governo nesse setor. Os créditos públicos à exportação, contudo, tem de observar normativas internacionais para que não sejam considerados subsídios ilegais, conforme estabelecido no Acordo de Subsídios da OMC e em Decisão CMC do MERCOSUL. Nesse sentido, o Brasil busca observar parâmetros internacionais de operações de crédito público adotados por países da OCDE.

Constatou-se que o sistema público brasileiro é relativamente estruturado, contando com instrumentos do Banco do Brasil e do BNDES, e que vinha recebendo recursos crescentes do governo ao longo das últimas décadas. Sobre as garantias, destacou-se o papel do Fundo de Garantia à Exportação (FGE), nacional, e do Convênio de Pagamentos e Créditos Recíprocos (CCR), no âmbito da ALADI. Foram, contudo, constadas diversas críticas do setor privado com relação à operacionalidade desses instrumentos, especialmente com relação a acesso a informação, dificuldades burocráticas na utilização e não atendimento das necessidades do exportador. Com relação ao crédito utilizado, constatou-se grande concentração dos recursos no atendimento de grandes empresas, o que levanta questionamentos quanto à efetividade dos instrumentos em promover o aumento da inserção de empresas brasileiras no exterior. Outra crítica feita ao sistema é quanto à falta de integração com instrumentos crédito privado e com agências de crédito do exterior, o que poderia ampliar o leque de instrumentos financeiros para o exportador e reduzir o desembolso para o governo brasileiro. Além desses problemas estruturais, foram verificadas situações pontuais em que a disponibilidade de crédito público foi afetada por conflitos burocráticos quanto à definição da política comercial brasileira.

Apesar disso, nos últimos anos, não tem havido qualquer problema de escassez de crédito público no mercado brasileiro. Ao contrário, o que se tem verificado é uma redução expressiva na demanda por crédito à exportação, em decorrência da crise econômica por que vem passando o país e que vem afetando drasticamente o nível de produção das empresas. Trata-se, não obstante, de um fenômeno conjuntural, que deverá cessar tão logo haja recuperação da atividade econômica do país. Nesse momento, o sistema de crédito deverá estar preparado para atender aos exportadores brasileiros, por isso, os problemas estruturais devem ser objeto de preocupação desde já. 
Ficou, portanto, demonstrado que diversas dificuldades estão envolvidas na utilização dos instrumentos tarifário, tributário e financeiro como meios de promoção do comércio exterior brasileiro. Essas instituições encontram, hoje, limitações tanto no plano interno - econômico e político - quanto no regime internacional - que impedem a completa autonomia do país na sua utilização. Em vista disso, o Brasil tem envidado esforços no desenvolvimento e na utilização de meios alternativos para promoção do comércio exterior, entre os quais cabe destacar as iniciativas de cooperação regulatória, facilitação de comércio e facilitação de investimentos. Nesse sentido, o país vem acompanhando a agenda mais recente dos países desenvolvidos e da própria OMC.

Seria interessante que estudos futuros a respeito do tema pudessem analisar de que forma as novas frentes vêm se desenvolvendo e quais seus impactos para o comércio exterior brasileiro. É importante, contudo, que não se perca de vista os problemas associados às instituições tradicionais - os sistemas tarifário, tributário e de crédito público -, que se mantenha constante avaliação crítica sobre seu desempenho e que se busque, cada vez mais, torná-las instrumentos efetivos de fomento à atividade comercial. Para isso, é imprescindível a atuação do governo brasileiro, no seu papel de agente central na, construção institucional.

Por fim, cabe destacar que existe um fator extremamente relevante para as exportações brasileiras e que não foi objeto de análise neste trabalho: o próprio desenvolvimento da indústria nacional. Tratar dos problemas da indústria brasileira sem dúvidas exigiria um trabalho a parte, pois o tema é bastante importante e complexo. Apesar disso, não podemos negligenciá-lo, pois o desenvolvimento industrial também está associado a características institucionais do país. Segundo avaliado por Suzigan e Furtado (2010), os principais problemas associados à elaboração e à implementação de políticas industriais no país são a falta de atuação sistêmica dos órgãos competentes do governo, o anacronismo das estruturas burocráticas e normativas associadas às atividades industrial e tecnológica, a complexidade dos marcos regulatórios e dos instrumentos de política e a falta de capacitação específica dos quadros técnicos do governo que atuam na área. Note-se que, invariavelmente, todos esses problemas estão associados às instituições.

É preciso, portanto, suscitar a reflexão quanto à importância de se tratar a institucionalidade do comércio exterior brasileiro sob um enfoque mais amplo, incluindo não apenas as instituições diretamente associadas à atividade comercial, mas também aquelas que estão por trás do desenvolvimento industrial. De nada adianta simplificar o 
sistema tarifário, eliminar os resíduos tributários e aperfeiçoar os instrumentos de financiamento e garantia das exportações, se o produto brasileiro não for intrinsicamente competitivo. Mais do que olhar para o comércio, é preciso olhar para os problemas da indústria, questionar porque nosso produtos não são competitivos, porque estamos perdendo mercado, quais as falhas das nossas políticas industriais, e como o Estado pode, por meio das instituições, dar novas orientações ao setor industrial brasileiro, de modo a incentivá-lo no sentido da produtividade, da originalidade, da inovação tecnológica, da maior integração às cadeias globais de valor. 


\section{REFERÊNCIAS}

ANDERSON, James E. Why do nations trade (so little)? Boston College, 1999. Documento digital disponível em: <http://fmwww.bc.edu/EC-P/wp428.pdf>. Acesso em: 29/11/2015.

ANDERSON, James. E. Notes on international trade and institutions. [S.I], 2011. Documento digital disponível em <https://www2.bc.edu/ anderson/Institutions.pdf>. Acesso em: 12/04/2015.

AVILA, Henrique; CATERMOL, Fabricio; DIAS, Augusto. Financiamento ao comércio exterior: o desafio da inovação e implicações para o caso brasileiro. Revista Brasileira de Comércio Exterior. Ano XXIX, número 124, jul-set/2015. [S.I]: FUNCEX, 2015, pp. 18-35.

ASSAD JUNIOR, José Clemenceau; CARREIRO, Paulo Roberto. Financiamento ao comércio exterior no Brasil: perspectivas e desafios. Revista Brasileira de Comércio Exterior. Ano XXIX, número 124, jul-set/2015. [S.I]: FUNCEX, 2015, pp. 44-47.

BAPTISTA, Rosária Costa. MERCOSUL e a negociação da Tarifa Externa Comum (TEC). CEBRI Artigos. Vol. 4, ano V. [S.I]: [s.n.\}, 2010. Documento eletrônico disponível em < http://www.cebri.org/midia/documentos/cebri_artigo_mercosul_ok.pdf>. Acesso em: 03/05/2016.

BARRAL, Welber; BOHRER, Carolina P. A política comercial do governo Dillma Roussef: primeiras impressões. Política Externa. Vol. 20, n. 3., dez/2011-fev/2012. São Paulo: Ed. Paz e Terra, 2011.

BAUMANN, Renato. Befiex: efeitos internos de um incentivo à exportação. Revista Brasileira de Economia. Vol. 44. Rio de Janeiro: Fundação Getúlio Vargas, 1990, pp. 167-189.

BERNAL-MEZA, Raúl. América Latina en el mundo: el pensamiento latinoamericano y la teoria de relaciones internacionales. 1a ed. Buenos Aires: Grupo Editor Latinoamericano, 2005.

BONELLI, Regis et al. As políticas industrial e de comércio exterior no Brasil: rumos e indefinições. Texto para discussão $n^{\circ}$. 527. Rio de Janeiro: IPEA, 1997.

BRASIL. Decreto $n^{\circ}$. 53.889, de 29 de abril de 1964. Dispõe sobre a criação da Comissão de Comércio Exterior e dá outras providências. Disponível em < http://www2.camara.leg.br/legin/fed/decret/1960-1969/decreto-53899-29-abril-1964393860-publicacaooriginal-1-pe.html>. Acesso em: 10/02/16.

BRASIL. Lei. $\mathrm{n}^{\circ}$. 2.145, de 29 de dezembro de 1953. Cria a Carteira de Comércio Exterior. Dispões sobre o intercâmbio comercial com o exterior e dá outras providências. Disponível em < http://www.planalto.gov.br/ccivil_03/leis/L2145.htm>. Acesso em: 10/02/16. 
BRASIL. Lei $n^{\circ}$. 3.244, de 14 de agosto de 1957. Dispõe sobre a reforma da tarifa das alfândegas e dá outras providências. Disponível em < http://www.planalto.gov.br/CCIVIL_03/leis/L3244.htm>. Acesso em: 10/02/2016.

BRASIL. Plano Nacional de Exportação. Brasília, DF, 24 de julho de 2015. Documento disponível em: <http://www.mdic.gov.br/arquivos/dwnl_1435244583.pdf>. Acesso em: $16 / 11 / 2015$.

BRASIL. Presidente (Fernando Henrique Cardoso). Mensagem ao Congresso Nacional. Brasília: Presidência da República, Secretaria de Comunicação Social, 1995.

BRASIL. Presidente (Fernando Henrique Cardoso). Mensagem ao Congresso Nacional. Brasília: Presidência da República, Secretaria de Comunicação Social, 1996.

BRASIL. Presidente (Fernando Henrique Cardoso). Mensagem ao Congresso Nacional. Brasília: Presidência da República, Secretaria de Comunicação Social, 1997.

BRASIL. Presidente (Fernando Henrique Cardoso). Mensagem ao Congresso Nacional. Brasília: Presidência da República, Secretaria de Comunicação Social, 1998.

BRASIL. Presidente (Fernando Henrique Cardoso). Mensagem ao Congresso Nacional. Brasília: Presidência da República, Secretaria de Comunicação de Governo, 1999.

BRASIL. Presidente (Fernando Henrique Cardoso). Mensagem ao Congresso Nacional. Brasília: Presidência da República, Secretaria de Comunicação de Governo, 2000.

BRASIL. Presidente (Fernando Henrique Cardoso). Mensagem ao Congresso Nacional. Brasília: Presidência da República, Secretaria de Comunicação de Governo, 2001.

BRASIL. Presidente (Fernando Henrique Cardoso). Mensagem ao Congresso Nacional. Brasília: Presidência da República, Secretaria de Comunicação de Governo, 2002.

BRASIL. Presidente (Luiz Inácio Lula da Silva). Mensagem ao Congresso Nacional. Brasília: Presidência da República, Secretaria de Comunicação de Governo e Gestão Estratégica, 2003.

BRASIL. Presidente (Luiz Inácio Lula da Silva). Mensagem ao Congresso Nacional. Brasília: Presidência da República, Secretaria de Comunicação de Governo e Gestão Estratégica, 2004.

BRASIL. Presidente (Luiz Inácio Lula da Silva). Mensagem ao Congresso Nacional. Brasília: Presidência da República, Secretaria de Comunicação de Governo e Gestão Estratégica, 2005.

BRASIL. Presidente (Luiz Inácio Lula da Silva). Mensagem ao Congresso Nacional. Brasília: Presidência da República, Secretaria-Geral da Presidência da República, 2006. 
BRASIL. Presidente (Luiz Inácio Lula da Silva). Mensagem ao Congresso Nacional. Brasília: Presidência da República, Secretaria-Geral da Presidência da República, 2007.

BRASIL. Presidente (Luiz Inácio Lula da Silva). Mensagem ao Congresso Nacional. Brasília: Presidência da República, Secretaria-Geral da Presidência da República, 2008.

BRASIL. Presidente (Luiz Inácio Lula da Silva). Mensagem ao Congresso Nacional. Brasília: Presidência da República, Secretaria-Geral da Presidência da República, 2009.

BRASIL. Presidente (Luiz Inácio Lula da Silva). Mensagem ao Congresso Nacional. Brasília: Presidência da República, Secretaria-Geral da Presidência da República, 2010.

BRASIL. Presidente (Dilma Rousseff). Mensagem ao Congresso Nacional. Brasília: Presidência da República, 2012.

BRASIL. Presidente (Dilma Rousseff). Mensagem ao Congresso Nacional. Brasília: Presidência da República, 2013.

BRASIL. Presidente (Dilma Rousseff). Mensagem ao Congresso Nacional. Brasília: Presidência da República, 2014.

BRASIL. Presidente (Dilma Rousseff). Mensagem ao Congresso Nacional. Brasília: Presidência da República, 2015.

BRESSER-PEREIRA, Luiz Carlos. Crescimento e desenvolvimento econômico. [S.I]: [s.n.], 2008. Notas para uso em curso de desenvolvimento econômico na Escola de Economia de São Paulo da Fundação Getúlio Vargas. Documento disponível em: < http://www.bresserpereira.org.br/Papers/2007/07.22.CrescimentoDesenvolvimento.Junh 019.2008.pdf>. Acesso em: 30/10/2015.

CATERMOL, Fabrício. Agências de crédito à exportação: o papel das instituições oficiais de apoio à inserção internacional das empresas. Revista do BNDES. V. 15, n. 30. Rio de Janeiro: BNDES, 2008, pp. 5-38.

CHANG, Ha-Joon. [2002]. Chutando a escada - a estratégia do desenvolvimento em perspectiva histórica. São Paulo: Editora UNISP, 2004.

CHAN, Ha-Joon; EVANS, Peter. The role of institutions in economic change. In: DYMSKI, Gary; DE PAULA, Silvana (Org.). Reimagining growth: institutions, development and society. Londres e Nova lorque: Zed Book, 2005, cap. 5.

CHANG, Ha-Joon. Institutional change and economic development: an introduction. In: CHANG, Ha-Joon (Org.). Institutional change and economic development. New York: United Nations University Press, 2007, cap. 1.

CHANG, Ha-Joon. Understanding the relationship between institutions and economic development - some key theoretical issues. In: CHANG, Ha-Joon (Org.). Institutional change and economic development. New York: United Nations University Press, 2007, cap. 2. 
COASE, Ronald $\mathrm{H}$. The problem of social cost. Journal of law and economics. Vol. 3. Chicago: The University of Chicago Press, 1960, pp.1-44.

CONFEDERAÇÃO Nacional da Indústria $(\mathrm{CNI})$. Entraves às exportações brasileiras. Brasília: CNI, 2014.

DARÓS, Lucia. Iniciativas de convergência regulatória. Seminário de barreiras técnicas ao comércio exterior. Apresentação em slides disponível em $<$ https://www.google.com.br/url?sa=t\&rct=j\&q=\&esrc=s\&source=web\&cd=2\&ved=0ahUK EwiFhNSljM3MAhWBwiYKHefsBjoQFggiMAE\&url=http\%3A\%2F\%2Fwww.firjan.com.br \%2Flumis\%2Fportal\%2Ffile\%2FfileDownload.jsp\%3Ffileld\%3D2C908A8A53C4BB8E01 541598726D7249\&usg=AFQjCNFsyJ6h7bnJWoAXDKWXw83aDIrXyw\&sig2=MwCDelJz RhuDQAqlsxFGRQ\&cad=rja>. Acesso em 09/05/2016.

DENIS, Henri. História do pensamento econômico. $8^{a}$ ed. Lisboa: Livros Horizonte, 2000.

DO, Quy-Toan; LEVCHENKO, Andrei A. Trade, inequality and political economy of institutions. IMF working paper, 2006. Documento digital disponível em <http://alevchenko.com/wp0656.pdf>. Acesso em: 22/02/2015.

EVANS, Peter. Interdisciplinary approaches to development: the 'institutional turn'. In: DUTT, A. K.; ROS, J. (Org.). International handbook of development economics. Vol. 1. Cheltenham: Edward Elgar Publishing Limited, 2008, cap. 5.

FERREIRA JUNIOR, Lier Pires. Estado, globalização e Integração regional: políticas exteriores de desenvolvimento e inserção internacional da AméricaLatina no final do século XX. Rio de Janeiro: América Jurídica, 2003.

FERNANDES, Ivan F. A. L. Burocracia e política: a construção institucional da política comercial brasileira pós abertura econômica. Dissertação de Mestrado do Departamento de Ciência Política da Faculdade de Filosofia, Letras e Ciências Humanas da Universidade de São Paulo. São Paulo: 2010.

FONSECA, Roberto Giannetti da. O papel do financiamento às exportações na promoção do comércio exterior brasileiro. Revista Brasileira de Comércio Exterior. Ano XXIX, número 124, jul-set/2015. [S.I]: FUNCEX, 2015, pp. 36-43.

FURTADO, Celso. A economia latino-americana. $4^{\mathrm{a}}$ ed. São Paulo: Companhia das Letras, 2007.

FURTADO, Celso. Raízes do subdesenvolvimento. $2^{a}$ ed. Rio de Janeiro: Civilização Brasileira, 2011.

GALA, Paulo. A teoria institucional de Douglas North. Revista de Economia Política. Vol. 23, n. 2 (90), abril-junho/2003. São Paulo: Editora 34, 2003, pp. 89-105.

GALVÃO, Marcos; ABREU, Márcia Donner; PIMENTEL, Fernando Meirelles. O Relançamento das Negociações da Rodada Doha. Revista Brasileira de Comércio Exterior. Ano XXIX, número 122, jan-mas/2015. [S.I]: FUNCEX, 2015, pp. 6-12. 
GILPIN, Robert. Global Political Economy: understanding the international economic order. Princeton: Princeton University Press, 2001.

GREMAUD, Amaury Patrick; VASCONCELLOS, Marco Antonio Sandoval de; TONETO JR., Rudinei. Economia Brasileira Contemporânea. $7^{\text {a }}$ ed. São Paulo: Atlas, 2007, cap. 14.

HARBER, Stephen (org.). Political institutions and economic growth in Latin America: essays in policy, history, and political economy. [S.I.]: Hoover Institution Press Publication, 2000.

HERMANN, Jennifer. Auge e declínio do modelo de crescimento com endividamento: o II PND e a crise da dívida externa. In: GIAMBIAGI, Fabio; VILLELA, André (org.). Economia brasileira contemporânea (1945-2004). Rio de Janeiro, Elsevier, 2005, cap. 4.

JAMESON, Kenneth P. Institutionalist development economics. In: DUTT, A. K.; ROS, J. (Org.). International handbook of development economics. Vol. 1. Cheltenham: Edward Elgar Publishing Limited, 2008, cap. 12.

KRASNER, Stephen D. Structural causes and regime consequences: regimes as intervening variables. In: KRASNER, Stephen D. (Org.). International regimes. New York: Cornell University Press, 1983, p. 1-21.

KUME, Honorio; PIANI, Guida; SOUZA, Carlos Frederico Bráz de. A política brasileira de importação no período 1987-1998: descrição e avaliação. [S.I.]: IPEA, 2003.

Documento disponível em:

<http://ipea.gov.br/agencia/images/stories/PDFs/livros/Capitulo_1_politica.pdf>. Acesso em: 28/02/2016.

LINDERS, Gert-Jan M. The effect of domestic institutions on international trade. Amsterdam, 2004. Documento digital disponível em <http://www-sre.wuwien.ac.at/ersa/ersaconfs/ersa04/PDF/357.pdf>. Acesso em: 12/04/2015.

LIPSON, Charles. The transformation of trade: the sources and effects of regime change. International Organization. Vol. 36, n. 2. Cambridge: MIT Press, 1982, pp. 417-455. Documento digital disponível em <http://www.jstor.org/stable/2706528>. Acesso em 05/03/16.

LIST, Friedrich. [1841]. The national system of political economy. Indianapolis: The Online Library of Liberty, 2011.

LUZ, Rodrigo. Relações econômicas internacionais: teoria e questões. $2^{a}$ ed. Rio de Janeiro: Elsevier, 2008.

MALAKET, Alexander R. O estado do comércio e o financiamento ao comércio: algumas observações. Revista Brasileira de Comércio Exterior. Ano XXIX, número 124, jul-set/2015. [S.I]: FUNCEX, 2015, pp. 8-17. 
MALTHUS, Thomas. [1798]. An essay on the principle of population. [S.I.]: Electronic Scholarly Publishing Project, 1998.

MANSFIELD. Edward D; REINHARDT. International institutions and the volatilty of international trade. International Organization. Vol. 62, n. 4. Cambridge: Cambridge University Press, 2008, pp. 621-652. Documento digital disponível em < http://www.jstor.org/stable/pdf/40071892.pdf>. Acesso em 01/04/2015.

MARX, Karl. [1867]. O capital. Edição resumida por Julian Borchardt. $7^{a}$ edição. Rio de Janeiro: LTC, 1982. Tradução de Ronaldo Alves Schimidt.

MELLO, Fernando Collor de. Mensagem ao Congresso Nacional. Brasília: Presidência da República, 1991.

MELLO, Fernando Collor de. Mensagem ao Congresso Nacional. Brasília: Presidência da República, 1992.

MINISTÉRIO do Desenvolvimento, indústria e Comércio Exterior. Financiamento e garantia às exportações: um guia rápido aos exportadores brasileiros. Brasília: [s.n.], 2015.

MORAES, Alexandre. Direito Constitucional. 10ª edição. São Paulo: Atlas, 2001.

NIOSI, Jorge; FAUCHER, Philippe. O Estado e o comércio internacional: tecnologia e competitividade. Revista de Economia Política. [S.I.], v. 10, $\mathrm{n}^{\circ} .1$, p. 91-110, 1990. Documento digital disponível em <http://www.rep.org.br/pdf/37-5.pdf>. Acesso em: 10/12/2014.

NORTH, Douglas. Institutions, institutional change and economic performance. Cambridge: Cambridge University Press, 1990.

NORTH, Douglas. Institutions. The Journal of Economic Perspectives. Vol. 5, n. 1, pp. 97-112. [S.I.]: American Economic Association, 1991.

NORTH, Douglas. [1993]. Prize lecture. Nobel lectures, Economics 1991-1995. Singapore: Torsten Persson, World Scientific Publishing Co., 1997. Versão digital da palestra disponível em < http://www.nobelprize.org/nobel_prizes/economicsciences/laureates/1993/north-lecture.html> . Acesso em: 06/10/2015.

NORTH, Douglas. Institutions matter. 1994. Documento digital disponível em < https://ideas.repec.org/p/wpa/wuwpeh/9411004.html>. Acesso em: 25/01/2015.

NORTH, Douglas. Some fundamental puzzles in economic history/development. St. Louis: Washington University, 1995. Documento digital disponível em <http://econwpa.repec.org/eps/eh/papers/9509/9509001.pdf>. Acesso em: 14/09/2015.

NORTH, Douglas. Understanding the process of economic change. Princeton: Princeton University Press, 2005.

OLIVEIRA, Ivan Tiago Machado. A ordem econômico-comercial internacional: uma análise da evolução do sistema multilateral de comércio e da participação da diplomacia 
econômica brasileira no cenário mundial. Contexto Internacional. Rio de Janeiro: [s.n.], 2007. Vol. 29, nº. 2, pp. 217-272.

OLSON, Mancur. Power and prosperity: outgrowing communist and capitalist dictatorship. New York: Basic Books, 2000.

PINTO, M. A. C. et al. A equalização de taxa de juros como instrumento de promoção das exportações brasileiras de bens de capital no período 1994-2005. BNDES, fev. 2008.

Disponível em:

<http://www.bndes.gov.br/SiteBNDES/bndes/bndes_pt/Institucional/Publicacoes/Consult a_Expressa/Setor/Exportacao/200802_2.html>. Acesso em 02 nov. 2014.

PORTELA, Paulo Henrique Gonçalves. Direito Internacional Público e Privado. $5^{\text {a }}$ edição. Salvador: Ed. Jus Podivm, 2013.

PRAZERES, Tatiana Lacerda. A OMC e os blocos regionais. São Paulo: Aduaneiras, 2008.

RAFFER, Kunibert. International institutions and development. In: DUTT, A. K.; ROS, J. (Org.). International handbook of development economics. Vol. 2. Cheltenham: Edward Elgar Publishing Limited, 2008, cap. 45.

RAMANZINI JÚNIOR, Haroldo. Parcerias estratégicas do Brasil no contexto do multilateralismo comercial. In: LESSA, Antônio Carlos; OLIVEIRA, Henrique Altemani (Org.). Parcerias estratégicas do Brasil: a dimensão multilateral e as parcerias emergentes. Vol. II. Belo Horizonte: Fino Traço, 2013. Cap. 6.

RICARDO, David. [1817]. On the principles of political economy and taxation. Ontario: Batoch Books, 2001.

RODRICK, Dani. The global governance of trade as if development really mattered. New York: United Nations Development Programme, 2001.

ROS, Jaime. Classical development theory. In: DUTT, A. K.; ROS, J. (Org.). International handbook of development economics. Vol. 1. Cheltenham: Edward Elgar Publishing Limited, 2008, cap. 8.

SALERNO, Mario Sergio; DAHER, Talita. Política Industrial, Tecnológica e de Comércio Exterior (PITCE): balanços e perspectivas. Brasília: [s.n], 2006. Disponível em <http://investimentos.mdic.gov.br/public/arquivo/arq1272980896.pdf>. Acesso em: 05/05/2016.

SANDRONI, Paulo. Novíssimo Dicionário de Economia. $10^{a}$ ed. São Paulo: Ed. Best Seller, 2002.

SMITH, Adam. [1776]. An Inquiry into the nature and causes of the wealth of nations.. Cambridge: The Electric Book Co, 1998. 
SOLOW, Robert M. A contrbution to the theory of economic growth. The Quarterly Journal of Economics. Vol 70, n. 1. Massachussetts: MIT Press, 1956.

SOUZA, Lúcia Helena; BARRAL, Welber. O financiamento à exportação como política econômica. Revista Brasileira de Comércio Exterior. Ano XXIX, número 124, julset/2015. [S.I]: FUNCEX, 2015, pp. 48-55.

SUZIGAN, Wilson; FURTADO, João. Instituições e políticas industriais e tecnológicas: reflexões a partir da experiência brasileira. Estudos Econômicos. Vol. 40, $n^{\circ}$. 1. São Paulo: FEA-USP, 2010, pp. 7-41.

THORSTENSEN, Vera. OMC - Organização Mundial do Comércio: as regras do comércio internacional e a nova rodada de negociações multilaterais. $2^{\mathrm{a}}$ edição. São Paulo: Aduaneira, 2003.

THORSTENSE, Vera; KOTZIAS, Fernanda. Integração regulatória: uma proposta de coerência, convergência e cooperação para modernização do MERCOSUL. Boletim de Economia e Política Internacional - BEPI. N . 20, mai-ago/2015. Brasília: IPEA, 2015.

VAGGI, Gianni. Historical antecedents of development economics. In: DUTT, A. K.; ROS, J. (Org.). International handbook of development economics. Vol. 1. Cheltenham: Edward Elgar Publishing Limited, 2008, cap. 7.

VEBLEN, Thorstein. [1899]. The theory of the leisure class. Pennsylvania: The Pennsylvania State University, 2003. Electronic Classiscs Series.

VEIGA, Pedro da Motta; IGLESIAS, Roberto Magno. A institucionalidade da política brasileira de comércio exterior. Rio de Janeiro: BNDES, 2002. Disponível em: <http://www.bndes.gov.br/SiteBNDES/export/sites/default/bndes_pt/Galerias/Arquivos/c onhecimento/livro_desafio/Relatorio-03.pdf>. Acesso em 01/08/2015.

VEIGA, Pedro da Motta; RIOS, Sandra Polónia. 25 anos de política comercial no Brasil. Revista Brasileira de Comércio Exterior. Vol. 100. Rio de Janeiro: Fundação Centro de Estudos do Comércio Exterior - FUNCEX, 2009.

VEIGA, Pedro da Motta; RIOS, Sandra Polónia; NAIDIN, Leane Cornet. A hiperatividade política comercial e industrial do primeiro biênio Dilma. Pontes. Vol. 9, $\mathrm{n}^{\circ}$. 6. International Centre for Trade and Sustainable Development: Genebra, 2013.

VIANNA, Sérgio Besserman; Villela, André. O pós-guerra (1945-1955). In: VILLELA, André; GIAMBIAGI, Fabio. Economia brasileira contemporânea (1945-2004). Rio de Janeiro: Elsevier, 2005, cap. 1.

VIGEVANI, Tulio; MARIANO, Marcelo Passini; MENDES, Ricardo Glöe. Instituições e conflitos comerciais no Mercosul. São Paulo em Perspectiva. $N^{\circ}$. 16 (1), pp. 44-53. [S.I]: [s.n.]: 2002.

WEINGAST, Barry R. The economic role of political institutions: market-preserving federalism and economic development. [S.I.]: Oxford University Press, 1995. 
WILLIAMSON, Oliver E. The economic institutions of capitalism: firms, markets, relational contracting. [S.I.]: The Free Press, 1985.

WORLD Trade Organization. Understanding the WTO. WTO: Genebra, 2015. $5^{\text {a }}$

edição. Disponível em: <https://www.wto.org/english/thewto_e/whatis_e/tif_e/tif_e.htm>. Acesso em 30/03/2016. 